Georgetown University Law Center

Scholarship @ GEORGETOWN LAW

2014

\title{
Representation in Context: Party Power and Lawyer Expertise
}

Colleen F. Shanahan

Georgetown University Law Center, cfs32@law.georgetown.edu

Anna E. Carpenter

University of Tulsa College of Law.

Alyx Mark

George Washington University

This paper can be downloaded free of charge from:

https://scholarship.law.georgetown.edu/facpub/1368

http://ssrn.com/abstract=2479857

This open-access article is brought to you by the Georgetown Law Library. Posted with permission of the author. Follow this and additional works at: https://scholarship.law.georgetown.edu/facpub

Part of the Civil Law Commons, Constitutional Law Commons, Legal History Commons, and the Litigation Commons 


\title{
Representation in Context: Party Power and Lawyer Expertise
}

\author{
Colleen F. Shanahan, Anna E. Carpenter, and Alyx Mark*
}

The questions when, why, and how legal representation makes a difference for parties in civil litigation remain largely unanswered, although recent scholarship raises compelling new questions and suggests new explanations and theoretical approaches. Understanding how legal representation operates, we argue, requires an appreciation for the context in which the representation actually takes place. This article examines two previously unexplored elements of the context of legal representation through empirical and theoretical analysis: the balance of power between the parties to a dispute and the professional, specifically strategic, expertise that a legal representative contributes. The results of a study of 1,700 unemployment compensation cases in the District of Columbia's central administrative court reveal two key findings. First, represented parties have better case outcomes than unrepresented parties, though employers - the more powerful party to a dispute or the quintessential "haves" - see less benefit from legal representation than claimants - the less powerful party or the "have nots." Second, represented parties are more likely to use procedures than unrepresented parties. Yet, surprisingly, represented claimants who use certain evidentiary procedures have worse case outcomes than represented claimants who do not use those same procedures. Thus, in attempting to answer the question of when, why, and how legal representation makes a difference, we argue that it depends on who the represented party is, who they are up against, and the expertise the representative brings.

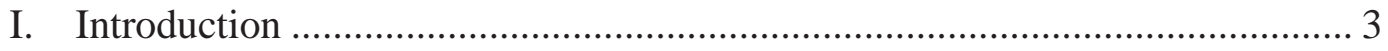

II. Previous Studies and Theories of Representation ..................................... 7

A. Previous Empirical Studies ................................................................ 7

B. Existing Theories of Power and Expertise .......................................... 11

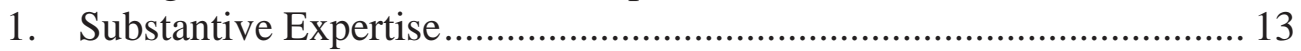

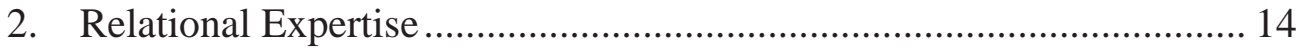

3. Non-lawyers' Use of Professional Expertise .................................... 15

\footnotetext{
* Colleen F. Shanahan is Visiting Associate Professor of Law and Director, The Community Justice Project, at Georgetown University Law Center. Anna E. Carpenter is Assistant Clinical Professor of Law and Director, Lobeck Taylor Family Advocacy Clinic, at University of Tulsa College of Law. Alyx Mark is a Ph.D. candidate in American Politics/Methodology at The George Washington University. For comments and ideas, we thank the participants in the Bellow Scholars Workshop, Clinical Law Review Workshop, Georgetown Junior Faculty Workshop, Oklahoma Junior Faculty Workshop, AU Poverty Law Conference Panel, Madison Access to Justice Workshop, AALS Clinical Conference Workshop, and the Law and Society Annual Meeting. We thank Jane Aiken, Juliet Aiken, Catherine Albiston, Benjamin Barton, Tonya Brito, Juliet Brodie, Michael Fischer, Geoffrey Heeren, Faith Mullen, Victor Quintanilla, Mitt Regan, Tanina Rostain, Rebecca Sandefur, Jeff Selbin, Jessica Steinberg, Joshua Teitelbaum, Steven Wizner, and Stefanie Wong for their comments on various drafts of this article. For expert research assistance, we thank Jamie Bowers, Claudine Brenner, Hannah Guerrier, Madelaine Harrington, Katrina Homel, Michael J. Nelson II, Brice Plebani, Meredith Ragany, Rohini Singh, Samantha Wiggins, Emily Wong, Alyssa Wootton, and Iris Xie. For their support of this project, we thank Gregory Klass, Morgan Stoddard, the Georgetown Law Library, the Georgetown Summer Faculty Fund, and the University of Tulsa Faculty Development Summer Fellowship. Finally, we thank Judge Steven Wellner and the staff of the D.C. Office of Administrative Hearings for their support of this project and our research team.
} 


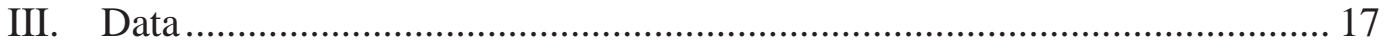

A. The Site of the Study.......................................................................... 20

1. Unemployment Insurance Program ..................................................... 20

2. Unemployment Insurance Law in the District ...................................... 22

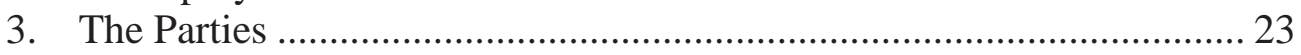

4. The Representatives ........................................................................... 25

5. Hearing Process and Procedure ………………................................... 27

a. Burdens of Proof .......................................................................... 30

b. Evidence Disclosures ........................................................................ 34

B. Representation and Outcomes Across Studies ............................................ 36

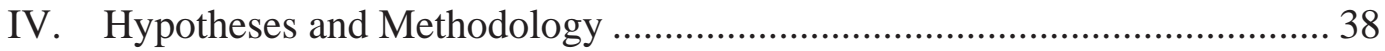

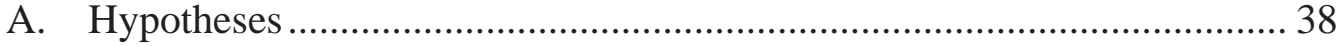

1. Representation and Balance of Power ………………......................... 38

a. Appearance of Representative............................................................... 39

2. Representation and Strategic Expertise …………................................. 40

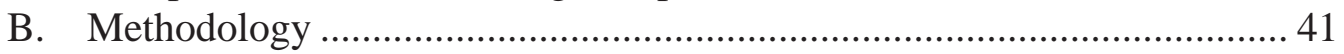

1. Dependent Variables: Case and Procedural Outcomes............................ 43

2. Independent Variables: Representation and Balance of Representation 45

3. Independent Variable: Representative Appearance at Hearing .............. 46

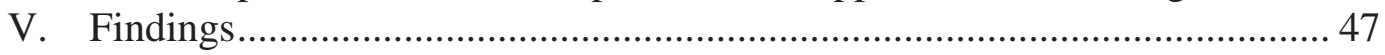

A. Representation and Balance of Power ..................................................... 47

B. Representation and Strategic Expertise ....................................................5 50

1. Party Appearance at Hearing …………………............................... 51

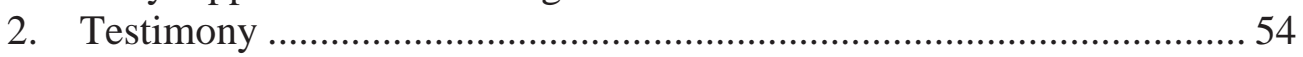

3. Document Disclosure .......................................................................... 57

4. Introduction of Documents .................................................................. 59

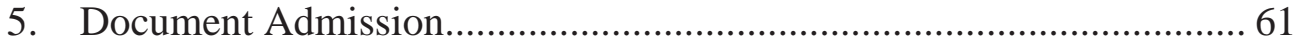

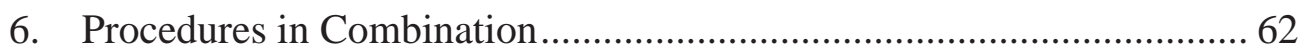

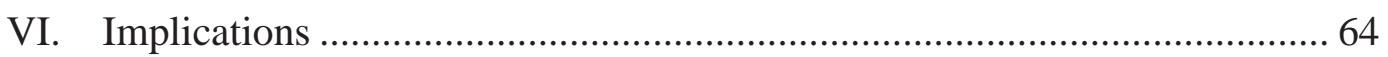

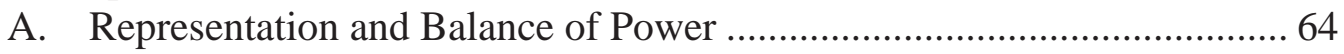

B. Representation, Use of Procedures, and Strategic Expertise ..................... 71

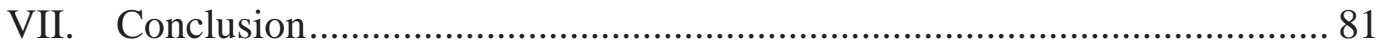

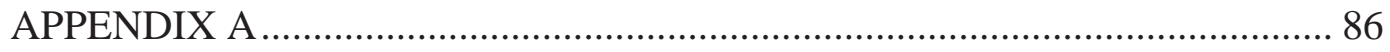




\section{Introduction}

Advocacy, scholarship, and court action are currently focused on critical needs in civil representation in the United States. Despite this focus, we are still unable to answer a fundamental question: when do civil litigants need a lawyer to effectively participate in our justice system $?^{1}$ In part, this ongoing quest is the result of the incomplete development of empirical research—much existing research is focused on the outcome of cases with little exploration of how those outcomes are reached. And in equal part, this quest continues because we have not yet fully developed theories that explain the effectiveness of representation. ${ }^{2}$ This article attempts to provide both theoretical grounding and empirical analysis of when, why, and how representation matters. We believe these core questions can only be understood - and we can only make good legal and policy decisions about when civil litigants should have lawyers - by investigating legal representation in context. We begin to engage in the complexity of studying representation in context by moving beyond the question of whether a litigant wins when she has a lawyer. To do this, we investigate how the balance of power between the parties interacts with representation and ask exactly what expertise a lawyer lends to the civil litigation process.

\footnotetext{
${ }^{1}$ See Catherine Albiston \& Rebecca L. Sandefur, Expanding the Empirical Study of Access to Justice, 2013 Wis. L. Rev. 101, 106 (2013); Jeffrey Charn \& Jeffrey Selbin, The Clinic Lab Office, 2013 WIS. L. REV. 145, 159-161 (2013); D. James Greiner \& Cassandra Wolos Pattanayak, Randomized Evaluation in Legal Assistance: What Difference Does Representation (Offer and Actual Use) Make?, 121 YALE L.J. 2118, 2125-26 (2012); Jeffrey Selbin, Jeanne Charn, Anthony Alfieri \& Stephen Wizner, Service Delivery, Resource Allocation, and Access to Justice: Greiner and Pattanayak and the Research Imperative, 122 YALE L.J. ONLINE 45, 54 (2012).

${ }^{2}$ See generally Albiston \& Sandefur, supra note 1 (offering an access to justice research agenda that is theory-driven and explores a broad range of issues related to civil justice); Joshua B. Fischman, Reuniting "Is" and "Ought” in Empirical Legal Scholarship, 162 U. PA. L. REV. 117, 121 (2013) (calling for legal scholars to develop and be explicit about normative goals in empirical research and noting that "intuition alone cannot suffice to relate observable data to normative claims; legal scholarship needs conceptual frameworks and empirical methods that can bridge the gap between 'is' and 'ought"').
} 
The site of the study is an administrative court where judges hold de novo hearings to resolve legal disputes between two parties, claimants seeking unemployment benefits and employers opposing the grant of unemployment benefits. The units of observation are cases, all of which have the potential to end in a hearing and most of which do end in this way. Thus, like much of the access to justice literature, this study is concerned with legal disputes that are formally adjudicated. ${ }^{3}$ These hearings are a particularly good context for examining the complexity of the value of representation because they have clear, binary outcomes, a variety of parties and representatives, and a relatively formal legal process with clear procedural steps. ${ }^{4}$

This article relies on a data set of 1,794 unique cases. The data encompass all unemployment benefit appeals in the District of Columbia in 2012 where the circumstances of separation are at issue, regardless of which parties appeared at the hearing. The data for each case includes extensive coding regarding the circumstances and activities in the case, including the fact and type of representation, the presence of a representative at the hearing, the presence of parties at the hearing, the participation of parties in different procedural steps of the hearing process, and the procedural and

\footnotetext{
${ }^{3}$ Most empirical studies on access to justice focus on civil justice problems that actually reach a lawyer's attention and become formal cases in the justice system, a focus that Albiston and Sandefur have challenged because it leaves out the vast majority of civil justice problems that never actually come to the attention of a lawyer, let alone an adjudicator. See Albiston \& Sandefur, supra note 1, at 109.

${ }^{4}$ It is common, when writing about administrative hearings, for scholars and policy-makers to assert that the quasi-inquisitorial nature of these hearings, where many parties are pro se, representation is rare, and the rules of evidence and procedure are relaxed, is a departure from the regular operation of civil courts. See Greiner \& Pattanayak, supra note 1, at 2137. It might be suggested that the applicability of a study such as this is limited given the differences between administrative hearings and city and county civil courts. However, the reality of the day-to-day operations of our civil justice system suggests this claim is overstated. The vast majority of litigants in civil cases are unrepresented and even a brief observation at any of our nation's workhorse civil courts will reveal that hearings in these settings are often no less inquisitorial in nature, the rules of evidence and procedure are similarly relaxed (or ignored), and representation is incredibly rare. Although the structure, and perhaps the dream, of the adversarial system are more visible in our civil justice system, it is certainly not the case that inquisitorial judging is a rarity in America today. For that reason and others, we argue that the results of this study have wider applicability than the administrative appeals setting.
} 
substantive outcomes of the cases. The data for this project will ultimately include three years of data and more than twenty different procedural steps, though this article focuses on only a subset of this data. This data set is larger in the number of cases collected than many recent empirical studies of representation, and has broader data collected about each case than previous studies.

Our first finding from this examination of representation in context is that less powerful parties gain more from representation than more powerful parties do. To test theories of balance power and representation, we ask whether one or both parties have lawyers, and then investigate the case outcomes across variation in balance of power and balance of representation. The data show that representation makes a difference, especially for claimants and especially for claimants when employers are not represented. Interestingly, claimants also benefit from representation when both parties are represented. In this context, the employer generally is the party with more power and corresponds with the "haves" in the civil justice system, while the claimant is the party with less power and corresponds with the "have nots." ${ }^{.5}$ As a result, we argue that while legal representation may offer advantages for anyone who can secure it, the benefit that flows from a representative's legal expertise is greatest for those who can least afford representation because the "haves" can acquire and use elements of legal expertise, ${ }^{6}$ even without actual representation. Thus when the "have nots" face the "haves" in a civil legal setting and without representation, they are at a disadvantage. If representation can shift

\footnotetext{
${ }^{5}$ See generally Marc Galanter, Why the "Haves" Come Out Ahead: Speculations on the Limits of Legal Change, 9 LAW \& SOC'Y REV. 95,160 (1974) (dividing parties in the civil legal system into "repeat players" and "one-shotters" and describing how well-resourced repeat players - the "haves" - gain advantage in litigation against one-shotters - the "have nots").

${ }^{6} I d$. at 98 . In this article, we will use the terms "legal expertise" and "professional expertise" interchangeably.
} 
the power dynamic in the civil legal setting, as we suggest it does, this raises the question of what lawyers are doing to make this shift.

Our second finding is that what representatives do to help parties is more complex and dependent on context than simply using the available law or procedure. Our data reveal that while all represented parties are more likely to appear at a hearing and use evidentiary steps than unrepresented parties, represented employers who use these steps have better case outcomes than represented employers who do not use the same procedures. In contrast, represented claimants who use certain evidentiary steps have comparatively worse case outcomes than represented claimants who do not use the same procedures. This finding is surprising because it challenges basic assumptions about how lawyers use law and procedure to help their clients. As discussed more fully below, this finding suggests a variety of explanations, including the interaction of use of procedures with substantive legal burdens, the nature of representation in this study's context, and the signaling function of lawyers. We argue that one important explanation is a lawyer's strategic expertise, an important and previously uninvestigated component of representation. If lawyers potentially contribute three types of expertise: substantive, relational, and strategic, the concept of strategic expertise captures how lawyers make choices by synthesizing the rules that govern their work and the informal relationships they navigate in the course of that work. All of these potential explanations will benefit from more research, underscoring our argument that it is not sufficient to ask whether a party is represented; we must also ask what the representative is doing for the party. In short, to understand representation we must examine it in context. 


\section{Previous Studies and Theories of Representation}

This study builds on existing scholarship in two areas: empirical studies of the effectiveness of representation and the development of theories of power, representation and expertise.

\section{A. Previous Empirical Studies}

Existing research overwhelmingly concludes that parties with representation fare better in legal disputes than those who are not represented. ${ }^{7}$ Other studies have attempted to answer the question of whether representation matters in general and in the same context - unemployment insurance appeals - as this study. ${ }^{8}$

Previous studies of unemployment appeals have engaged in questions of the effectiveness of representation by comparing success rates of claimants with representation to those of claimants without representation. ${ }^{9}$ All of these studies, save for the most recent one, reach the conclusion that representation improves a claimant's probability of winning, and these same studies also suggest that there are advantages to representation by non-lawyers, such as paralegals, law students, and lay representatives. ${ }^{10}$

\footnotetext{
${ }^{7}$ See Rebecca L. Sandefur, The Impact of Counsel: An Analysis of Empirical Evidence, 9 SEATTLE J. FOR SoC. Just. 51, 69 (2010) [hereinafter Sandefur, Impact of Counsel] As discussed below, we acknowledge that one study does not support this assumption and believe others have adequately discussed the limits of that study.

${ }^{8}$ See Sandefur, The Impact of Counsel, supra note 7, at 70-71. See also Jessica K. Steinberg, In Pursuit of Justice? Case Outcomes and the Delivery of Unbundled Legal Services, 18 GEO. J. ON POVERTY L. \& POL'Y 453 (2011) (examining the effectiveness of unbundled legal services).

${ }^{9}$ See Greiner \& Pattanyak supra note 1, at 2124; HERBERT M. KRITZER, LEGAL ADVOCACY: LAWYERS AND NONLAWYERS AT WORK 33-34 (1998) [hereinafter KRITZER, LEGAL ADVOCACY]; Maurice Emsellem \& Monica Halas, Representation of Claimants at Unemployment Compensation Proceedings: Identifying Models and Proposed Solutions, 29 U. Mich. J.L. REFORM 289, 291 (1996); Murray Rubin, The Appeals System, in 3 NAT'L COMM'N ON UNEMPLOYMENT COMP., UNEMPLOYMENT COMPENSATION: STUDIES AND RESEARCH 625 (1980).

${ }^{10}$ See KritZer, Legal AdvocaCy, supra note 9 at 76-77; Sandefur, Impact of Counsel, supra note 7 at 79.
} 
In a 1980 study, Rubin used national data to create a baseline observation of unemployment insurance appeal hearings. This study examined cases where the parties appeared at hearings and found representation rates for both parties of less than $10 \%$ and overall claimant win rates of $35.7 \%$, regardless of representation. ${ }^{11}$ Further, the Rubin study found that claimants won $30.8 \%$ of cases where employers appeared, but $45.4 \%$ of cases where employers appeared and the claimant was represented, and $49.3 \%$ of cases where both parties were represented. ${ }^{12}$

In a 1995 study, Emsellem and Halas analyzed data from unemployment insurance appeals in Ohio and found employers were represented four times (45\%) as often as claimants $(10 \%){ }^{13}$ The study found that unrepresented claimants won $34 \%$ of cases and represented claimants won $45 \%$ of cases. ${ }^{14}$

Kritzer's 1998 study examined unemployment insurance appeal data in Wisconsin, and for the first time parsed the data according to which party appealed and which party had the burden of proof, though the analysis was restricted to cases where both parties appeared for the hearing. ${ }^{15}$ Kritzer found that representation made no difference for employers (winning approximately $58 \%$ of cases whether represented or not), but that unrepresented claimants won $41.5 \%$ of cases and represented claimants won $50.4 \%$ of cases. ${ }^{16}$ Further, Kritzer found that when both sides brought a representative, claimants won $44.6 \%$ of cases, when representation was imbalanced in favor of the claimant,

\footnotetext{
${ }^{11}$ Rubin, supra note 9, at 628.

${ }^{12}$ Rubin, supra note 9, at 628.

${ }^{13}$ Emsellem \& Halas, supra note 9, at 292.

${ }^{14}$ Emsellem \& Halas, supra note 9, at 292. It is not clear whether this study included all appeals or only those where the parties appeared at the hearing.

${ }^{15}$ KRITZER, LEGAL ADVOCACY, supra note 9, at 33.

${ }^{16}$ KRITZER, LEGAL ADVOCACY, supra note 9, at 34.
} 
claimants won $53.4 \%$ of cases, and when representation was imbalanced in favor of the employer, claimants won $41.6 \%$ of cases. $^{17}$

In the most recent study, Greiner and Pattanayak used a randomized design to measure the effect of an offer of representation, and found that an offer of representation by clinical law students does not make a significant difference in a claimant's probability of winning. ${ }^{18}$ Of those claimants who received an offer of clinical law student representation, $76 \%$ won their cases, and of those who did not receive an offer, $72 \%$ won. ${ }^{19}$ The claimants who received an offer of representation waited longer for resolution of their case. ${ }^{20}$ In this more recent data from Massachusetts, in all cases, claimants won $47 \%$ of cases where the claimant appealed and $75 \%$ of cases where the employer appealed. $^{21}$ While others have raised critiques of this study, ${ }^{22}$ several characteristics of the Greiner and Pattanyak study are useful for understanding this article.

The core challenge of a non-randomized study, like the one presented in this article, is the effect of selection bias on the analysis of representation and case outcomes. For example, it may be that only the most sophisticated claimants or only employers with the strongest factual cases seek out representation, but there is no way of knowing the effect of these factors on the measured variables. The Greiner and Pattanyak study

\footnotetext{
${ }^{17}$ KRITZER, LEGAL AdVOCACY, supra note 9, at 34.

${ }^{18}$ See Greiner \& Pattanyak, supra note 1.

${ }^{19}$ See Greiner and Pattanyak, supra note 1, at 13.

${ }^{20} I d$.

${ }^{21}$ Greiner and Pattanayak, Randomized Evaluation, supra note 1, at n.54. It appears from the description of the sample for the study that while the appeals in this sample are legally de novo hearings, the process in these hearings is not necessarily a de novo review of the evidence. Id. at 2136. This difference in practice may lead to lower claimant win rates where claimants appeal.

${ }^{22}$ See, e.g., Fischman, supra note 2, at 166-67; Albiston \& Sandefur, supra note 1, at 106-13; Selbin et. al, supra note 1, at 48-51; Bob Sable, What Difference Representation - A Response, CONCURRING OPINIONS (Mar. 28, 2011), http://www.concurringopinions.com/archives/2011/03/what-differencerepresentation-a-response.html; David Udell, What Difference Presentation?, CONCURRING OPINIONS (Mar. 28, 2011), http:// www.concurringopinions.com/archives/2011/03/what-differencepresentation.html.
} 
overcame this challenge through randomization of the offer of representation, and relies heavily on its randomized design as its source of authority. We do not dispute the value of randomized studies, but we believe that relying solely on randomization of claimants' offer of representation and then observing win rates misses important opportunities to understand legal representation. ${ }^{23}$ For example, Greiner and Pattanayak's randomized design did not account for the ultimate representation status of claimants, whether they received an offer of clinical law student representation or not. Thus, their study ultimately provides limited insight into the relative experiences of claimants with different types of representation, or no representation at all. Similarly, the randomized design does not account for the representation status of the employer. As a result, the study's insight into the ultimate question of whether representation matters is also limited In addition, the Greiner and Pattanayak study does not investigate the level of participation by the parties or the representatives, including use of procedures and attendance at the hearing, and so does not engage in questions of what representatives actually do for parties. While our study does not rely on randomized design, it does use a substantial data set and valid statistical methods to observe and investigate correlations at a breadth and depth of analysis that has not previously been conducted. In particular, this article's analysis of the correlation between parties' use of procedural steps and case outcomes compares parties with the same representation status, thereby avoiding selection bias concerns. In sum, this study examines the experiences of parties with varying types of representation and participation in a way that a randomized study cannot. ${ }^{23}$ See Greiner \& Pattanyak, supra note 1, at 2198-220 (discussing limitations of randomized controlled
studies). 


\section{B. Existing Theories of Power and Expertise}

This study is also informed by existing scholarship regarding the role lawyers play in civil justice settings, including theories of the balance of power and of professional expertise. Scholars have developed theories of the role that lawyers play in civil justice settings and how representation interacts with a range of variables, including the area of law, the complexity of procedural rules, ${ }^{24}$ and the balance of power between the parties in a given dispute.

The relative power of the parties is not the only variable that may correlate with representation, but it is a critical one. While there is extensive theory about the role of party power in the legal system, there is limited empirical examination of this phenomenon. This article is intended to supplement our empirical understanding of power in the legal system. As a general matter, scholars have examined how socioeconomic status and social power have a relationship with a person or organization's interactions with law and the justice system. ${ }^{25}$ But if the operation of law

\footnotetext{
${ }^{24}$ See Rebecca L. Sandefur, Elements of Expertise: Lawyers' Impact on Civil Trial and Hearing Outcomes, (forthcoming, copy on file with authors) at 8 [hereinafter Sandefur, Elements of Expertise].

${ }^{25}$ Scholars from a range of fields, including law and sociology, have examined the relationship between the social power of individuals and groups and the operation of law and justice. The idea that legal doctrine, by itself, does not explain how cases are handled in the legal system, and that differences may be attributed in some measure to the social status of the parties, can be traced back to legal realism. In response to this idea, sociologists and legal scholars have attempted to explain the social factors that influence the operation of law. An early work in the field of legal sociology, Donald Black's Sociological Justice, published in 1989, explored how the social structure of cases and the power of parties predicts the way those cases are handled in the legal system. Black argued that law is "situational" and "relative" and explained how law varies with social status. He proposed that high status and low status parties experience the legal system differently as a baseline matter and noted that the treatment of a given case may be predicted by looking at the balance of power between parties. See generally Black, SociologiCal Justice (1989). More recently and in the context of access to justice literature, sociologist Rebecca Sandefur examined empirical approaches to studying the relationship between civil justice and various forms of social inequality. She notes:
}

Civil justice experiences can reflect inequality in the sense that inequalities that exist prior to contact with or in some other way outside law and legal institutions are 
and justice varies with social status, a full understanding of the impact of legal

representation requires understanding the status of each party to a dispute and their status

relative to each other. ${ }^{26}$

A corollary issue is the symbolic effect of a powerful party. Others have

theorized and investigated how a party's social status or power has a signaling function in the legal system. ${ }^{27}$ Scholars have theorized how individuals and businesses who have (or are perceived to have) higher status and better reputations are likely to be perceived more positively by judges and other court staff. ${ }^{28}$ Along the same lines, representatives may confer a signaling benefit on a party by virtue of their presence. The lawyer's presence reproduced when people and groups come into contact with justiciable events or legal
institutions. Such experiences can also create inequality, in the sense that differences
between people or groups become disparities through contact with justiciable events or
legal institutions. Finally, civil justice experiences can destroy or destabilize inequality,
as disparities are reduced through contact with justiciable events or legal institutions. Rebecca L. Sandefur, Access to Civil Justice and Race, Class, and Gender Inequality, 34 ANN. Rev. Soc. 339, 346 (2008) [hereinafter Sandefur, Race, Class, and Gender]. In legal scholarship, an expansive literature has assessed how social factors, including race, class, and gender, systematically influence law and justice. The literature explores issues such as the role of race in sentencing decisions, the effect of gender on jury selection, and the relationship between poverty, economic inequality, and constitutional law. Margaret Etienne, Pain and Race: A New Understanding of Race-Based Sentencing Disparities, 3 U. ST. THOMAS L.J. 496, 503 (2006) (explaining that "The fourth (and current) wave of research questions the existence and extent of race-based sentencing disparities in the post-guideline, or "determinate sentencing" era"). See generally Lucy Fowler, Gender and Jury Deliberations: The Contributions of Social Science, 12 WM. \& MARy J. Women \& L. 1 (2005); Stephen Loffredo, Poverty, Democracy and Constitutional Law, 141 U. PA. L. REV. 1277, 1278 (1993) (examining "the Supreme Court's use of the rationality standard in areas that affect poor people, and argues that the political powerlessness of the poor requires some form of enhanced judicial protection."); Julie A. Nice, Whither the Canaries: On the Exclusion of Poor People from Equal Constitutional Protection, 60 DRAKE L. REV. 1023 (2012). A goal of this article is to add to the literature by questioning how the combination of representation, a party's power, and the balance of power between the parties influences the legal process and the outcomes of cases in civil legal settings.

${ }^{26}$ See Black, Sociological Justice, supra note 25, at 10.

27 "In general, one sees evidence that lawyers, officials, and legal authorities, as well as perhaps legal procedures themselves, exhibit impaired comprehension of the disadvantaged and less powerful. However, in the case of class inequality... we have no studies comparing different groups' experiences handling similar problems or in similar hearing settings." Sandefur, Race, Class, and Gender, supra note 25, at 349 (citations omitted).

28 "Status expectations theory argues that the influence attempts of high-status individuals succeed, and those of lower-status people fail, due to socially shared cognitions and expectations that link social status to attributions about personal ability and worth." Karyl A. Kinsey \& Loretta J. Stalans, Which Haves Comes Out Ahead and Why: Cultural Capital and Legal Mobilization in Frontline Law Enforcement, 33 LAW \& SOC'Y REV. 993, 996 (1999). 
can signal to the court that the party is of some significance and that merits of the claim are worthy of consideration. ${ }^{29}$ This may be particularly true in courts with a large number of pro se litigants, where the presence of a lawyer is notable.

Finally, our examination of expertise builds upon existing scholarship regarding effectiveness in civil legal settings, and in particular on recent work by Rebecca Sandefur, who explores a lawyer's impact through a theory of professional expertise. Sandefur draws on sociological theories of professionalism to articulate two categories of a lawyer's professional expertise: substantive and relational expertise, or what might also be called "formal training" vs. "people knowledge."30

\section{Substantive Expertise}

Substantive expertise is the abstract and principled knowledge held by professionals and gained through formal training. ${ }^{31}$ In the legal context, this includes knowledge of the essential framework of professional theories, concepts, and rules as well as an understanding of how to operate within those rules. ${ }^{32}$ Thus, substantive expertise includes both law and procedure. ${ }^{33}$ Substantive legal knowledge consists of legal theories, common law rules, statutes, doctrine, case law, and other content-based

\footnotetext{
${ }^{29}$ See Sandefur, Elements of Expertise, supra note 24, at 42-43.

${ }^{30}$ See Sandefur, Elements of Expertise, supra note 24, at 7-8 (describing substantive and relational expertise); KRITZER, LEGAL ADVOCACY supra note 9, at 15-16, 194-95 (describing formal training and insider knowledge, or people knowledge, and a third category called process knowledge). Sandefur describes two aspects of legal expertise, substantive (Kritzer's "formal training") and relational (Kritzer's "insider" or "people" knowledge). Sandefur's substantive expertise category includes formal knowledge of the law, as well as procedural rules. In contrast, Kritzer places knowledge of procedural rules in a separate category called "process knowledge," which also includes lawyers' understanding of how a court or other legal institution operates and the processes involved in legal advocacy in that setting, such as the process of a given type of hearing in a given court.

${ }^{31}$ See Sandefur, Elements of Expertise, supra note 24, at 7-8. See also Stephen R. Barley, Technicians in the Workplace: Ethnographic Evidence for Bringing Work Into Organizational Studies, 41 ADMIN. SCI. QUARTERLY 404, 425-429 (1996).

${ }^{32}$ See Sandefur, Elements of Expertise, supra note 24, at 8; HERBERT M. KRITZER, THE JUSTICE BROKER: LAWYERS AND ORDINARY LITIGATION 7 (1990) [hereinafter THE JUSTICE BROKER].

${ }^{33}$ See Sandefur, Elements of Expertise, supra note 24, at 8.
} 
knowledge. ${ }^{34}$ In their work, lawyers draw on this knowledge to determine what law is relevant to a given client's case. Procedural knowledge is what lawyers use to move cases through the formalities of the civil justice system, such as the appropriate means of communicating with the court and opposing parties, the use of pleadings and motions, the mechanisms of introducing evidence, and the navigation of litigation timelines. ${ }^{35}$

Sandefur notes that an important use of substantive expertise is the translation of a client's real-world problems into legally cognizable terms. ${ }^{36}$ For example, transforming a client's experience of a car accident into an argument for liability and damages uses formal legal knowledge, while knowing where to file such a claim and how the applicable court processes work uses procedural knowledge. Through substantive expertise, a lawyer will identify which harms might have a legal remedy, such as physical injury and property damage, and which do not, such as psychological effects.

\section{Relational Expertise}

In contrast to the principled and rule-based nature of substantive expertise, relational expertise is "situated and contextual." 37 It involves understanding how to navigate the human relationships within which a professional's work takes place, including how to behave and how to communicate with others. ${ }^{38}$ This includes what can be called "people knowledge" and is the expertise that guides interactions with judges,

\footnotetext{
${ }^{34}$ See Sandefur, Elements of Expertise, supra note 24, at 8; KRITZER, THE JUSTICE BROKER, supra note 32 , at 7.

${ }^{35}$ See Sandefur, Elements of Expertise, supra note 24, at 8.

${ }^{36}$ See Sandefur, Elements of Expertise, supra note 24, at 8-9.

${ }^{37}$ Sandefur, Elements of Expertise, supra note 24, at 9

${ }^{38}$ See Sandefur, Elements of Expertise, supra note 24, at 9.
} 
court staff, clients, and other attorneys. ${ }^{39}$ It also includes the fact of having professional relationships with these actors.

A characteristic of relational expertise across professional contexts is that it is not typically part of the "explicit curriculum of professional training" despite the fact that it may be essential for a professional's success in her work. ${ }^{40}$ Many professionals learn relational skills outside of formal training and through experience in their day-to-day working lives. In addition, relational expertise operates on specific as well as general levels. There are ways of behaving and communicating that are fairly universal, but there are also ways of behaving and communicating that are context-dependent. For example, when speaking in court, a lawyer will address a judge with "Your Honor" because this is a universal practice in the profession. But that same lawyer, if she is new to the courtroom, will not have a sense of that particular judge's communication style and preferences until she has spent some time interacting with and observing the judge.

\section{Non-lawyers' Use of Professional Expertise}

Professional expertise is a powerful currency for a party to use in navigating the civil justice system. Consequently, representation by a lawyer confers advantages for those who can obtain it. ${ }^{41}$ But in the absence of representation, some parties to legal disputes can use the functional equivalent of professional expertise and thus the benefits that flow from it.

\footnotetext{
39 KRITZER, LEGAL ADVOCACY, supra note 9, at 196.

${ }^{40}$ See Sandefur, Elements of Expertise, supra note 24, at 9. This is traditionally the case in legal education, which emphasizes instruction in legal doctrine and formalized legal argument, particularly in the core courses of the first year of law school. Many law students graduate without any formal training to develop the knowledge and skills of relational expertise. However, the growth of clinical and other forms of experiential legal education has incorporated the development of relational expertise into the law school curriculum for some students.

${ }^{41}$ See Sandefur, Impact of Counsel, supra note 8, at 70-71. See notes 3-23 and accompanying text.
} 
Some parties may, as a baseline matter, possess the functional equivalent of professional expertise by virtue of factors unrelated to their involvement in the civil justice system, but most gain this equivalent expertise over time by virtue of their involvement as repeat players. ${ }^{42}$ Mark Galanter famously articulated how powerful parties, whether individuals or organizations, benefit from being repeat players, and how comparatively less powerful parties, the prototypical one-shot litigants, are disadvantaged. ${ }^{43}$ Galanter highlights the systemic power of parties who are repeat players in a given area of law as compared to the relative powerlessness of one-shot litigants. $^{44}$

Repeat players have frequent dealings with the legal system, can develop the functional equivalent of substantive expertise by anticipating the issues they will face in a given case, and thus can plan in advance for the litigation. These parties can also develop relational expertise by building relationships with court staff and judges, and thus develop both comfort and fluency in communicating with the people who work within a civil justice setting. People and organizations that repeatedly navigate legal disputes in a given area of law have the potential to develop knowledge and skill that mirror a lawyer's professional expertise. ${ }^{45}$ Due to a lack of formal training and routine practice, these litigants may not become fully expert, but they can develop a knowledge base and a set of

\footnotetext{
${ }^{42}$ See Russell Engler, Connecting Self-Representation to Civil Gideon: What Existing Data Reveal About When Counsel is Most Needed, 37 FORDHAM URB. L.J. 37, 79 (2010) (stating that "[r]epeat players are more likely to wield financial power, utilize a forum that serves their interests, benefit from the substantive law, and be familiar with the procedure"); Marc Galanter, supra note 5, at 96-107; Deborah Rhode, Access to Justice, 69 FORDHAM L. REV. 1785, 1806 (2001) ("Yet comparative research finds that nonlawyer specialists are at least as qualified as lawyers to provide assistance on routine matters where legal needs are greatest.").

${ }_{43}^{4}$ See Galanter, supra note 5, at 96-107.

${ }^{44}$ See Galanter, supra note 5, at 96-107.

${ }^{45}$ See Galanter, supra note 5, at 98, 114-15.
} 
skills and behaviors that give them significant strength in legal disputes, particularly those with which they are familiar.

Even parties that are not repeat players can use some elements of a lawyer's professional expertise, particularly relational expertise. For example, non-lawyers who are familiar with general norms of professional communication may have the ability to relate effectively to actors in the civil justice system. Other parties who are not repeat players may be able to obtain a basic level of substantive expertise through education by studying the law or reading a court's procedural rules. Finally, some individuals may seek the advice of an attorney but then choose to represent themselves, and thus they benefit from at least a measure of professional legal expertise. It is worth noting that those individuals most likely to seek out this substantive expertise in the first place are those who have some level of power and resources.

Of course, those parties that are the least likely to have some equivalent to professional expertise are those without the social, cultural, economic, or professional background to come to the legal process with this knowledge or to quickly adopt such knowledge during their interaction with a court. And, therefore, these parties are both the ones at the greatest disadvantage in the legal process and the ones who have the most to gain from representation and the expertise it provides.

\section{Data}

This article is part of a broader study based on the broadest and deepest collection of data about representation in recent years. The study is informed by our experience representing claimants in unemployment insurance appeal hearings before the D.C. Office of Administrative Hearings. Though we did not conduct formal qualitative 
observations of these hearings, two of the authors have supervised clinical law students in these cases over the course of four years and in more than a hundred cases combined. And this clinical practice has led to conversations with other representatives, judges, and court staff about various issues concerning representation in this context. The questions raised by the authors' experience in these cases were the impetus for this project, the relationships developed during these cases led to access to the data for this study, and the authors' observations contribute to the hypotheses in this article.

To identify a universe of cases for this article, we collected unemployment benefits appeals hearing data from the District of Columbia Office of Administrative Hearings for the year 2012. This data set encompasses 1,794 unique cases over the study period. $^{46}$ In order to ensure the greatest utility of the data, coded variables include:

- a party's representation (or lack thereof),

- the type of representation (lawyers, third parties, clinical students, lay representatives),

- the presence of representation at the hearing (as representatives do not necessarily attend the hearing),

- the appearance of parties at the hearing,

- the participation of parties in different procedural elements of the case, and

- the length of time for procedural steps and cases to be resolved.

As a key goal of the study is to understand the context of representation, we attempted to code every possible procedural element of each case, though only a subset of these procedures are addressed in this article. ${ }^{47}$ The coded variables include:

\footnotetext{
${ }^{46}$ The data discussed in this article are the result of a larger effort to collect data on all unemployment insurance appeals in the District of Columbia for 2011, 2012, and 2013. We anticipate that this data set will be available for the future research proposed at the conclusion of this article and will include approximately 7000 unique cases, approximately 5500 of which concern the circumstances of separation from employment.

${ }^{47}$ Some procedures, such as disclosure of witnesses, are excluded from this article because of small sample sizes in our one year data set. Other procedures, such as the use of motions, are not considered because we believe they are more complex and potentially implicate other areas of inquiry. Thus we plan to address them in future articles.
} 
- dates of the eligibility period,

- date and substance of the underlying agency (claims) determination,

- date of filing of the appeal,

- date and number of document disclosures,

- number of documents introduced,

- number of documents admitted,

- date and number of witnesses disclosed,

- date and outcome of requests for subpoena,

- date of any pretrial motions filed and their outcomes, ${ }^{48}$

- date of any hearings held,

- the appearance of parties at the hearing(s),

- the appearance of representatives at the hearing(s),

- any appearance and testimony by witnesses,

- telephone appearances,

- use of interpreter,

- verbal motion for judgment at a hearing,

- verbal voluntary dismissal at a hearing,

- date of any post-hearing motions and their outcomes,

- final procedural outcome, and

- final substantive outcome.

To collect the data, we engaged in a three-step process. First, we downloaded data from the court's case management system. Second, we supplemented and verified this data through review of each paper case file, conducted according to a comprehensive collection protocol. Third, we performed supplemental two-tier data checks of the paper case files and reviewed the collected data for both internal consistency and consistency with court procedures. The collected data was then coded according to a comprehensive coding plan to allow for the use of statistical software for analysis.

This article focuses on a subset of the data: all unemployment appeals where the circumstances of separation are at issue, regardless of which parties appeared at the hearing. This is not a sample of available cases, but rather every such case in the District

\footnotetext{
${ }^{48}$ Pretrial motions include those to withdraw the appeal, withdraw as representative, expedite the final order, continue the hearing, for a new hearing or to reopen a case, for relief from a final order, for reconsideration, for subpoena, for telephone hearing, to compel, noting intent not to appear, for judgment, for extension of time, to file under seal, to add a party, to quash, for an interpreter, to consolidate cases, to appear pro hac vice, to supplement the record, and to remand, as well as responses to these motions.
} 
of Columbia in 2012. This data set captures the breadth of circumstances where representation may have a correlation to outcomes and is a larger and broader sample than earlier studies. ${ }^{49}$ It does not, however, include the subset of unemployment appeals regarding underlying questions of eligibility and benefit calculation, as these appeals involve a state agency rather than the employer as the opposing party.

To understand the data, and thus our analysis of the context in which we investigate our hypotheses of balance of power and expertise, it is helpful to understand the details of the unemployment insurance appeals context in which our study operates.

\section{A. The Site of the Study}

The site of this study is the District of Columbia's central administrative court, the Office of Administrative Hearings (OAH). An independent agency created by the District government, $\mathrm{OAH}$ adjudicates cases involving a range of issues arising from the work of District agencies. ${ }^{50}$ The study focuses on a subset of OAH cases, unemployment insurance appeals regarding qualification. In these cases, an individual seeking unemployment insurance benefits - a claimant - faces his or her previous employer in a hearing before an Administrative Law Judge (ALJ) who will determine whether or not the claimant will receive unemployment insurance benefits.

\section{Unemployment Insurance Program}

Unemployment insurance is a social insurance program designed to provide shortterm cash payments to temporarily unemployed workers. The program, established in the 1930s in the wake of the Great Depression, was intended to limit the negative economic

\footnotetext{
${ }^{49}$ See supra, notes 7-23 and accompanying text.

${ }^{50}$ D.C. CODE $§ 2-1831.02$ (2013).
} 
effects of short-term unemployment. ${ }^{51}$ Unemployment insurance has been a particularly important part of the American social safety net in recent years in the context of record high unemployment rates triggered by the recession that begin in $2007 .{ }^{52}$ In the District, unemployment was as high as ten percent following the recession. ${ }^{53}$

Unemployment insurance is funded by a combination of federal and state payroll taxes assessed to employers. ${ }^{54}$ Federal law sets out the framework of the program including basic requirements that states must meet in order to receive federal funding. ${ }^{55}$ For example, federal law limits the amount of time any individual may receive unemployment insurance; however, during times of high unemployment, Congress may legislate extensions. ${ }^{56}$ Each state is responsible for administering its own unemployment insurance program and for paying benefits directly to unemployed individuals. ${ }^{57}$ Beyond the broad requirements set by federal law, states have flexibility in program design, including determining who may receive benefits, as well as the amount and duration of benefits. $^{58}$

\footnotetext{
${ }^{51}$ Comm. ON ECON. SEC. REPORT TO THE PRESIDENT (1935) (providing recommendations that were the basis of the Social Security Act, Pub. L. No. 271, 49 Stat. 620 (1935), which was codified in various sections of 42 U.S.C.).

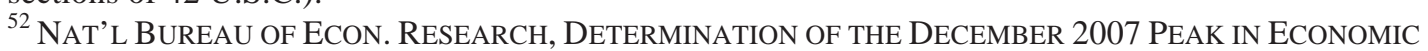
ACTIVITY at 1 (December 2008); "The national unemployment rate peaked at 10 percent in October of 2009.” Bureau of Labor Stats, U.S. Dep't of Labor, Spotlight on Statistics, The Recession of 2007-2009 (February 2012). "Unemployment benefits also reduce poverty significantly, especially when unemployment is high: they kept 2.5 million people (including 600,000 children) out of poverty in 2012. In 2009, when unemployment was higher and jobless benefits more generous, they kept 4.9 million people out of poverty (including 1.3 million children)." CTR. ON BUDGET AND POLICY PRIORITIES, CHART BOOK: THE WAR ON POVERTY AT 502 (January 7, 2014).

${ }^{53}$ BUREAU OF LABOR STATS, LOCAL AREA UNEMPLOYMENT STATISTICS, available at http://data.bls.gov/timeseries/LASST530000000000003 (last visited, March 13, 2014).

${ }^{54} 26$ U.S.C $\$ 3302$ (2014).

${ }_{55} 26$ U.S.C. $\$ 3301$ et seq. (2014).

${ }^{56}$ Unemployment Compensation Amendments of 1992, Pub. L. No. 102-318, 106 Stat. 290 (1992).

${ }^{57} 26$ U.S.C. $\$ 3301$ et seq. (2014).

${ }^{58} 42$ U.S.C. § 503 (2014).
} 


\section{Unemployment Insurance Law in the District}

In the District of Columbia, the question of whether an unemployed person may receive benefits is determined by a two-part test: eligibility and qualification. ${ }^{59}$

Eligibility includes the threshold requirement that a claimant has worked a sufficient amount of time and earned a minimum level of wages in the period leading up to the claim for unemployment insurance, known as the "base period."60 If the base period requirement is satisfied, then a claimant must certify - both in the initial claim for benefits and on an ongoing basis for each week that she receives benefits - that she is available for work and is actively seeking work. ${ }^{61}$ If the base period, availability, and job search requirements are met, then a claimant is eligible and the next inquiry is whether she is qualified for unemployment insurance. ${ }^{62}$

Qualification concerns the reason for the claimant's separation from employment.

As a general matter, the unemployment insurance program in most states is intended to pay only those who are unemployed "through no fault of their own." 63 Under District law, unemployed workers are presumed qualified for benefits, but may be disqualified from benefits for one of two reasons: because they were terminated for work-related misconduct or because they voluntarily quit without good cause. ${ }^{64}$

\footnotetext{
${ }^{59}$ The results presented in this paper include only cases where the legal issue is a claimant's qualification for benefits. We have made the analytical choice of separating the two data sets because the parties, the nature of representation, the hearing process, and the legal and factual issues involved in eligibility and qualification cases are substantively different and would make a combined analysis unworkable. In future work, we hope to explore the particular dynamics of eligibility cases, which also raise issues of power and legal expertise, albeit in different ways.

${ }^{60}$ D.C. CODE $§ 51-107$ (c) (2013).

${ }^{61}$ D.C. CODE $§ 51-109(2013)$.

${ }^{62}$ D.C. CODE $§ 51-109$ (2013).

${ }^{63}$ See Maurice Emsellem ET Al., Center on Budget and Policy Priorities, Failing

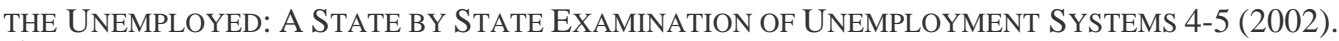

${ }^{64}$ D.C. CODE $§ 51-110$ (2013).
} 


\section{The Parties}

Our data set for this article includes unemployment appeals where the employer and the claimant are parties to the case. At first glance, it may seem odd that employers are involved in unemployment insurance claims at all - why would a company spend time and resources fighting a benefit administered by the government? Primarily, employers have a stake in these cases because the structure of the unemployment insurance program creates a financial incentive to contest unemployment claims. The amount an employer is required to contribute to the program through payroll taxes is based in part on the number of former employees who have received unemployment insurance. ${ }^{65}$ Sophisticated and large employers typically try to limit costs related to unemployment claims by minimizing the number of former employees who can make a successful claim for benefits. ${ }^{66}$

There is another less technical factor that may drive some employers to contest a worker's claim for benefits - emotion. The workplace can be complex and the grievances that plague some relationships between workers and supervisors can spill over into the context of an unemployment claim. Our observations of many unemployment cases suggest that some employers may contest a claim for benefits without consideration of any financial imperative, but instead due to a judgment that the former employee does not "deserve" benefits.

However, employers do not always oppose the grant of benefits for a former employee. ${ }^{67}$ An employer may have terminated the employee out of financial necessity

\footnotetext{
${ }^{65}$ D.C. CODE $\S 51-103$ (2013).

${ }^{66}$ See Jason deParle, Contesting Jobless Claims Becomes a Boom Industry, N.Y. TiMES, Apr. 3, 2010 , at Al.

${ }^{67}$ Employees sometimes believe that an "initial denial of benefits is the result of the employer's active opposition to the claimant's benefits when, often, a claims examiner will deny benefits based on a fact or
} 
or for some other reason unrelated to the worker's conduct; in these cases, the employer may affirmatively support the employee's grant of benefits. Still other employers may not be concerned about any financial consequences or may be otherwise uninterested in fighting the case.

In this study, we did not collect identifying or demographic data on either party, in part for confidentiality reasons and in part because the data was not consistently available in the case files. However, based on other research and our own observations, we can generally describe the characteristics of employers and claimants in unemployment appeals.

The employers who appear before OAH in unemployment cases range from small businesses to major corporations to federal agencies. ${ }^{68}$ Our anecdotal experience suggests that certain high-turnover industries that tend to pay lower wages may be overrepresented among employers; for example, private security, food service, janitorial, and health care companies were often the opposing parties in the cases we tried before OAH. In addition, due to a feature of the unemployment tax system, many non-profit employers have a strong incentive to participate. ${ }^{69}$

Claimants similarly include individuals from range of backgrounds and industries, from low-wage workers to lawyers who earned six-figure salaries. ${ }^{70}$ However, our

set of facts obtained without any agenda or even involvement on the employer's part." Colleen F. Shanahan, Cultivating Justice for the Working Poor: Clinical Representation of Unemployment Claimants, 18 GeO. J. ON POVERTY L. \& POL'y 401, 414 (2011).

${ }^{68}$ Based on authors' personal observations between 2011 and 2014.

${ }^{69}$ Under federal law non-profit employers may opt out of paying unemployment taxes and instead reimburse states directly for the cost of payments made to former employees. 26 U.S.C. § 3306(c)(8) (2014); 26 U.S.C.A. § 3309(a)(2) (2014).

${ }^{70}$ Based on authors' personal observations between 2011 and 2014. In the United States during 2013, the number of weekly claims was around $2,984,300,56.2 \%$ of which were by males while $43.2 \%$ were by females. The industries with the highest unemployment submissions were the Administration and Support/Waste Management/Remediation Services at 12.9\%, Construction at $11.9 \%$, and Manufacturing at 
observation and data from studies of unemployment claimants indicate that those who receive unemployment benefits are disproportionately poor or low-income and people of color. $^{71}$ In addition, for a variety of reasons too numerous to list here, low-wage jobs tend to expose workers to the possibility of being terminated, or present reasons for quitting a job, far more commonly than higher-wage work. ${ }^{72}$

\section{The Representatives}

Although most litigants are unrepresented, with claimants much more likely to be unrepresented than employers, there is a significant amount of representation in $\mathrm{OAH}$ cases. ${ }^{73}$ On the employer side, there are lay representatives and attorneys. On the claimant side, representatives are usually either attorneys or law students working in the context of a clinical education program, where an attorney supervises their work.

Employer lay representatives are typically employees or contractors working for third-party employer representation firms. OAH rules allow these lay representatives to appear on behalf of parties in unemployment appeals. ${ }^{74}$ Third-party firms are retained by employers, particularly by large companies, as a cost-reduction strategy and have varied levels of involvement in cases, depending on what the employer has retained them to

$9.8 \%$. The races with the highest claims rates were whites at $54.6 \%$, blacks at $17.3 \%$, and Hispanics at 16.2\%. U.S. DEP'T. OF LABOR, Characteristics of the Insured Unemployed (Mar. 29, 2004), available at http://workforcesecurity.doleta.gov/unemploy/chariu.asp (last visited March 24, 2014).

${ }^{71}$ See Austin Nichols \& Margaret Simms, Racial and Ethnic Differences in Receipt of Unemployment Insurance Benefits During the Great Recession, URBAN INSTITUTE BRIEF, 4 June 2012 (finding AfricanAmericans are less likely to receive unemployment benefits even after accounting for factors that affect benefit receipt for other workers); U.S. GOV'T ACCOUNTABILITY OFFICE, GAO-0701147, LOW-WAGE AND PART-TIME WORKERS CONTINUE TO EXPERIENCE LOW RATES OF RECEIPT 3 (2007) (finding low-wage workers were half as likely to receive UI benefits despite being two and a half times more likely to be out of work, even where job tenure for both groups was similar).

${ }^{72}$ Christine Vestal, An UnEmployment Insurance BAlancing ACt, StATEline, The Daily News SERVICE OF THE PEW CHARITABLE TRUSTS, http://www.pewstates.org/projects/stateline/headlines/anunemployment-insurance-balancing-act-85899374819 (last accessed March 13, 2014) (finding low-wage and part time workers are less likely to quality for unemployment benefits as other workers).

${ }^{73}$ See infra, Figure 4.

${ }^{74}$ D.C. MuN. REGS. tit. 1, § 2982.1 (2013). 
Shanahan, Carpenter, \& Mark, Representation in Context

DRAFT - August 11, 2014

do. ${ }^{75}$ A firm may manage an employer's entire unemployment insurance cost-reduction

program or only part of it. Services include handling correspondence with DOES and

$\mathrm{OAH}$, collecting and submitting evidence, all the way up to full representation at a

hearing. ${ }^{76}$ The actual representatives who appear may be paralegals, may have years of

experience in unemployment appeals, or may have little experience at all.

When an attorney appears on behalf of employers at $\mathrm{OAH}$, the attorney may be a

private lawyer, in-house counsel for the company (this is particularly common where the employer is a District or Federal government agency), or part of a program run by the

Chamber of Commerce, which provides attorney representation to employers who qualify for services. $^{77}$

On the claimant side, the most common attorney representatives work for the District AFL-CIO's Claimant Advocacy Program, which provides free legal representation to claimants. ${ }^{78}$ The Legal Aid Society also assists unemployment

${ }^{75}$ See deParle, supra note 66.

${ }^{76}$ See e.g., Help Control Unemployment Claims Cost, Maximize Human Capital, and Mitigate Risk, ADP (March 13, 2014), https://www.adp.com/solutions/large-business/services/tax-andcompliance/unemployment-claims.aspx; Unemployment Cost Management, EQUIFAX (March 13, 2014), http://www.talx.com/Solutions/Compliance/UnemploymentTax/.

The [District of Columbia] UI statute authorizes funding for two organizations to provide free legal services to parties in UI appeals, one for employees and one for employers. The Claimant Advocacy Program (CAP), sponsored by the Metropolitan Washington Council, AFL-CIO, assists employees who have been "denied unemployment compensation in D.C. or whose benefit awards have been appealed by the employer." The employer counterpart to the CAP program is the Employer Assistance Program (EAP), which provides free legal assistance to employers in UI appeals. The Washington Area Chamber of Commerce sponsors the EAP program.

Enrique S. Pumar \& Faith Mullen, The Plural of Anecdote is Not Data: Teaching Law Students Basic Methodology to Improve Access to Justice in Unemployment Insurance Appeals, 16 UDC L. REV. 17, 23 (2012).

${ }^{78} I d$. at 24. 
claimants on a limited basis, and a number of local law schools provide student attorney representatives in unemployment appeals. ${ }^{79}$

\section{Hearing Process and Procedure}

In the District, the Department of Employment Services (DOES) administers the unemployment insurance program. An individual seeking unemployment benefits begins the process by filing a claim with DOES, which makes the initial determination. After receiving notice of DOES's determination, any party to the case, the claimant or the employer, may appeal the determination to $\mathrm{OAH}$ within fifteen days and receive a hearing before an ALJ. Following the hearing, the ALJ will issue a final order that explains the factual and legal basis of their decision. An ALJ's decision may be appealed to the District of Columbia Court of Appeals, a court that has been active in interpreting the unemployment statute and regulations in recent years with an emphasis on construing District law to favor the grant of benefits to claimants. ${ }^{80}$

OAH hears all unemployment insurance appeals in the District, along with a range of other cases such as public benefits, rent control, business and professional licenses, and building, health, and fire code violations. ${ }^{81}$ The individuals who serve as ALJs are lawyers appointed to the court by a special commission for full time seven year

\footnotetext{
${ }^{79} I d$. While we acknowledge it is an imperfect distinction, for the purposes of this article, we consider only licensed lawyers as attorneys, and all other representatives, including law students, as non-attorney or lay representatives. A future article, using the larger three year data set, will investigate these distinctions more closely.

${ }^{80}$ The District of Columbia Court of Appeals has emphasized the "humanitarian purpose of the [unemployment compensation] statute," see e.g., Johnson v. So Others Might Eat, Inc., 53 A.3d 323,326 (D.C. 2012), and has repeatedly stated that the unemployment insurance program is a "remedial humanitarian [program] of vast import," and that the statute and regulations implementing it must be "liberally and broadly construed," see e.g., Bowman-Cook v. Washington Metropolitan Area Transit Authority, 16 A.3d 130, 134 (D.C. 2011).

${ }^{81}$ District of Columbia Office of Administrative Hearings, www.oah.dc.gov/page/about-oah (last visited February 4, 2014).
} 
terms. ${ }^{82}$ The ALJs conduct hearings in a recently renovated facility where courtrooms include audio and video technology, a bench, a witness stand, tables and chairs for litigants, and space for an audience. ${ }^{83}$ As a result of the renovations, OAH looks and feels similar to a traditional civil court setting; in fact, all ALJs began wearing robes following the renovations. ${ }^{84}$

In unemployment insurance appeals, the parties to a qualification case are the claimant, who is seeking benefits, and the employer. Either party may be the appellant in the case. The hearings are de novo, which means the ALJ takes evidence in the case and makes factual determinations and conclusions of law without regard to DOES's initial determination. ${ }^{85}$ An unemployment insurance hearing begins with the baseline legal presumption that a claimant is entitled to benefits, and it is up to the employer or DOES to prove otherwise. ${ }^{86}$ Thus, a lawyer can exercise substantive expertise in making sure the client attends the hearing. Because the hearing is de novo and the employer has the burden of proof, if a claimant attends and the employer does not, the claimant automatically wins.

The hearing process in unemployment cases generally follows a basic pattern.

The ALJ makes a threshold determination regarding whether the court has jurisdiction to hear the case, a determination that may require testimony by the appellant. ${ }^{87}$ Jurisdiction is based on the timeline of the appeal; if a party files an appeal outside of the fifteen-day

\footnotetext{
${ }^{82}$ D.C. Mun. REGS. subt. 6-B $§ 3700$ (2013).

${ }^{83}$ Authors' personal observations between 2011 and 2014. See also description of District of Columbia Office of Administrative Hearings renovation, http://dgs.dc.gov/page/office-administrative-hearings-buildout (last visited March 13, 2014).

${ }^{84}$ Authors' personal observations and conversations with Administrative Law Judges at the District of Columbia Office of Administrative Hearings.

${ }^{85}$ See Rodriguez v. Filene's Basement Inc., 905 A.2d 177, 179-80 (D.C. 2006).

${ }^{86}$ See D.C. CODE $§ 51-110$ (2013).

${ }^{87}$ Based on authors' personal observations between 2011 and 2014.
} 
time window, the court may not have jurisdiction to hear the case and will dismiss the appeal. $^{88}$

Next, the ALJ will turn to the issue of separation from employment. That is, why is the unemployed person no longer working for this employer? At this point, the only information the ALJ has is the DOES determination, which is not, as a matter of law, substantive evidence in the case. ${ }^{89}$ However, as a practical matter, the document gives the ALJ some idea of the issues at play in the case. ${ }^{90}$ Although practices vary by judge, ALJs typically begin this portion of the hearing by explaining the underlying law, including the burdens of proof, and by informing each party of their role in the hearing. ${ }^{91}$

Because the claimant is presumed qualified for benefits, hearings begin with the employer's case-in-chief, during which the ALJ will hear from the employer and any employer witnesses, and will consider any documents or other evidence presented by the employer. Next, the ALJ will take evidence from the claimant, who may also have witnesses or documents. The ALJ may ask questions of either party and may also allow the employer to present a rebuttal case.

Although this basic pattern is followed by most ALJs in most hearings, individual judges have different styles and preferences. ${ }^{92}$ As OAH has been part of a recent effort in

${ }^{88}$ See D.C. CODE $\S 51-111(\mathrm{e})(2013)$.

${ }^{89}$ See D.C. CODE § 51-110 (2013).

${ }^{90}$ Authors' personal observations between 2011 and 2014. Judges sometimes state on the record that they have read the claims determination and that it has given them some sense of the potential legal and factual issues in the case. Most of the time, a judge will also note that the hearing is de novo and explain the functional meaning of that term to the parties.

${ }^{91} I d$.

${ }^{92}$ See Shannon Portillo, The Adversarial Process of Administrative Claims: The Process of Unemployment Insurance Hearings (unpublished manuscript) (on file with authors) (concluding, based on a sociological study of 45 unemployment insurance hearings at $\mathrm{OAH}$, that "the hearing runs like traditional courtroom litigation" but that when claimants represent themselves, "[ALJs] engage directly with the claimant, gathering as much information as possible." In contrast, when counsel is present "ALJs behave in traditionally passive ways, allowing each party to present their case."). 
the District of Columbia to improve access to justice for pro se parties, ALJs have

focused on providing more consistent and clearer descriptions of concepts like burdens of proof and use of testimony in hearings with unrepresented parties. ${ }^{93}$ For example, some judges, when faced with an unrepresented employer, may ask the employer to give a narrative about why the claimant was separated from employment. Other judges may ask a series of very direct questions and refuse to hear a longer narrative. Still other judges use a balance of these two approaches.

\section{a. Burdens of Proof}

Burdens of proof are an important part of the legal and procedural landscape of an unemployment hearing, as in any litigation. As a matter of procedure, the burden of proof determines which party must present evidence first. As a matter of law, the party with the burden must provide the evidence necessary to prevail under the law. Under District law, which party carries the burden varies between misconduct cases, where a claimant was terminated, and "quit" cases, where a claimant resigned.

In a misconduct case, the employer bears the burden of proving, by a preponderance of the evidence, that the claimant was terminated for a reason that amounts to misconduct under District law. In such hearings, the ALJ will typically instruct the employer to present evidence first, followed by the claimant. If the claimant resigned from the position, the employer bears to the burden of proving the claimant quit voluntarily. ${ }^{94}$ The burden then shifts to the claimant to prove that the resignation was for good cause as defined by District law.

\footnotetext{
${ }^{93}$ See infra, n. 105.

${ }^{94}$ D.C. MuN. REGS. tit. 7, § 311 (2013).
} 
The burden of proof has a significant impact on the strategic choices that parties, including legal representatives, make in presenting unemployment cases. Because the hearings are de novo, a threshold issue in any appeal hearing is whether it is a misconduct or quit case. An obvious question is, if the ALJ cannot consider the claims determination as evidence, how does the ALJ determine who has the burden? In practice, ALJs often begin the hearing by asking one or both of the parties to describe what is at issue in the case. Some judges will only ask this question of the employer, while others will ask it of the claimant, or of both parties.

As a matter of strategy, depending on the factual issues at play, it may be in a claimant's interest to allow the employer to speak first, but in some cases, it may be in the claimant's interest to attempt to define the issues from the beginning. For example, the facts of a claimant's separation from employment may blur the line between termination and resignation. To understand this concept, consider this example.

Wilma worked as a security guard, earning minimum wage, for Security Guards Inc. Wilma has a high school education and has never been involved in a legal proceeding. SGI is a company with approximately 700 employees. Wilma is fired from her job after she gets a new supervisor who does not like her. The supervisor and Wilma had several heated exchanges over the length of Wilma's breaks, exchanges that were very upsetting for Wilma. In addition, in a period of three weeks Wilma was late to her shift three times: by 4 minutes, 6 minutes, and 7 minutes. Wilma's supervisor wrote her up each time and then fired her after the third incident for violating the company's attendance policy.

Wilma files for and is denied unemployment benefits by her state labor agency based on a finding that she was fired for misconduct. Wilma files an appeal and attends her hearing by herself. SGI sends Elaine, the director of Human Resources to the hearing. Elaine handles 5-10 unemployment benefits hearings for SGI each year.

Now imagine if Wilma knew she was about to be fired, perhaps because she heard statements to that effect from other employees. Rather than face the potential 
embarrassment of being fired, Wilma chose to resign instead. Unfortunately for Wilma, it may be very difficult to win an unemployment insurance appeal under District law on resignation.

In basic terms, the law makes it quite easy for an employer to prove that a claimant quit voluntarily, and very difficult for a claimant to then prove that she quit with good cause. The legal standard for quit cases sets a high bar for claimants to meet. However, if the ALJ believes the claimant was fired, and the employer has to prove misconduct, it may be a much easier case for a claimant to win, given the nature of the legal standard for misconduct, which places the burden of proof on the employer. Thus, if Wilma has a sophisticated representative, she may assess the facts and law and determine that Wilma's chances of winning will be greatly improved if the ALJ applies a misconduct analysis. Despite the fact that the employer technically has the burden of proof, and even if the ALJ turns to the employer first, the representative may make the strategic choice to make a statement to the ALJ noting that Wilma was functionally terminated, with the hope that this small remark will plant the right seed in the ALJ's mind.

An alternate scenario, where Wilma is unrepresented, might result in Wilma saying at the beginning of the hearing that she quit because she wasn't being treated well by the employer, they were always getting on her case about her breaks, and she had enough of it. Wilma may be operating out of a desire to protect her own personal prideshe may not want to admit that she was about to be fired for something she did on the job. Unfortunately for Wilma, satisfying her personal instincts may defeat her legal case. 
The burden of proof also presents critical choices about offering evidence. In a misconduct case where the employer has the burden, it is often unwise for a claimant to offer much evidence at all, other than evidence that undercuts the employer's case-inchief. A claimant may unwittingly make a statement, introduce a document, or call a witness who provides facts that actually harm the claimant's case, and help the employer's argument for misconduct. Just like a defendant in a criminal trial, the wisest strategy for a claimant is often to say as little as possible, and when speaking, to only address the issues presented by the other side.

A nuanced understanding of the role of burdens in unemployment appeals can make the difference between a claimant winning or losing. In our experience, it is the natural instinct of a claimant who was fired to want to tell the story of the events that led to the termination, including all the negative information about the employer that he can muster. However, the employer is not on trial and the claimant has no burden of proof in a misconduct case. Any evidence the claimant offers runs the risk of actually adding additional facts that support a finding of misconduct. In this context, representatives can frame issues and present evidence in the light most favorable to their client. ${ }^{95} \mathrm{~A}$ representative might also decline to put a claimant on the stand to testify, based on an assessment that the employer's evidence is too weak and the claimant's potential testimony too damaging to risk opening the client up to cross-examination or questioning by the ALJ. Similarly, a representative might make a motion at the close of the employer's case, pursuant to a little-used OAH rule, asking that the claimant be granted benefits because the employer has not carried the burden of proof.

${ }^{95}$ KRITZER, LEGAL AdVOCACY, supra note 9, at 39. 
An understanding of burdens of proof can also affect preparation for a hearing. For example, a claimant's lawyer may present her client's testimony in a limited way so that the employer has to present evidence to uphold its burden, rather than relying on the claimant's testimony. Similarly, a representative may prepare the client for the hearing by explaining the particular court and judge, so that the client knows what to expect, feels more confident, and thus, is a better witness. ${ }^{96}$

\section{b. Evidence Disclosures}

Another critical aspect of hearing procedure, one that relates to burdens of proof, is an $\mathrm{OAH}$ procedural rule that governs the disclosure of evidence prior to a hearing. The rule requires a party to send to the court and the opposing party, at least three days prior to the hearing, any documents and a list of any witnesses that the party plans to offer at the hearing. ${ }^{97}$ This "three-day rule" is designed to ensure that parties, and the court, have notice of evidence that will be presented at a hearing.

Parties may choose to disclose, and ultimately introduce, a variety of documentary evidence. For employers, this may include documents such as employee policies, documents reflecting discipline of the employee such as prior warnings, communications between the employee and supervisors about conduct or the circumstances of separation from employment, or documentary evidence of conduct such as video or written reports. Claimants may have documentary evidence including communications with supervisors reflecting permission or acquiescence to conduct, documents reflecting contrary or supplementary policies, communications regarding the

\footnotetext{
${ }^{96} I d$. at 38.

${ }^{97}$ D.C. Mun. Regs. tit. $1 \S 2985$ (2010).
} 
circumstances of separation from employment, or evidence of mitigating circumstances such as health problems, family demands, or failure to be paid.

The three-day rule presents a choice for claimants, employers, and their representatives; if there are documents or witnesses you may want to use at the hearing, do you disclose them? For employers, the choice is fairly simple. If you want to be sure the evidence gets in, you should probably disclose it. For claimants, the picture is more nuanced. The rule has an exception for evidence that will be used for impeachment or rebuttal, which leaves an opening for claimants to introduce evidence without disclosing it. ${ }^{98}$ Thus, a representative may decide not to disclose documents in advance in a misconduct case, relying on an attempt to use the documents as rebuttal or impeachment at the hearing. In contrast, in a resignation case, a claimant may be more likely to disclose documents. A claimant or representative without appropriate expertise might disclose documents to the claimant's disadvantage based on an assumption that disclosure is required or on a misunderstanding of the burdens of proof in the case.

Similarly, a representative can contribute her expertise by gathering evidence and preparing evidentiary arguments based on her understanding of what evidence will be useful and whether documents or testimony are more powerful. ${ }^{99}$ This is particularly important for employers, who are required to bring witnesses with personal knowledge and documentation of the incidents to meet their burden of proof. Experienced or represented employers may begin gathering evidence from the day an employee starts work (for example, having the employee acknowledge receipt of company policies) and will be able to easily access these records for an unemployment hearing. In contrast,

\footnotetext{
${ }^{98} I d$.

${ }^{99}$ KRITZER, LEGAL ADVOCACY, supra note 9, at 39-41.
} 
unrepresented claimants are unlikely to appreciate or operationalize the need for documents or other evidence for the strategic power of disclosing (or not disclosing) evidence. This documentation is particularly important for claimants to try to exclude or at least discredit the weight of hearsay evidence. In general, understanding, preparing, and asking good questions on direct and cross examinations of witnesses is also an element of expertise in presenting evidence. So in Wilma's case, a lawyer may make the choice to introduce the competing employer policies, discussed above, or to object to Elaine's testimony on hearsay grounds because Elaine's office location means she did not witness any of Wilma's conduct.

Although unemployment hearings are not procedurally complex compared to protracted civil litigation, the cases do present significant layers of legal and procedural choices for any party or representative. The ability of a litigant to navigate these legal and procedural steps can make the difference between winning and losing. Similarly, the range of representatives' expertise may lead to a range of procedural behaviors.

\section{B. Representation and Outcomes Across Studies}

There is interesting variation among the previous studies of unemployment insurance appeals and this project. In the present study, in all cases with any level of participation by the parties, the claimant won in $67 \%$ of the cases. The overall claimant win rate in this study is higher than in previous studies. ${ }^{100}$ In addition to differences in samples, this variation may be explained by the fact that unemployment regulations in many states, including the District of Columbia, have evolved in the decades since the Kritzer, Emsellem and Halas, and Rubin studies. Specifically, states have enacted

${ }^{100}$ See supra, n. 8-24 and accompanying text. 
statutory or regulatory exceptions in favor of claimants, including exceptions granting benefits for claimants who are victims of domestic violence, ${ }^{101}$ relocate with spouses, ${ }^{102}$ or are caretakers for sick family members. ${ }^{103}$ In addition, the tribunal for this study, the District of Columbia Office of Administrative Hearings, is unusual in that it is a highly professionalized administrative court that hears a variety of administrative appeals. ${ }^{104}$ As such, it has been the subject of a variety of efforts aimed at protecting the rights of pro se litigants, including a revision of the D.C. Code of Judicial Conduct, effective January 1, 2012. Based on the 2007 American Bar Association model code of judicial conduct, these changes emphasized the affirmative duty of judges to facilitate the use of the courts by pro se litigants. ${ }^{105}$ Thus, one would expect the nature of judicial conduct at the site of the present study would result in higher win rates for claimants who benefit from this assistance. Each of these factors is likely to contribute to the greater win rates for

\footnotetext{
${ }^{101}$ In addition to the District of Columbia, there are 35 states that have extended unemployment benefits to cover victims of domestic violence. THE WoMEN's LEGAL DEFENSE AND EDUCATION Fund, STATE LAW

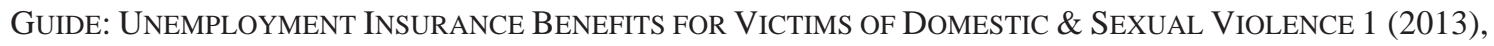
available at http://www.legalmomentum.org/sites/default/files/reports/State\%20Guide\%20UI\%20Final\%20June\%2020 13.pdf.

${ }^{102}$ An exemption for claimants who voluntarily leave his or her employment for the purpose of relocating with his or her spouse exists in some states, including D.C., but it is unavailable in others. See, e.g. Wash. Rev. Code Ann. § 50.20.050(2)(b)(iii) (West 2009), Va. Code Ann. § 60.2-618 (West 2013); see also 27 A.L.R. 6th 123 (2007).

${ }^{103}$ Most states, including D.C., provide exceptions for caregivers of family members with an illness, others provide very limited exceptions in some cases and others do not provide an exemption for this circumstance. See, e.g., Conn. Gen. Stat. Ann. § 31-236 (West 2009), Fla. Stat. § 16. 443.101(1)(a)(2013).

${ }^{104}$ This is in contrast to unemployment insurance appeal hearings in other jurisdictions that have been the subject of other studies. See Greiner and Pattanayak, Randomized Evaluation, supra note 1, at 55-57; KRITZER, LEGAL ADVOCACY supra note 9, at 27.

${ }^{105}$ See Zoe Tillman, D.C. Courts System Adopts New Code of Judicial Conduct, THE BLOG OF LEGAL TIMES (Jan. 23, 2012), http://legaltimes.typepad.com/blt/2012/01/dc-courts-system-adopts-new-code-ofjudicial-conduct.html (explaining additional changes made to the D.C. Code of Judicial Conduct for pro se litigants beyond what is provided by the ABA Model Rules, including that judges may change the order in which they collect evidence, explain or avoid legalese, and suggest additional resources that may help a pro se litigant.). See generally D.C. Code Jud. Conduct Rule 2.6 (2012). In addition to the District of Columbia, 24 states have adopted provisions similar to the 2007 ABA Model Code of Judicial Conduct to help a litigant's ability to be fairly heard. Margaret J. Vergeront and Jeff Brown, Access to Justice Commission Update, THE THIRD BRANCH (Dec. 11, 2013) http://wicourts.gov/news/thirdbranch/docs/fall13.pdf.
} 
claimants as compared to earlier studies. However, as noted above, this study is less concerned with overall win rates and more concerned with the relative advantages provided by representation, as measured by case outcomes.

\section{Hypotheses and Methodology}

\section{A. Hypotheses}

This article analyzes the data using two sets of questions: how the balance of power between the parties and representation interact and what role a representative's expertise plays in the process.

\section{Representation and Balance of Power}

The first area of analysis proposes that the central question of whether representation matters necessarily requires looking at both the balance of representation and the balance of power of the parties. The first hypothesis is based on the prediction that representation provides the represented party with an advantage $e^{106}$ and that this advantage is greater when the parties have imbalanced representation, where one party has representation and the other does not. Layered underneath this balance of representation is the balance of power between the parties themselves, which we hypothesize offsets the representation advantage. As a general matter, in this hypothesis and the ones that follow, we are using the employer as a proxy for the more powerful party in civil legal processes generally and the claimant as a proxy for the less powerful party in the civil legal process. ${ }^{107}$ This first hypothesis also includes the view that when

\footnotetext{
${ }^{106}$ See note 7 and accompanying text.

${ }^{107}$ We acknowledge that employers and claimants, like all parties, are a variety of individuals and institutions. However, we believe that the general characteristics of claimants and employers in
} 
the parties are both represented, the claimant gains a greater advantage from

representation than the employer because the claimant has less power to begin with.

Thus, we hypothesize that represented parties have higher win rates than unrepresented

parties, and that when representation is imbalanced in favor of one party, the party has

an even higher win rate.

\section{a. Appearance of Representative}

As it is possible for a party to have a representative of record who does not actually appear at the hearing, ${ }^{108}$ this hypothesis also examines the relationship of the appearance of a representative to case outcomes. This additional layer of representation a representative who actually appears at the most important moment of representation - is something that has not yet been studied and is a critical element of a conversation about representation. ${ }^{109}$ In unemployment appeals in particular, the hearing is the focal point of activity because it is a de novo evaluation of the case and because court procedures provide for limited activity outside the hearing. There is limited motion practice, and particularly very limited substantive briefing. If a party or her representative does not

unemployment insurance appeals make the use of these parties as proxies for "haves" and "have nots" a fair one. See, infra, note 124.

${ }^{108}$ See supra, n. 76. There are a variety of situations where a representative of record may not appear at a hearing. It may be that a party has a retained representative who is the contact for service of process. Thus, there is a representative of record but that representative might not actually be asked to be involved in the handling of a case. It may also be that a party retains a representative to help a human resources employee prepare for the hearing, but does not want to spend the money to pay the representative to attend the hearing. It may also be that a party indicates to the court that she has a representative, but in fact does not or ceases retaining that representative before the hearing. It is the authors' anecdotal impression that these situations are more likely to occur for employers, where the lay representative industry involves large companies that provide claims management as well as actual representation. These distinctions in representative type are a topic for future research.

${ }^{109}$ This analysis also avoids concerns about randomizing representation and selection bias, as the entire sample in this section of the analysis is parties with representation. For a discussion of selection bias challenges in research on the effects of representation, see Greiner \& Pattanyak, supra note 1, at 2193-95. 
appear at a hearing, and especially if it is the party with the burden of proof, that party is unlikely to win the case.

In this regard, we hypothesize that a representative who shows up at a hearing increases the advantages of having a representative of record. A party with a representative who appears should correlate with better case outcomes, and an imbalance in representatives at the hearing should correlate with proportionally better case outcomes for the party with the representative who is present. Thus our first hypothesis includes the corollary that represented parties whose representative appears at the hearing have higher win rates than those whose representative does not appear at the hearing.

\section{Representation and Strategic Expertise}

Questions of the operation of representation and the interaction of power and expertise can be better understood by looking in more detail at the choices parties make in the litigation process. As described in more detail below, the procedures from our data examined for this article are (1) whether the party appears at the hearing, (2) whether the party presents testimony, (3) whether the party discloses documents before the hearing as required by court procedures, (4) whether the party introduces documents at the hearing, and (5) whether the party has documents admitted at the hearing. ${ }^{110}$ We focus on these procedures as they are the most commonly used steps for a party to present evidence in a case, as compared to procedures that are less commonly used and result in changes in the procedural path of a case. Our analysis of these five procedures allows us to gain an

\footnotetext{
${ }^{110}$ We use the terms "appearance" and "evidentiary steps" to capture the five variables measured in this article, and the term "procedures" to describe the more general concept. There is admittedly some variation in the nature of the procedural steps considered in this hypothesis. One variable - disclosure of documents - occurs before the hearing, while the other variables occur at the hearing. Some variables - disclosure and introduction of documents and bringing witnesses to a hearing - measure the party's choice to engage while the final variable - admission of a document - measure the success of the use of that procedure.
} 
initial understanding of representation in context based on a large number of cases and using procedures that have a substantive relationship to the outcome of a case.

Our second hypothesis is that parties appear and use evidentiary steps more when represented, and that this use of procedures is correlated with better case outcomes. The first part of this hypothesis is based on the understanding that a representative's substantive expertise will result in greater knowledge, and thus use, of procedures. The second part of this hypothesis is based on the analysis that a representative's expertise will lead to engaging in steps that are more likely to be successful for the party. We hypothesize that this use of procedures encompasses more than simply knowledge of the procedures because a representative may lend additional contextual or strategic expertise to the use of procedures. This more strategic use of procedures may include an employer, who bears the burden, making greater use of steps that allow the party to present evidence and similarly may include a claimant, who does not bear the burden, using such steps less often. In either case, we hypothesize that the strategic use of procedures that comes with representation leads to better case outcomes. Thus our second hypothesis is that represented parties, including those whose representative appears at the hearing will appear at the hearing themselves and use evidentiary steps more than parties whose representative does not appear. Further, we hypothesize that those parties with representatives who use these evidentiary steps have higher win rates than those represented parties who do not use the same steps.

\section{B. Methodology}

In this article, we use a combination of cross tabulations and difference in proportions tests to demonstrate patterns of relationships between the variables of interest 
present in the data. Cross-tabulation allows us to demonstrate basic patterns of correlation in the data, and difference in proportions tests allow us to further investigate the relationships of interest through statistical testing of the comparison of groups.

Cross-tabulation is a descriptive statistical tool that summarizes data into contingency tables by grouping the frequency of interrelation between variables. ${ }^{111}$ Difference in proportions tests allow us to determine if certain outcomes of interest (e.g., winning or losing an appeal) can be attributed to a statistically significant difference between groups based on the presence or absence of an additional characteristic of interest (e.g., having representation or not). ${ }^{112}$ In this initial examination of the data, we seek to identify meaningful patterns in the data that may be further tested by more complex empirical methodology in future work.

We recognize the criticisms lodged against observational studies about the impact of representation. ${ }^{113}$ Though our access to data and the ethical challenges of randomizing representation mean this study is not based on a randomized design, it is based on all unemployment cases, rather than a sample, in the relevant time period. ${ }^{114}$ We note that we do not call what we do "causal" and instead use statistical methods to compare groups and demonstrate the correlative relationships between representation and case and procedural outcomes. While we recognize the limitations of our analysis, we believe our observations are still meaningful. Even though it is not operating from a random sample, our approach of using a complete set of cases to look at differences between groups

${ }^{111}$ Philip Pollock III, The EsSENTIALS OF POLitiCal ANALYsis 59-61 (4 $4^{\text {th }}$ Ed. 2012).

${ }^{112}$ Alan Acock, A GENTLE InTRODUCTION TO STATA 142 ( $2^{\text {nd }}$ Ed. 2014).

${ }^{113}$ See notes 3-23 and accompanying text.

${ }^{114}$ An example of the logistical and ethical challenges of randomizing the contextual questions we raise is: even if one could randomize ethically the fact of representation for a party, it is hard to imagine how to randomize ethically whether a particular party presented testimony or introduced a document, in order to measure the corresponding case outcomes. 
provides important insights into the questions of representation, balance of power, and strategic expertise that frame future work to test the theories we develop in this article.

\section{Dependent Variables: Case and Procedural Outcomes}

Our first dependent variable, and the classic dependent variable in studies of representation, is case outcomes - whether a party wins or loses the case. At the outset, it is important to note that the overall rate at which parties win is less meaningful in a study such as this one that looks at comparative case outcomes based on independent variables such as representation. Because our theories concern the relative advantages of representation, the more important analysis is case outcomes for the same party in light of different independent variables.

While our hypotheses necessarily require looking at case outcomes, they also require engaging in another level of dependent variables: procedural outcomes. For this paper, we identified five dependent variables that are different procedural steps in the unemployment appeals process, and their corresponding outcomes. The steps examined in this data as dependent variables are (1) whether the party appears at the hearing, (2) whether the party presents testimony ${ }^{115}$, (3) whether the party discloses documents before the hearing as provided by court procedures, (4) whether the party introduces documents at the hearing, and (5) whether the party has documents admitted at the hearing. For each procedural step, we examine two distinct questions: (1) whether having a representative results in greater use of the procedure and (2) for those parties with representatives (or those without), whether using each procedural step correlates with improved case

\footnotetext{
115 This variable is defined broadly - whether there is any testimony for a party's case - to encompass both parties who themselves testify (i.e. did Elaine or Wilma testify) and witnesses whose testimony is elicited by parties (i.e. did Elaine bring another company employee to testify). We use this broad definition because our interest is in the choice by the party or representative to present testimony.
} 
outcomes. ${ }^{116}$ Examining these dependent variables provides additional nuance to the interaction of representation, strategic expertise, and power.

In the entire sample, regardless of representation, claimants and employers used procedures at the rates shown in the table below.

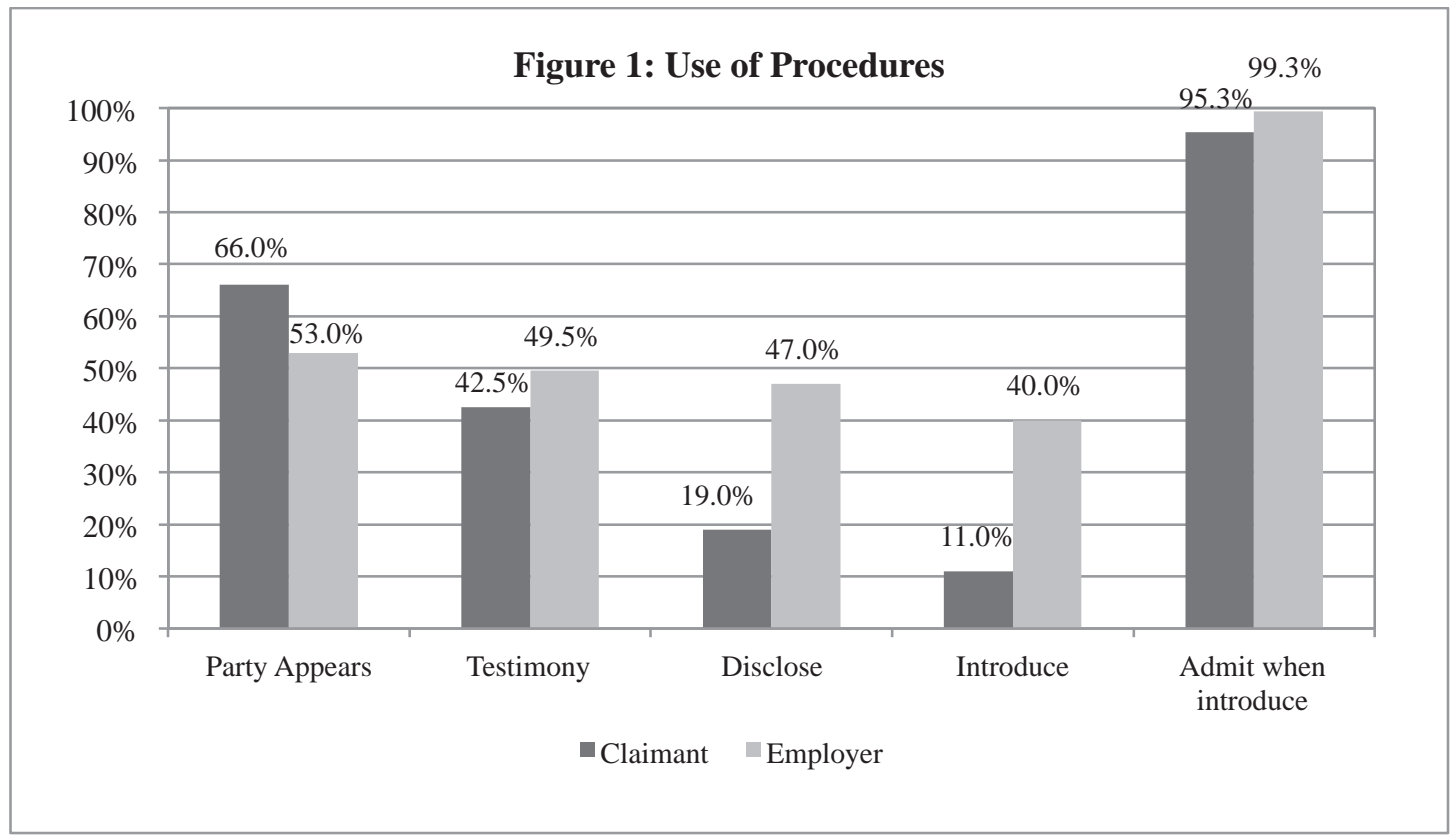

And for the entire sample, regardless of representation, use of each procedural step results in the case outcomes in the table below.

${ }^{116}$ For all of these dependent variables, our analysis includes all of the cases in our sample, regardless of whether or which party appeared at the hearing and thus whether a full hearing was held. We include all of these cases because we cannot know why one party or its representative appears at a hearing. For example, this may be due to an imperfect appeal, ignorance, inadvertence, or a party or representative's strategic choice. 
Shanahan, Carpenter, \& Mark, Representation in Context

DRAFT - August 11, 2014

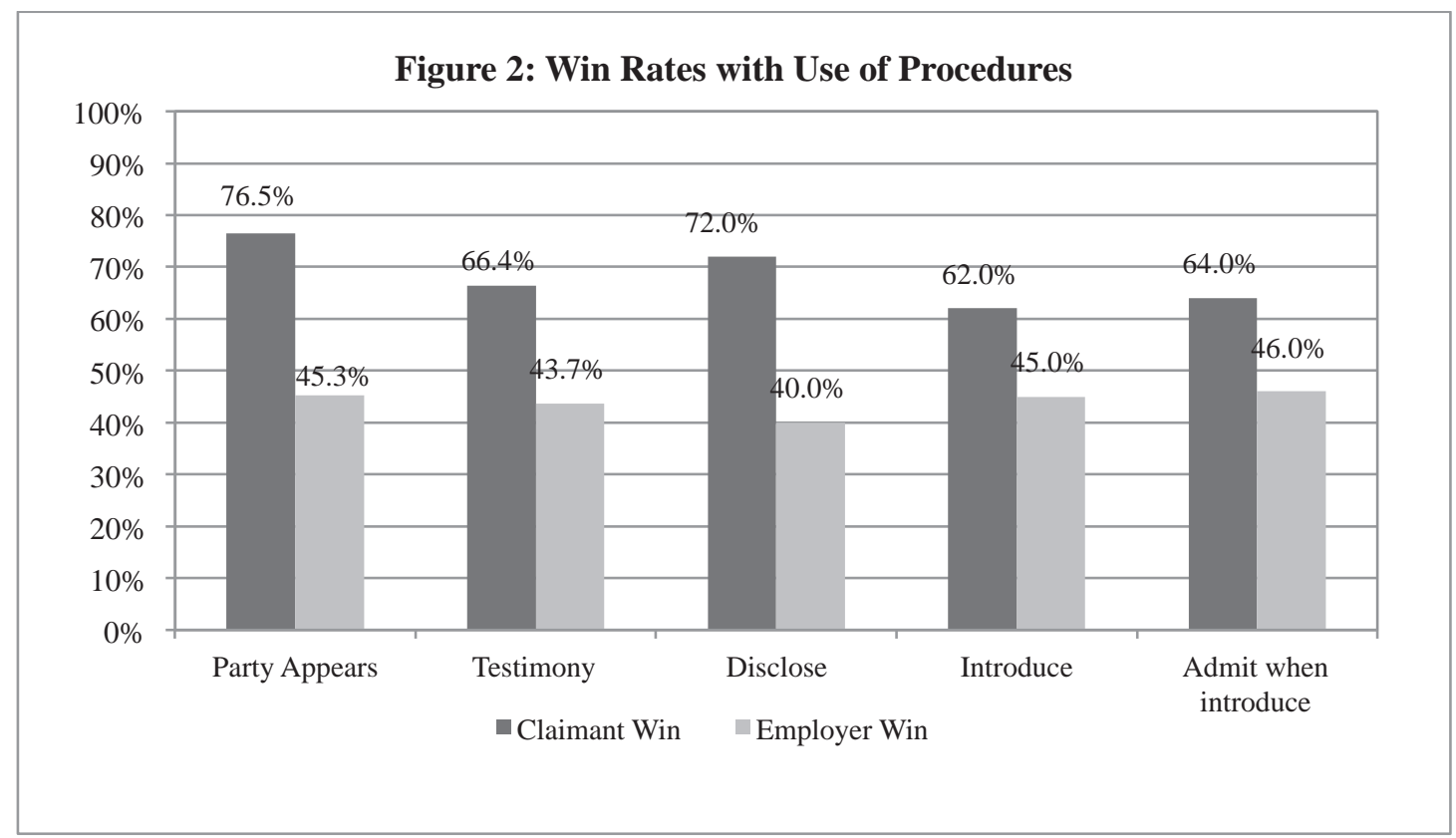

\section{Independent Variables: Representation and Balance of Representation}

Our hypothesis that representation provides the represented party with an advantage, and that this advantage is greater when the parties have imbalanced representation, begins with the independent variable of the fact of representation. A closely related independent variable is the balance of representation between the parties does one party have a representative or both? 
Figure 3: Representation Balance

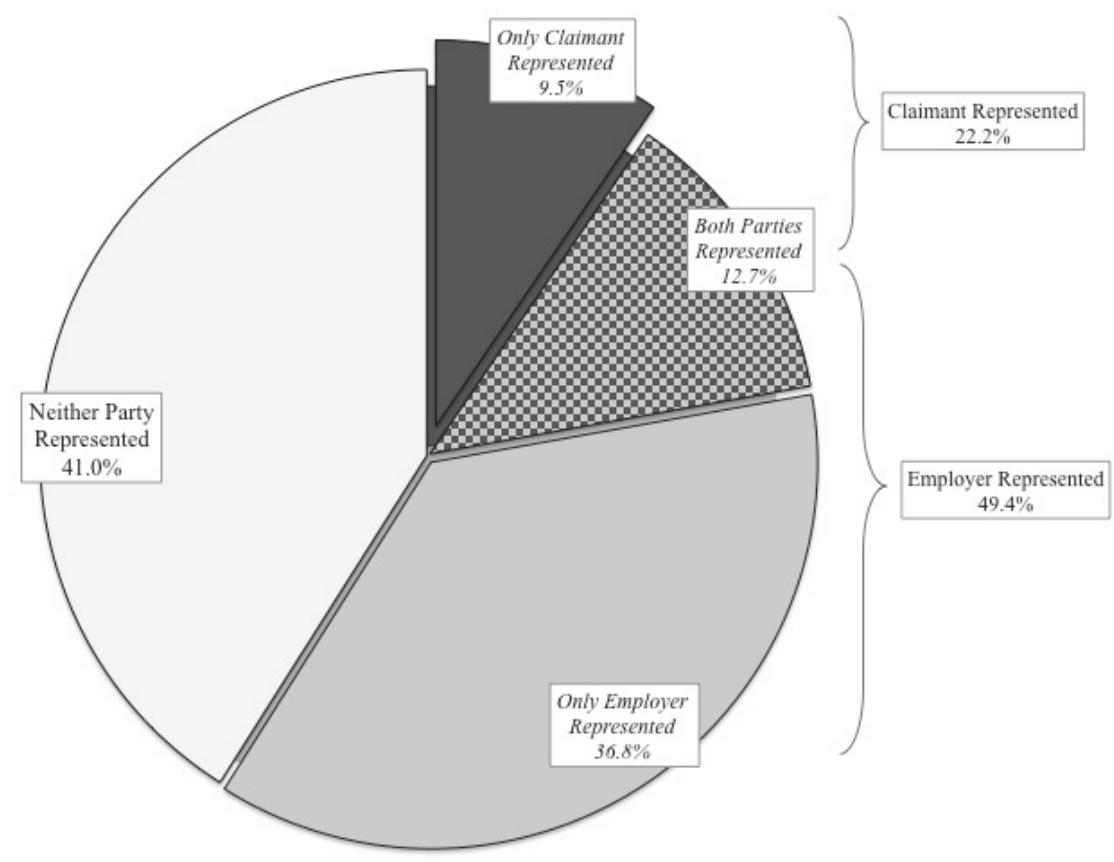

In our data, employers had some kind of representation more than twice as often as claimants, with claimants having representation in $22.2 \%$ and employers in $49.4 \%$ of the cases. As for the balance of representation, the parties both have representation in $12.7 \%$ of cases and neither has representation in $41.0 \%$ of cases. It is rare for a claimant to have representation when an employer does not, only occurring in $9.5 \%$ of the cases. In contrast, an employer has representation when a claimant does not in $36.8 \%$ of the cases.

\section{Independent Variable: Representative Appearance at Hearing}

As it is possible for a party to have a representative of record who does not actually appear at the hearing, another independent variable is whether a representative 
actually appears at a hearing. ${ }^{117}$ In our data, $51 \%$ of employers with representatives and $65 \%$ of claimants with representatives have that representative appear at the hearing.

\section{Findings}

This section summarizes our findings in light of our hypotheses. In the following section, we discuss the implications of these findings and areas for future research.

\section{A. Representation and Balance of Power}

Despite variation in parties' overall win rates and rates of representation, represented claimants have a significantly higher win rate than claimants who are not represented. ${ }^{118}$ In contrast, represented employers do not have a significantly different win rate as compared to unrepresented employers. Further, either a claimant or employer with unbalanced representation in their favor has higher win rates for that party than for those parties without the representation advantage. A claimant also has a higher win rate when both parties are represented, as compared to claimants when both parties are unrepresented. Finally, the appearance of a representative has a similar relationship to win rates for both employers and claimants when compared to parties when the representative does not appear.

\footnotetext{
${ }^{117}$ See supra, n. 108 for a discussion of situations where a representative of record may not appear at a hearing.

${ }^{118}$ As this article uses difference in proportion tests to demonstrate patterns of relationships between the examined variables, we report our findings as comparisons, e.g. "represented claimants have a higher win rate than unrepresented claimants." For ease of expression, we do not reiterate each time we describe a finding that this describes two distinct groups: the group of claimants in the data who were represented and the group of claimants in the data who were not represented, rather than the experience of a single claimant exposed to the presence and absence of the variable of representation.

In addition, we use the word "significant" to report statistically significant findings, as reflected in Appendix A. All of the differences described in this article are statistically significant unless explicitly described otherwise.
} 
In examining the relationship between representation, power, and case outcomes, it is helpful to have an understanding of the nature of case experiences for each party. Representation is more common for employers, with employers represented in $49.4 \%$ of cases and claimants represented in $22.2 \%$ of cases. As shown in Figure 4, claimants' win rates are significantly different when represented, while unrepresented employers do not see a significant difference in win rates compared to represented employers.

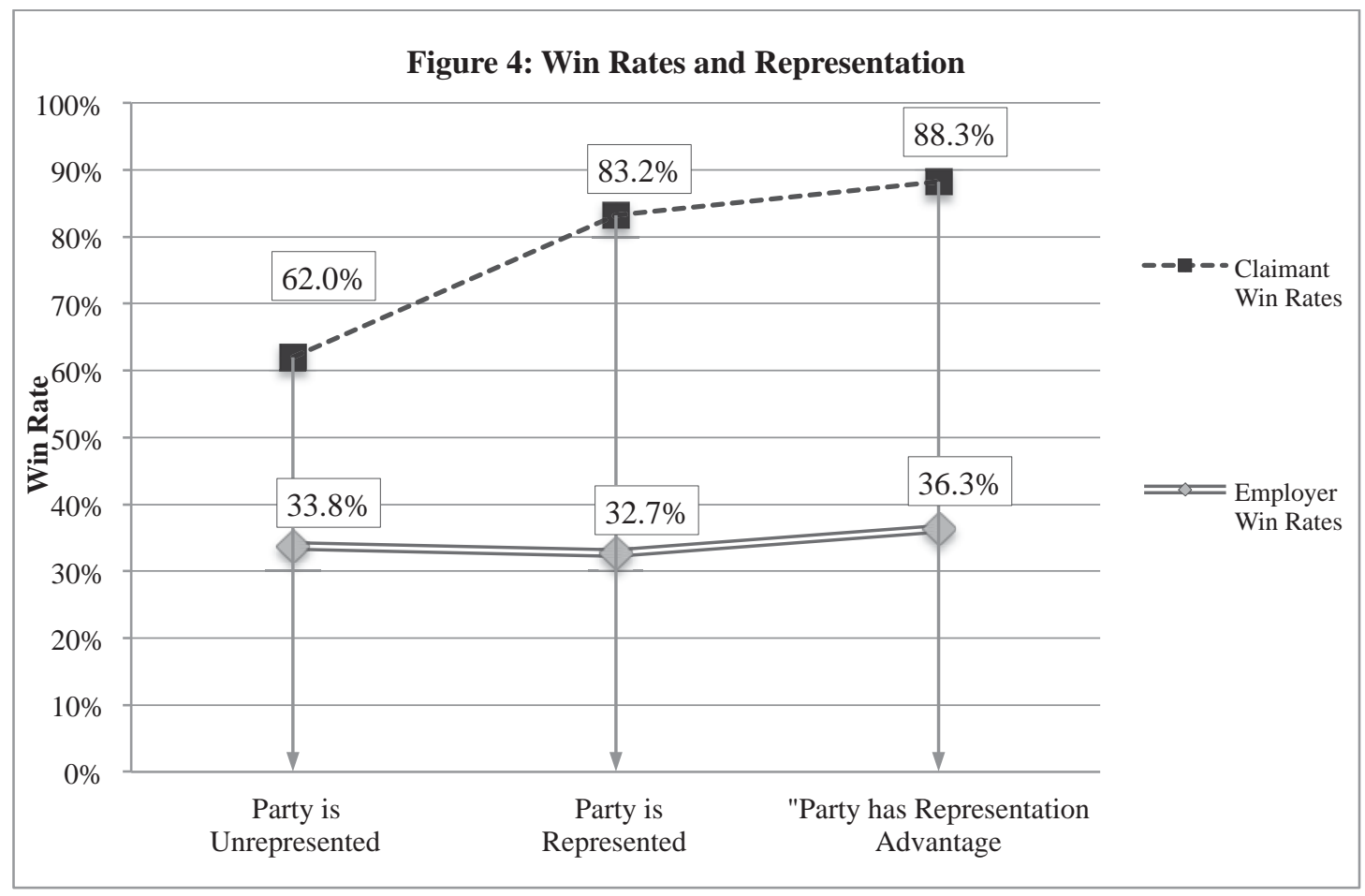

An additional layer of analysis is whether a party with representation imbalanced in its favor sees higher win rates than a party in a case with balanced representation. Figure 4 also shows how both a claimant and an employer with a representation advantage see a significantly higher win rate, compared to a claimant and an employer without that advantage. In addition, as shown in Figure 5, the data demonstrate that claimants have higher win rates when both parties have representation, as opposed to when both parties do not have representation. Employers see the reverse relationship. 


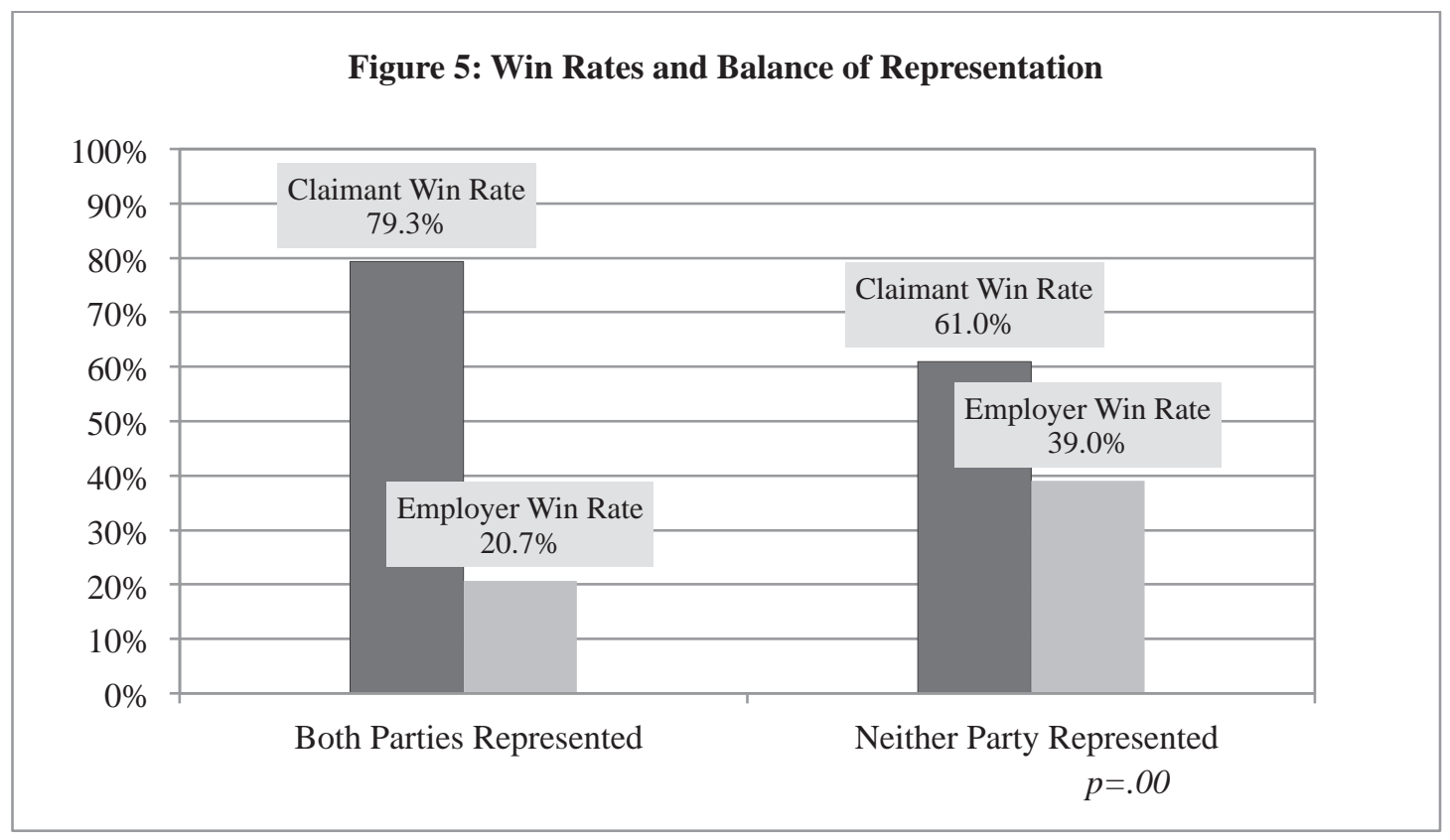

Employers and claimants have different correlations between a representative who appears at a hearing and win rates. When an employer has representation of record, the employer wins a significantly greater number of cases, winning $23.9 \%$ of the time when the representative does not show up as compared to $46 \%$ when the representative does appear. When a claimant is represented and their representative appears, there is no significant difference in the proportion of cases the claimant wins as compared to represented claimants whose representative does not appear. This result is not particularly surprising, as there is a high correlation between a claimant having representation and the representative showing up at the hearing. In very few instances does a claimant retain representation and the representative does not appear. Thus, it is difficult to determine the additional benefit of representative appearance, given both the high win rate in the represented group, as well as the high rate of appearance by that representation. 
Imbalance in the appearance of a representative has a similar relationship to win rates as overall imbalance in representation. Claimants for whom a representative appears for a party win a significantly greater amount of the time when no representative appears for the other party, as compared to when representation appearance is balanced. When representation is unbalanced in favor of the employer, the employer wins a significantly greater amount of the time, compared to when representative appearance is balanced.

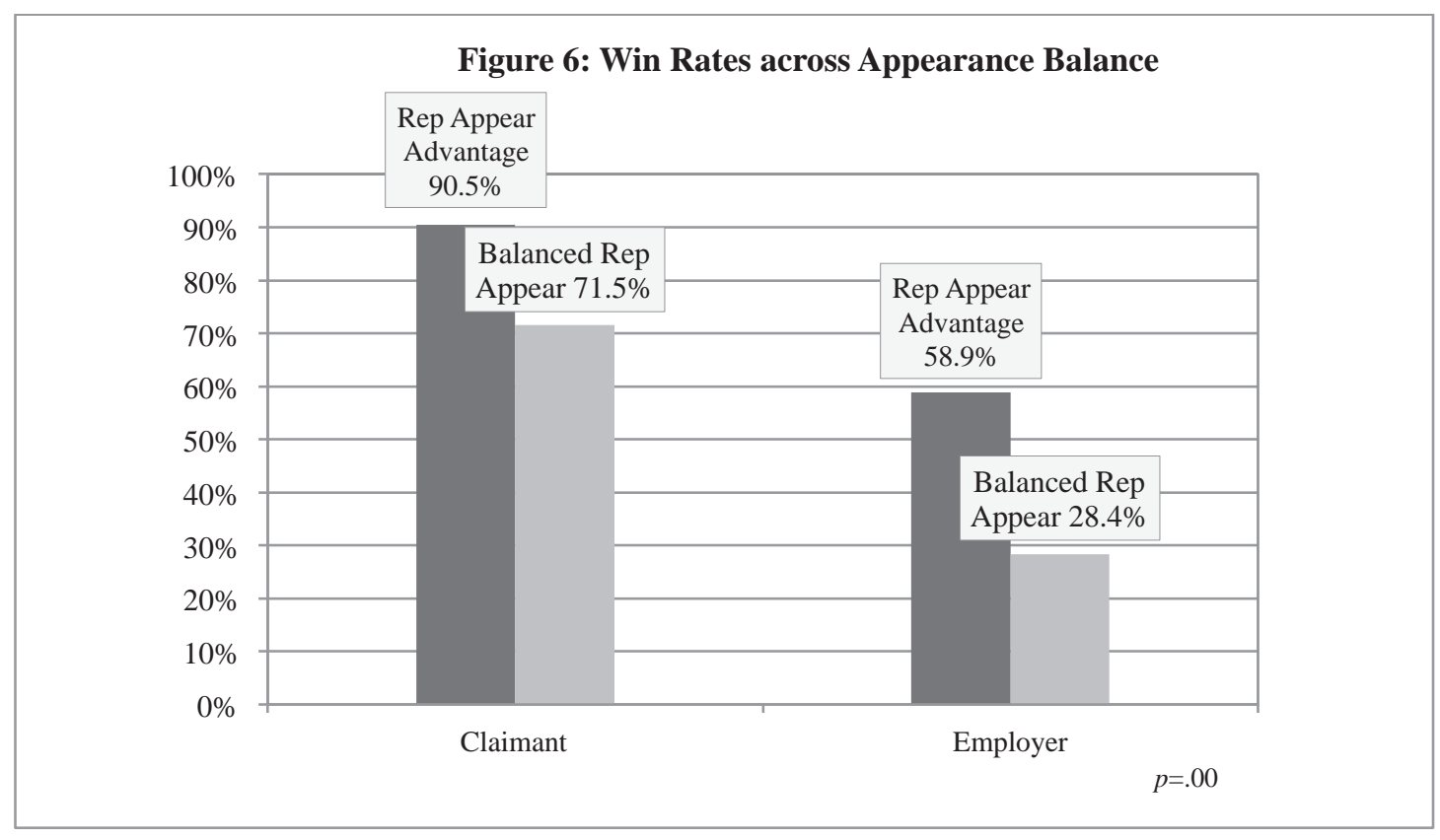

\section{B. Representation and Strategic Expertise}

The second area of inquiry takes a broader look at the interplay of power and expertise. The data reveal that for claimants and employers who are represented, and for those whose representatives appear at a hearing, the party's appearance and the use of evidentiary steps is higher than for unrepresented parties, and for those parties whose representatives do not appear at the hearing. But, the relationship between this use of evidentiary steps and case outcomes reveals more complicated results, with represented 
employers' use of these steps correlated with higher win rates, but represented claimants' use of these steps correlated with lower win rates.

\section{Party Appearance at Hearing}

Both parties have higher rates of appearance when they have a representative, and both see advantages in outcomes from their appearances.

As Figure 7 shows, when a claimant has a representative, the claimant appears at the hearing at a significantly higher rate, compared to when the claimant does not have a representative. If a claimant's representative appears at the hearing, claimants also attend the hearing at a higher rate, compared to the group in which the claimant's representative does not appear.

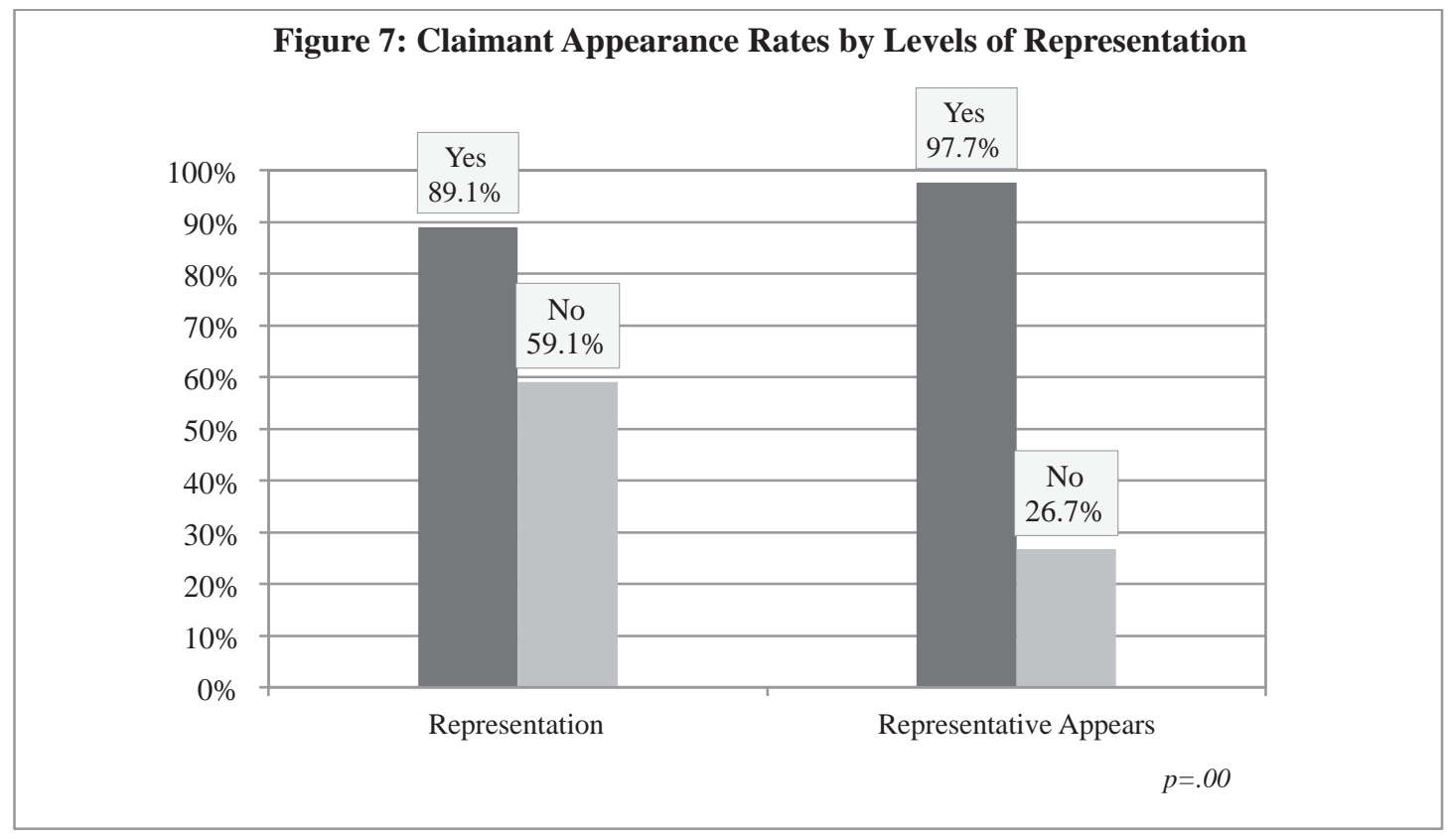

An employer appears at the hearing at a significantly higher rate when represented, and an employer whose representative appears at the hearing has a significantly higher rate of appearance at the hearing, compared to employers whose representative does not appear, as shown in Figure 8. 


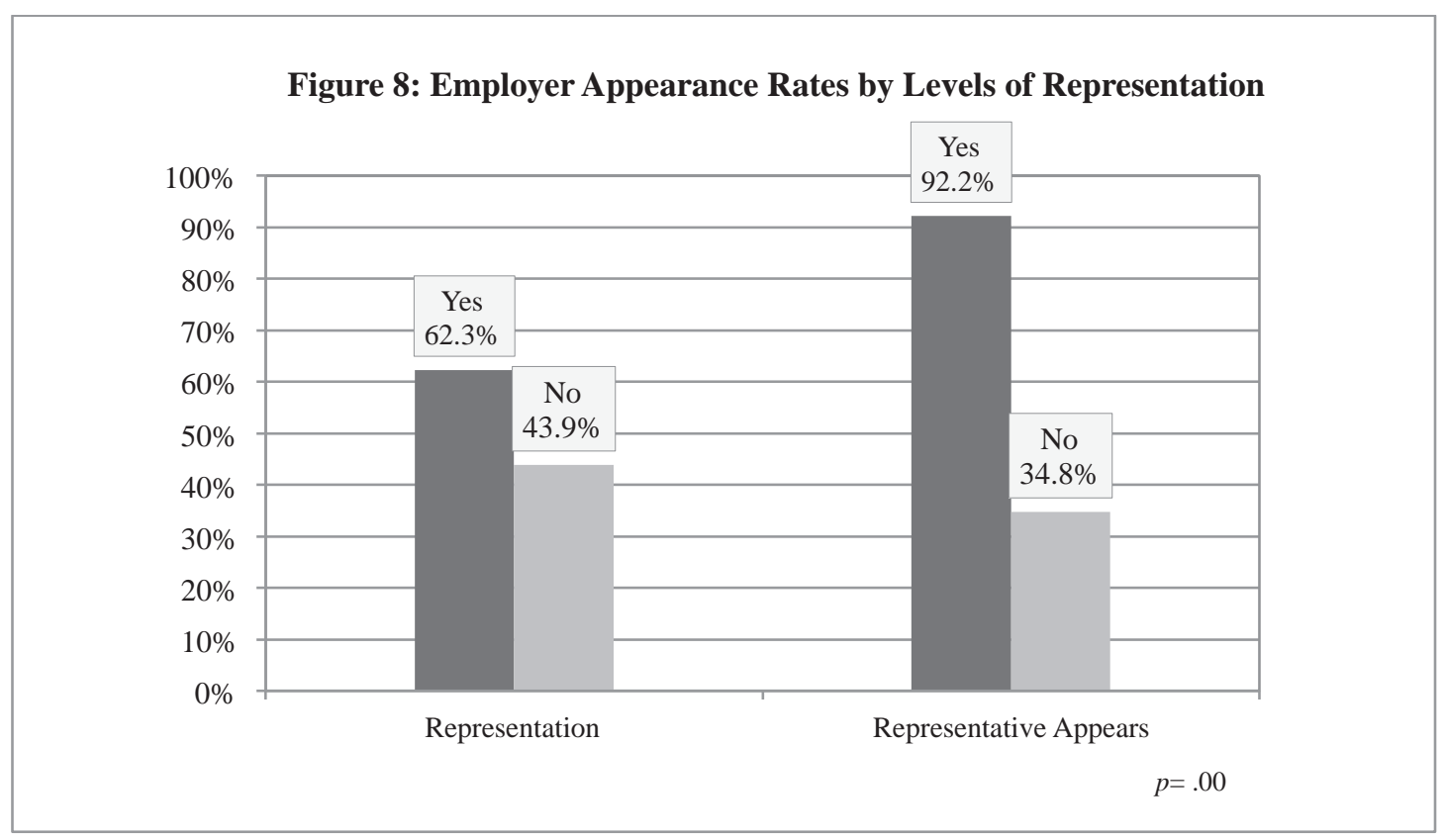

When a claimant has a representative and the claimant appears at the hearing, the win rate for those claimants is nearly statistically significantly higher than for those in the group of represented claimants that do not appear at their hearing, as shown in Figure 9. ${ }^{119}$ Similarly, among represented claimants, when both the claimant and representative appear at a hearing, the claimant has a higher win rate compared to when only the representative appears.

\footnotetext{
${ }^{119}$ Note that represented claimants who appear at their hearing do not necessarily appear with a representative. See supra n. 108 for an explanation of why a party may have a representative of record, but that representative may not appear at the hearing.
} 
Shanahan, Carpenter, \& Mark, Representation in Context

DRAFT - August 11, 2014

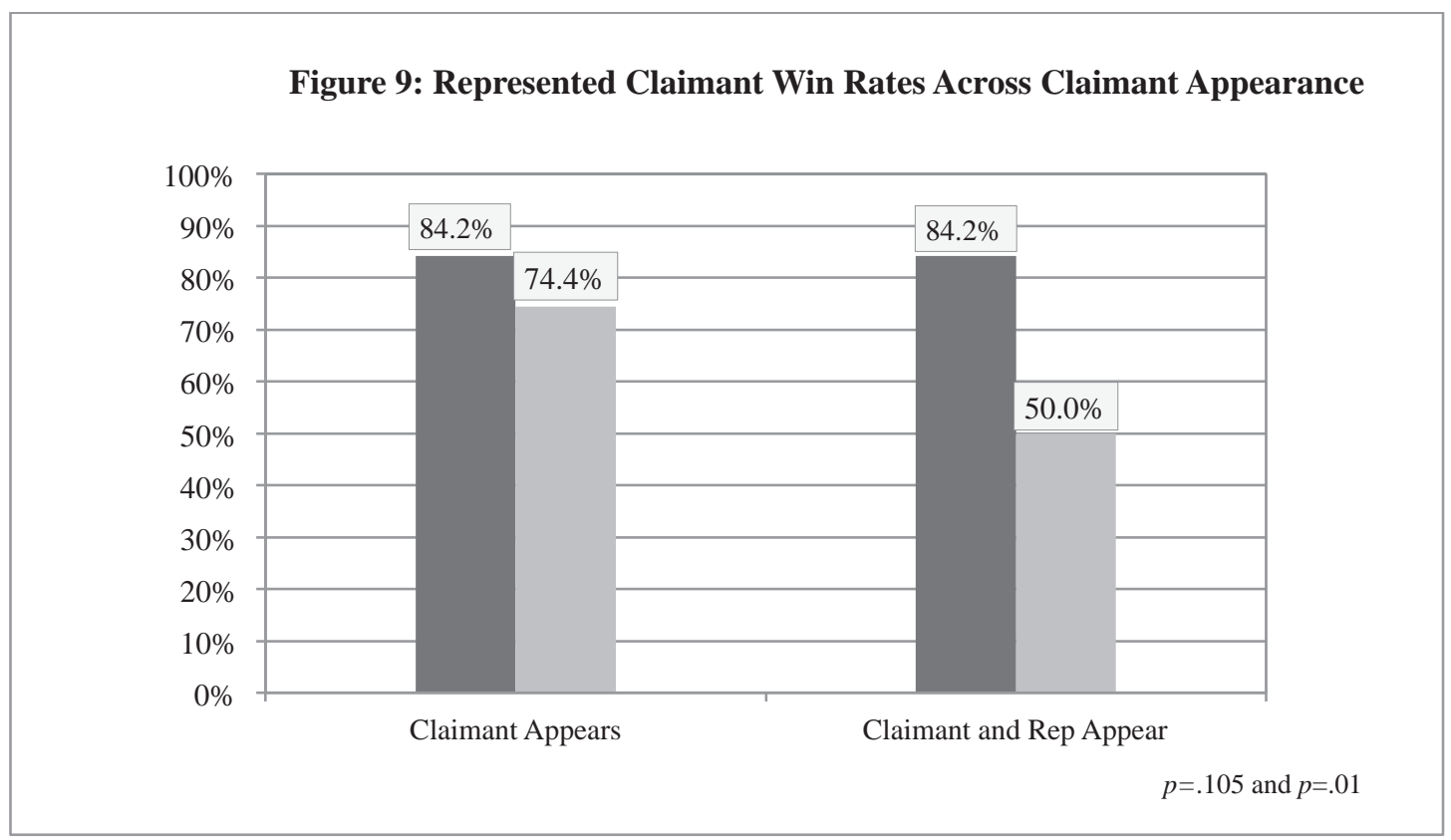

As Figure 10 shows, when represented, employers win at a greater rate when they appear at a hearing, compared to represented employers who do not appear at a hearing. Similarly, when the employer's representative appears, employers who appear with their representative win at a greater rate than employers who do not appear with their representative.

Figure 10: Represented Employer Win Rates Across Employer Appearance

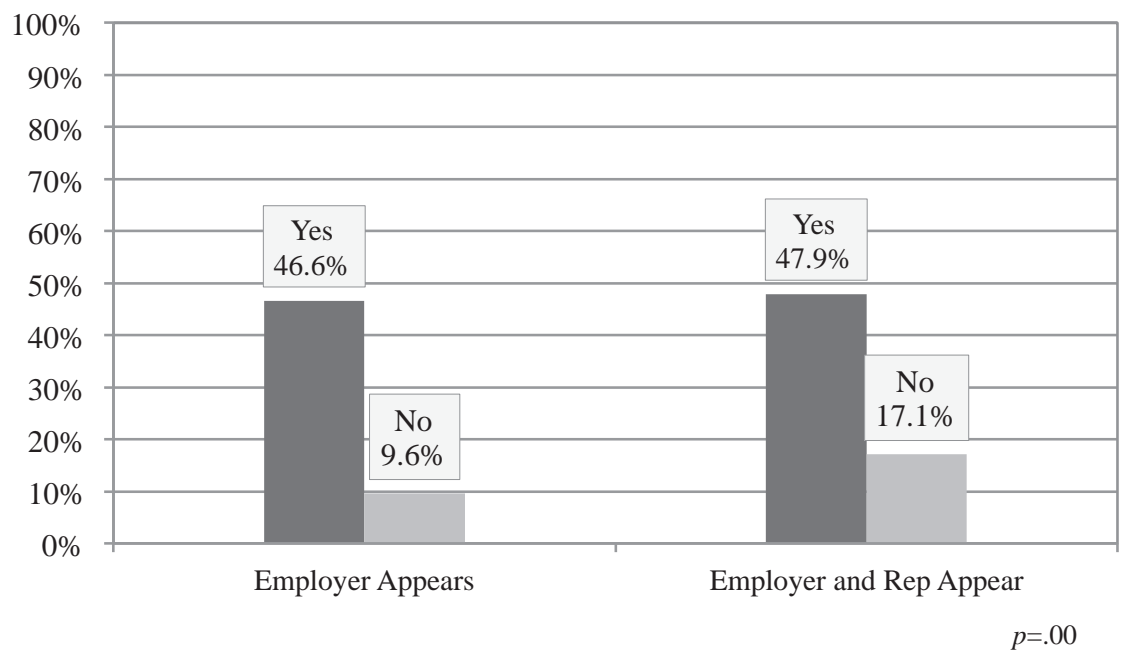


Shanahan, Carpenter, \& Mark, Representation in Context

DRAFT - August 11, 2014

\section{Testimony}

When parties have a representative, they present testimony at different rates compared to those who do not have a representative whether that testimony is by the party or another witness.

Figure 11 demonstrates that when a claimant does not have a representative, the claimant presents testimony a significantly lesser amount of the time than when the claimant has a representative. Among represented claimants, claimants whose representative does not appear present testimony at a significantly lesser rater than when the representative does appear.

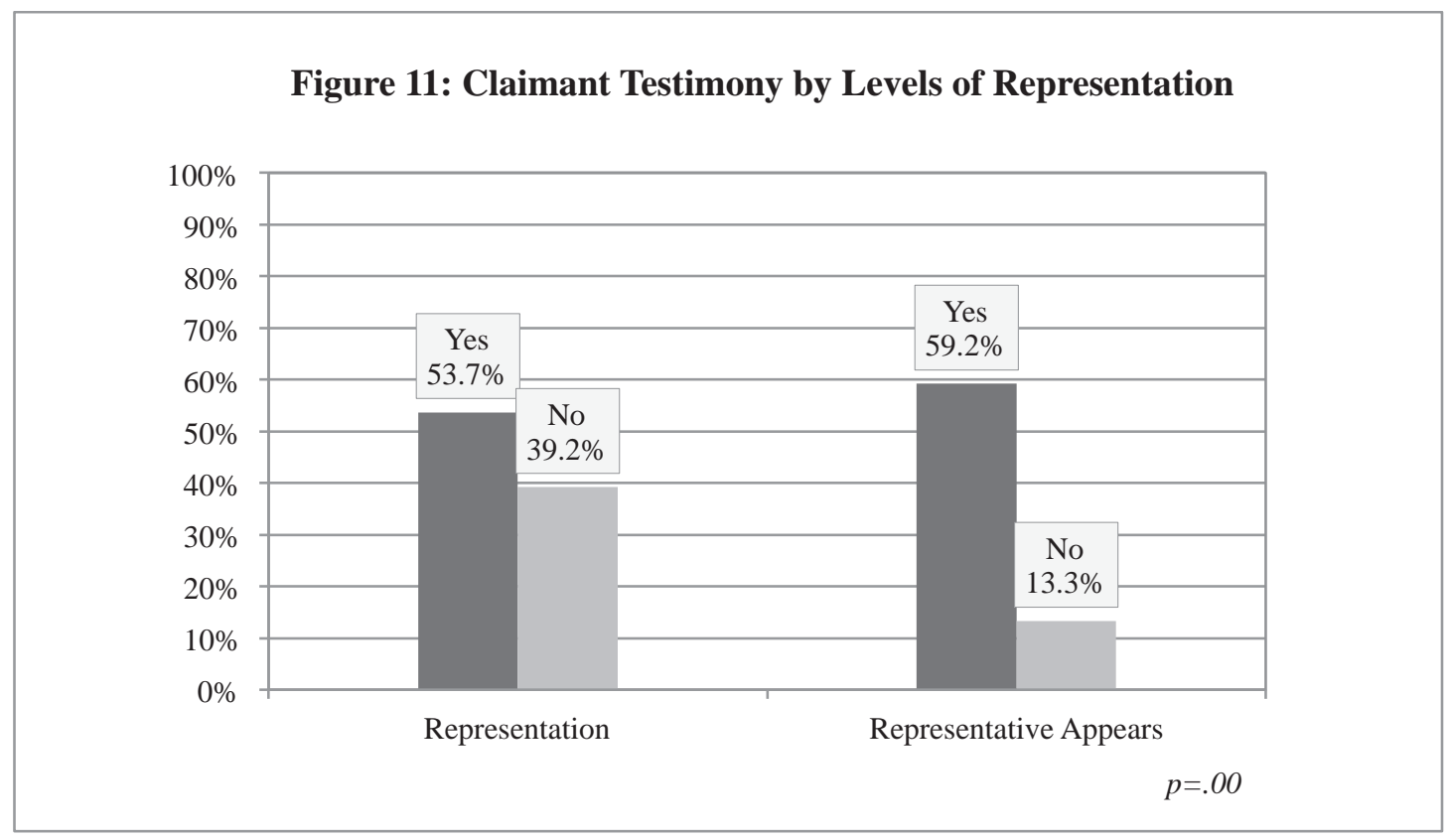

A represented employer presents testimony more often than an unrepresented employer, as shown in Figure 12. Similarly, among represented employers, the frequency of testimony is higher for the group where representation appears as compared to the group where representation does not appear. 


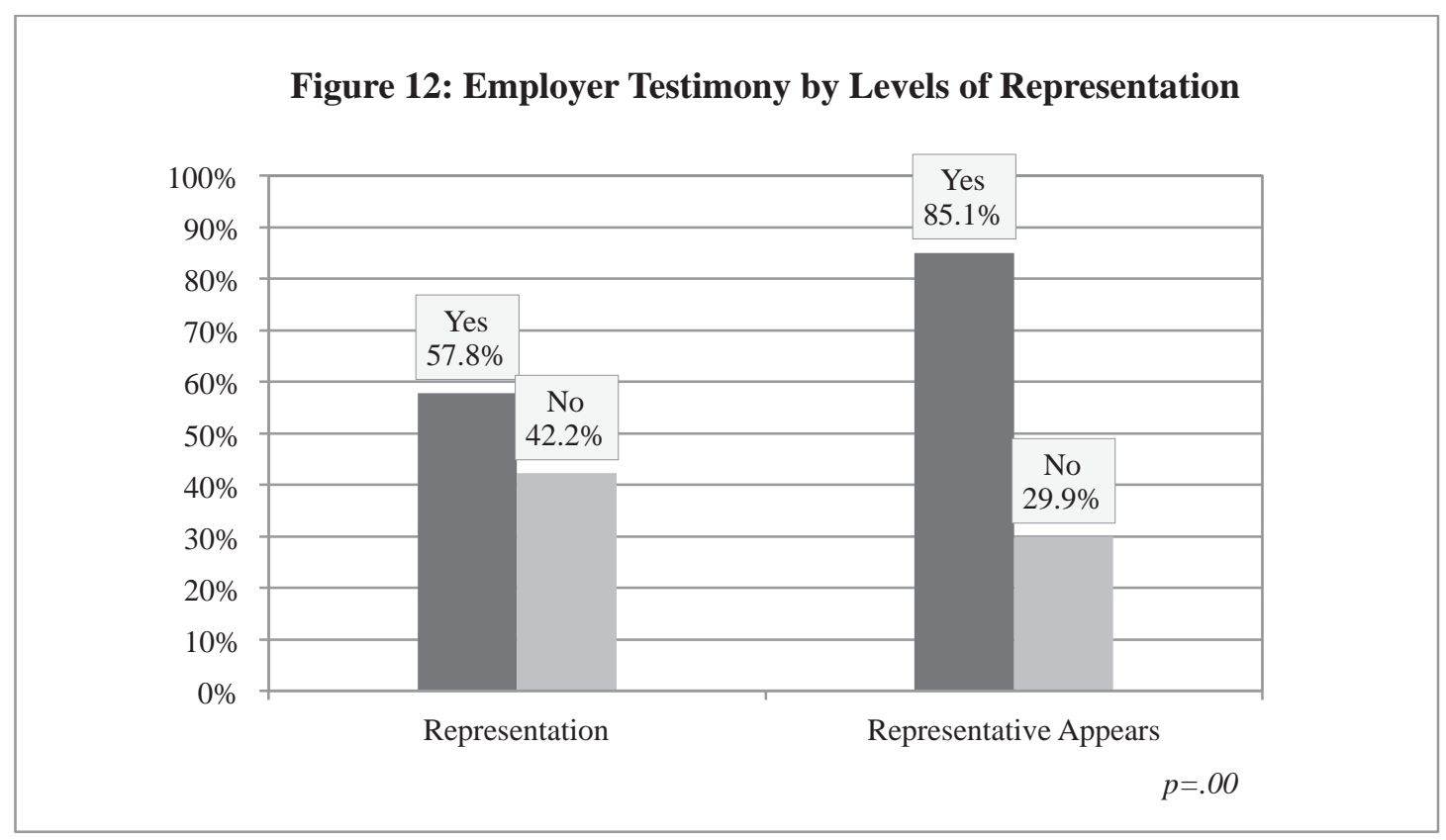

Figure 13 shows that when an unrepresented claimant presents testimony of any kind, there is not a statistically significant difference in the claimant's win rate compared to when an unrepresented claimant presents no testimony. And when a represented claimant presents testimony of any kind, the win rate is $77.5 \%$ compared to represented claimants who present no testimony, who have a win rate of $89.6 \%$. The same is true for claimants whose representative appears. 


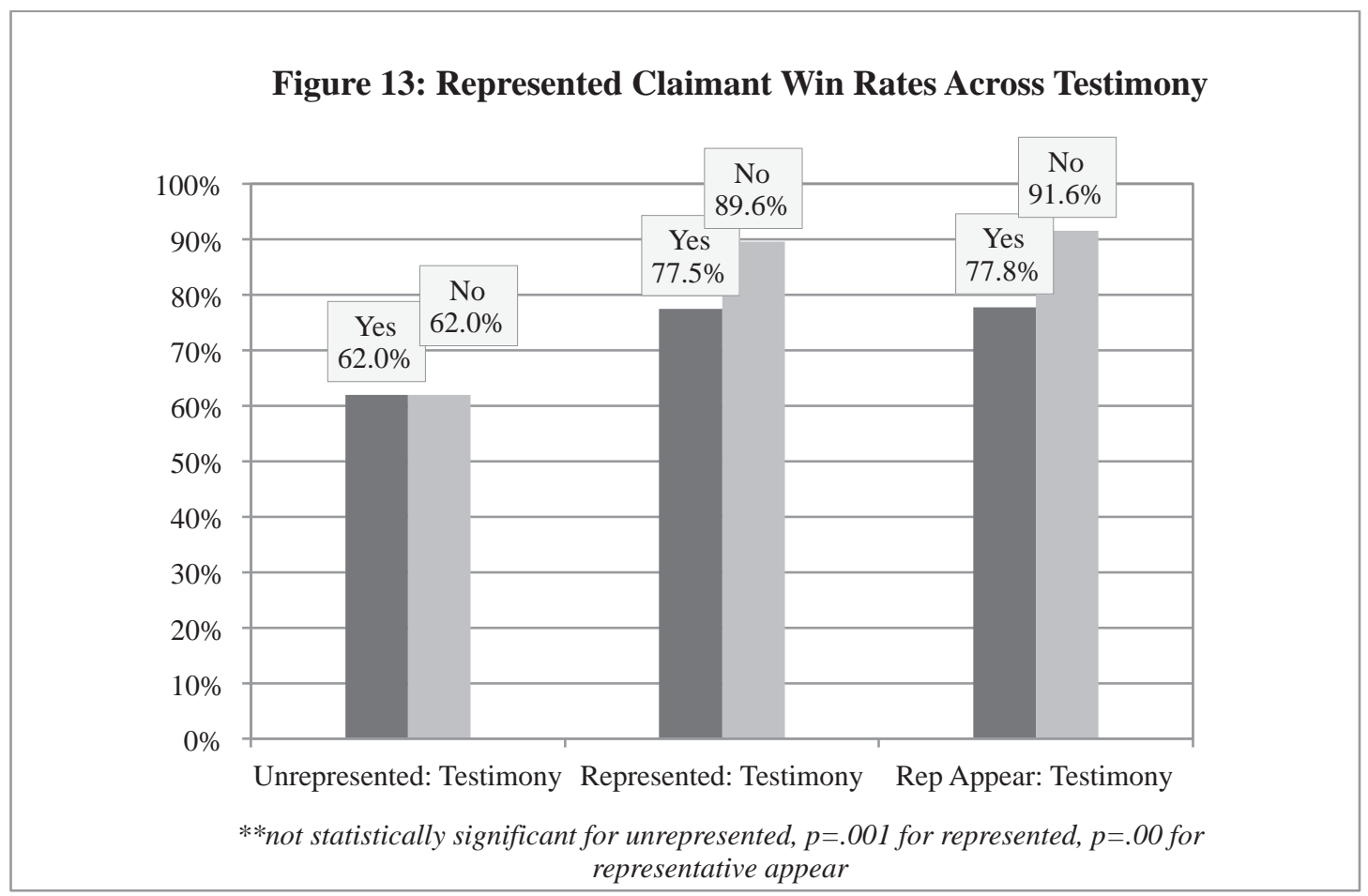

These results can also be observed when testimony is parsed into testimony by the claimant herself and testimony by another witness. When an unrepresented claimant herself testifies, there is not a statistically significant difference in the claimant's likelihood of winning the case. However, when a represented claimant testifies, the claimant wins $77.8 \%$ of the time compared to $94 \%$ of the time if she does not testify. Similarly, when a claimant is represented and has any other witness testify, a claimant's win rate in this group is $77.8 \%$ compared to $91.6 \%$ when a witness does not testify. This relationship is also present when the claimant's representative appears at the hearing; claimants who do not testify have significantly higher win rates than claimants who do testify, winning $95 \%$ of cases compared to $77 \%$ when the claimant testifies.

The analysis of an employer's representation and presentation of testimony demonstrates a different situation, as demonstrated in Figure 14. When an employer is unrepresented, those in the group that present testimony win at a significantly higher rate 
than those in the group that do not present testimony. If an employer is represented, those who present testimony have a higher win rate than those in the group that did not present testimony. And when comparing groups of employers that presented testimony when the representative appeared as opposed to when the employer did not present testimony, there is a similar pattern. ${ }^{120}$

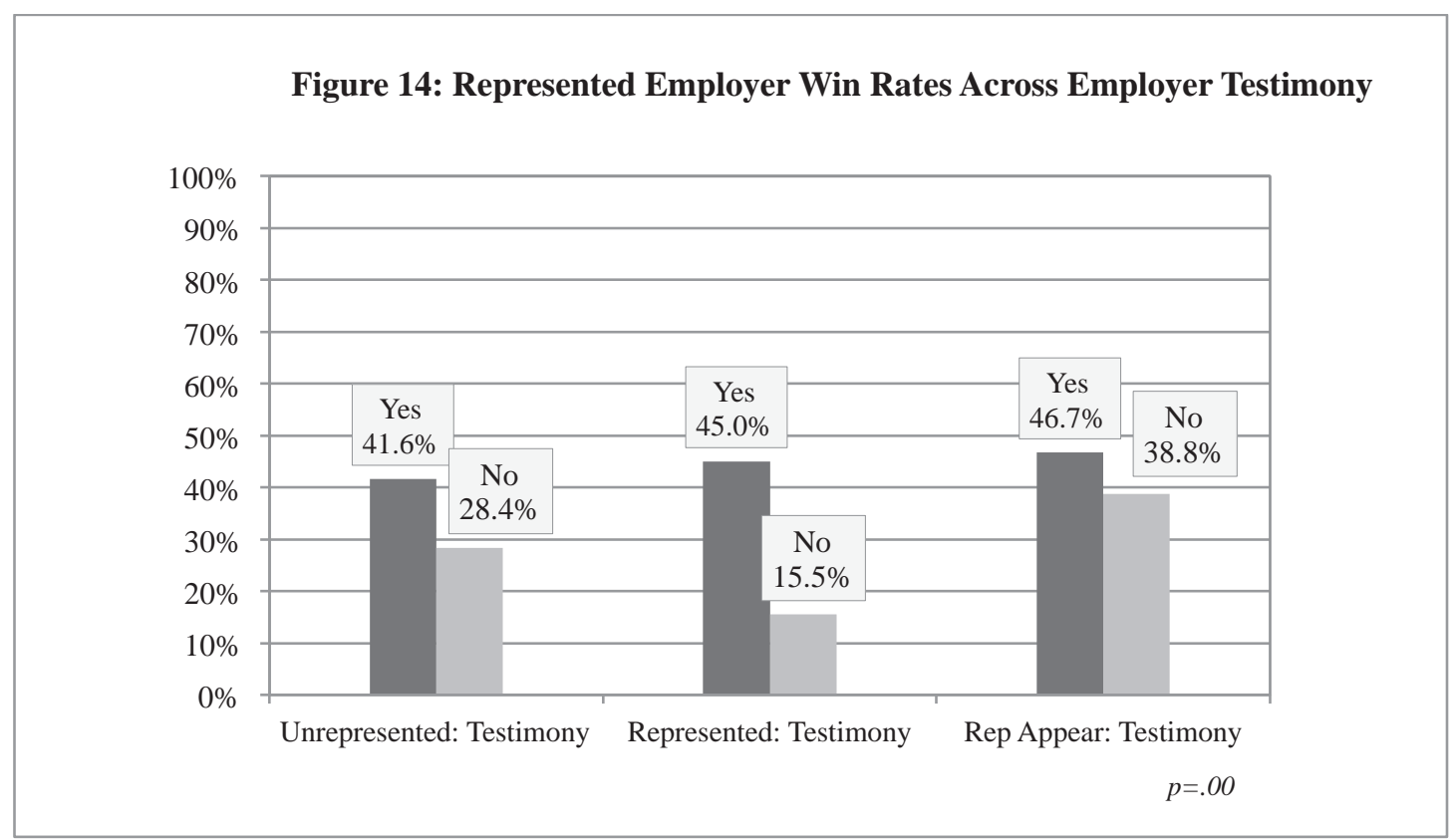

\section{Document Disclosure}

Both represented claimants and represented employers disclose and introduce documents at a higher rate than unrepresented claimants and unrepresented employers. As shown in Figure 15, a significantly greater number of represented claimants disclose

${ }^{120}$ It is not useful to parse employer testimony into testimony by the party as compared to testimony by witnesses because the distinction between the employer "party" and employer "witness" is a fluid one that is not accurately captured in case records. For example, the individuals at a hearing for an employer could be a human resources executive and the employee who supervised the claimant. Depending on these individuals' preferences, one or both of these individuals could testify and either one of them could act as the "party" during the hearing, speaking on behalf of the employer and presenting argument. In contrast, the claimant is easily identifiable as the "party" in the case records. 
documents compared to unrepresented claimants. The same is true of employers, to a greater extent.

Figure 15: Document Disclosure by Levels of Representation

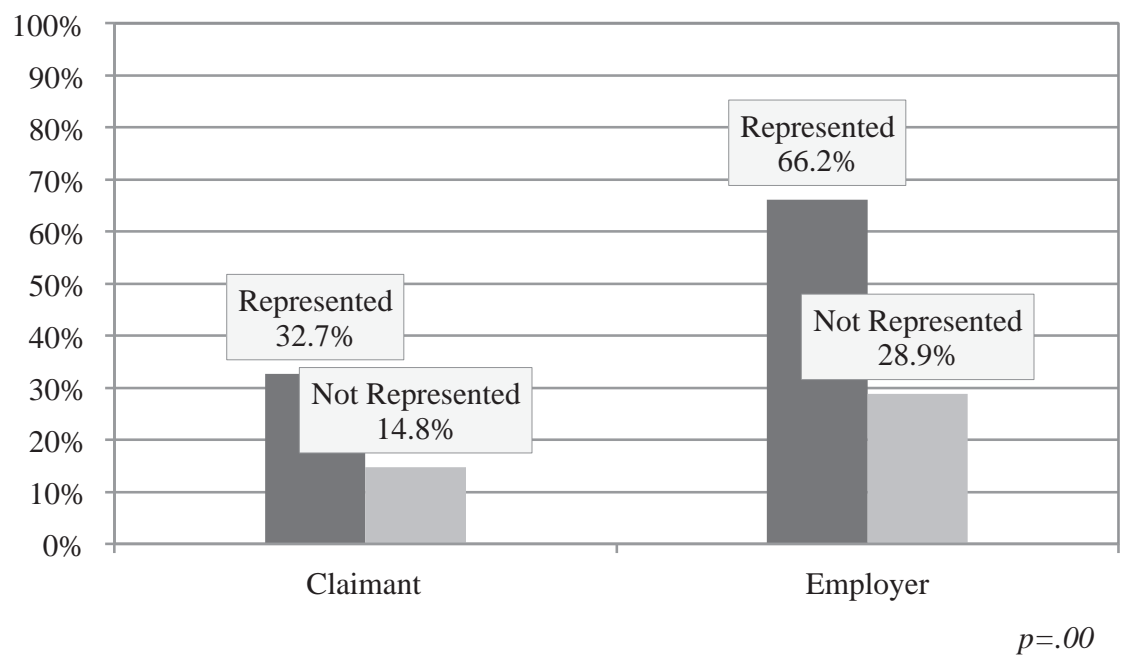

When a claimant is represented, or when a representative appears at a hearing,

there is no statistically significant difference in the claimant's case outcomes based on document disclosure. Represented employers and those whose representative appears have significantly higher win rates when disclosing documents, compared to not disclosing, as shown in Figure 16. Unrepresented employers also have significantly higher win rates when they disclose documents as compared to those unrepresented employers that do not disclose documents. 


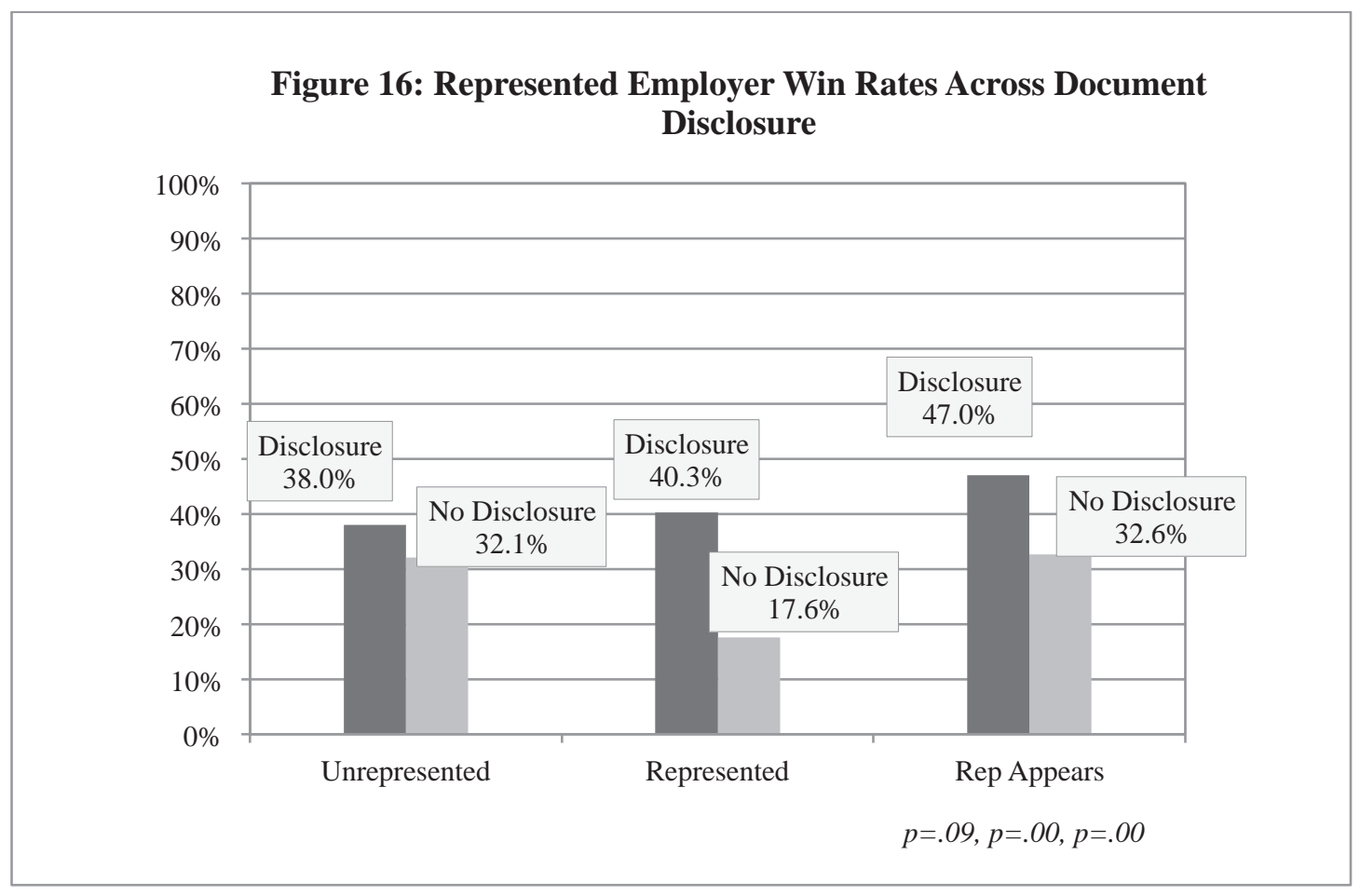

\section{Introduction of Documents}

The introduction of documents follows a similar pattern, with claimants in the represented group introducing documents at a significantly higher rate than unrepresented claimants, as shown in Figure 17. Employers in the represented group also introduce documents at a significantly higher rate as compared to employers that are unrepresented. 
Shanahan, Carpenter, \& Mark, Representation in Context

DRAFT - August 11, 2014

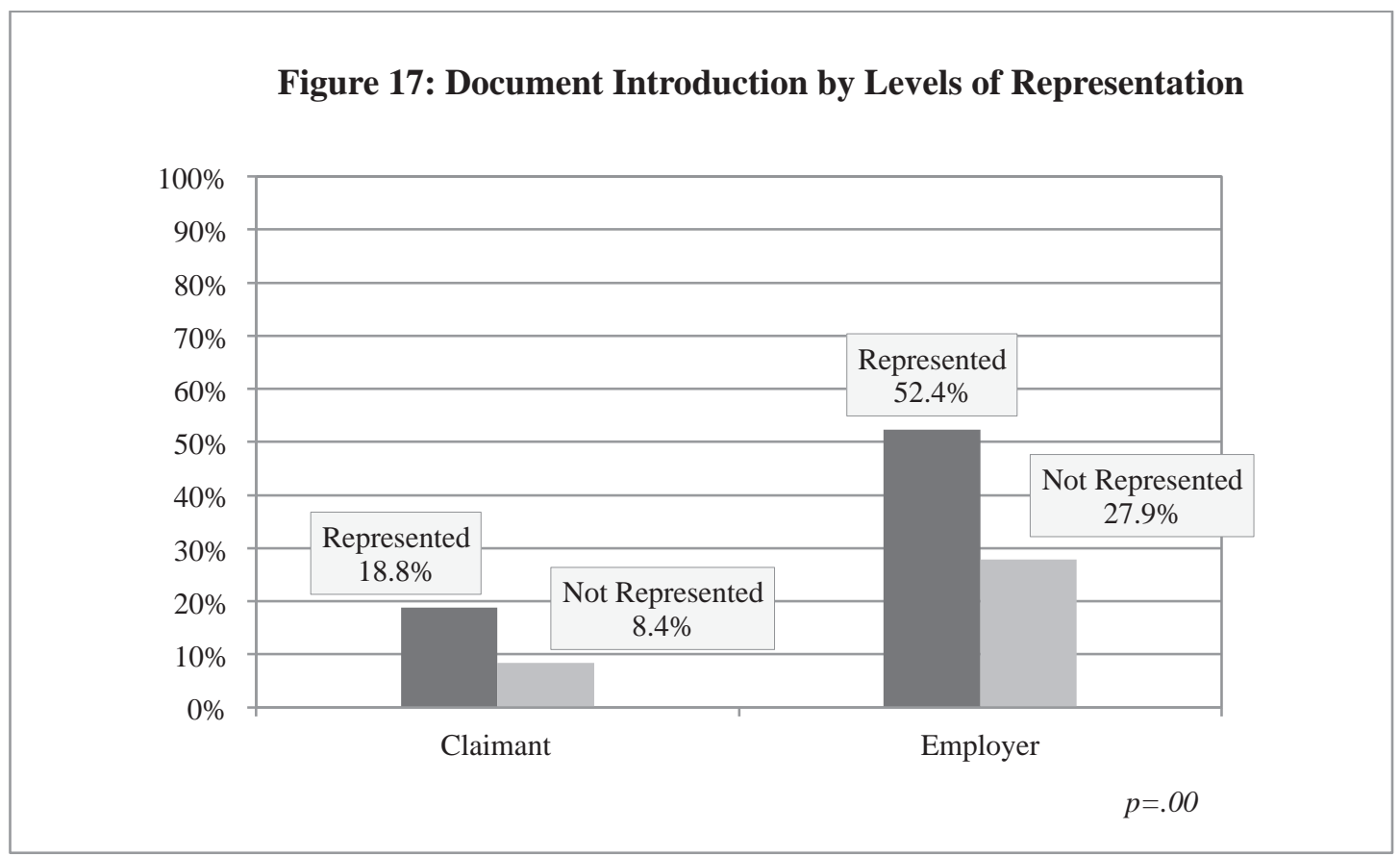

The introduction of documents has a different relationship to case win rates for employers and claimants, as shown in Figures 18 and 19. For unrepresented claimants, represented and claimants whose representative appears, the introduction of documents is associated with a lower win rate, as compared to not introducing documents.

Figure 18: Represented Claimant Win Rates Across Document Introduction

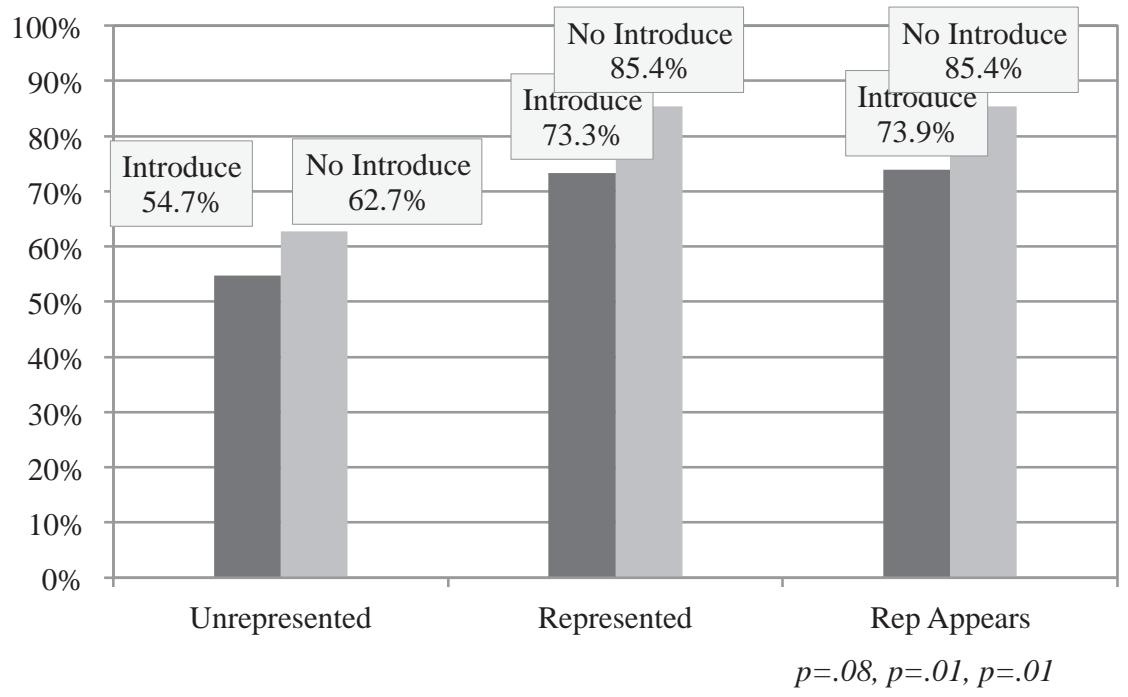


On the other hand, for employers, the introduction of documents is associated with a higher win rate (as compared to the win rates of the groups not introducing documents), for unrepresented and represented employers, but this difference in proportions is not statistically significant in the representative appearance comparison.

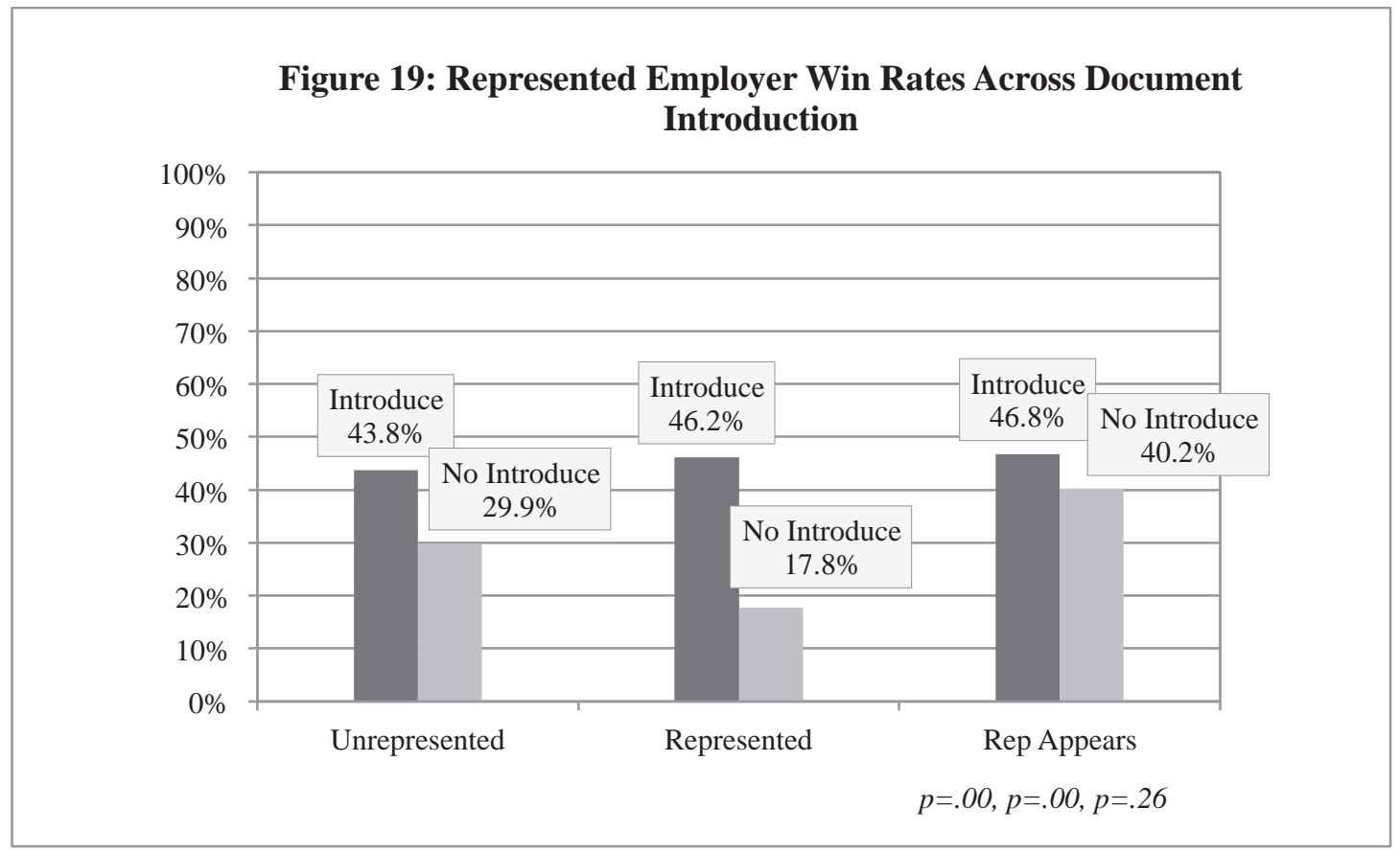

\section{Document Admission}

Finally, documents that are ultimately admitted into evidence follow a similar pattern, with the group of represented claimants having documents introduced $97 \%$ of the time, as compared to $94 \%$ of the time for unrepresented claimants, a difference that is not significant between these groups. Employers that are represented have documents admitted almost $100 \%$ of the time, as compared to the group that is not represented, which has its documents admitted $98 \%$ of the time.

As a result of these high rates of document admission, it is difficult to make comparisons of win rates across document admission categories for claimants and 
employers. While claimants in groups that do not have their documents admitted have significantly lower win rates as compared to those who do have their documents admitted, the likelihood that a claimant would not have their documents admitted is very low across both groups that are represented and groups in which representation appears. There is no statistically significant difference in win rate across claimants that are unrepresented and have documents admitted or not admitted. For employers, there are insufficient observations to compare across document admission categories for those who are represented and those whose representation appears.

\section{Procedures in Combination}

Finally, we combined appearance and the use of the four evidentiary steps described above into a single model to examine whether a party's use of any of these steps is advantageous, and whether it is more or less advantageous for parties in represented groups. Here, we use a binary indicator - claimants and employers are separated into groups based on if they have used any of the five variables or not.

As shown in Figure 20, the win rate for unrepresented claimants that do not appear or use an evidentiary step is not significantly different from the win rate for unrepresented claimants that do use these procedural steps. When these five steps are combined for represented claimants, claimants see slightly, but still not significant, lower win rates when using an evidentiary step as compared to represented claimants who do not use a step.

However, the win rate for unrepresented employers that appear or use evidentiary steps is significantly higher than the win rate for those unrepresented employers who do not use any of these steps, as demonstrated by Figure 21. And the same is true for 
Shanahan, Carpenter, \& Mark, Representation in Context

DRAFT - August 11, 2014

represented employers who see proportionally higher win rates when appearing or using an evidentiary step, compared to represented employers who do not use any of these steps.

Figure 20: Claimant Win Rates Across Combined Procedures

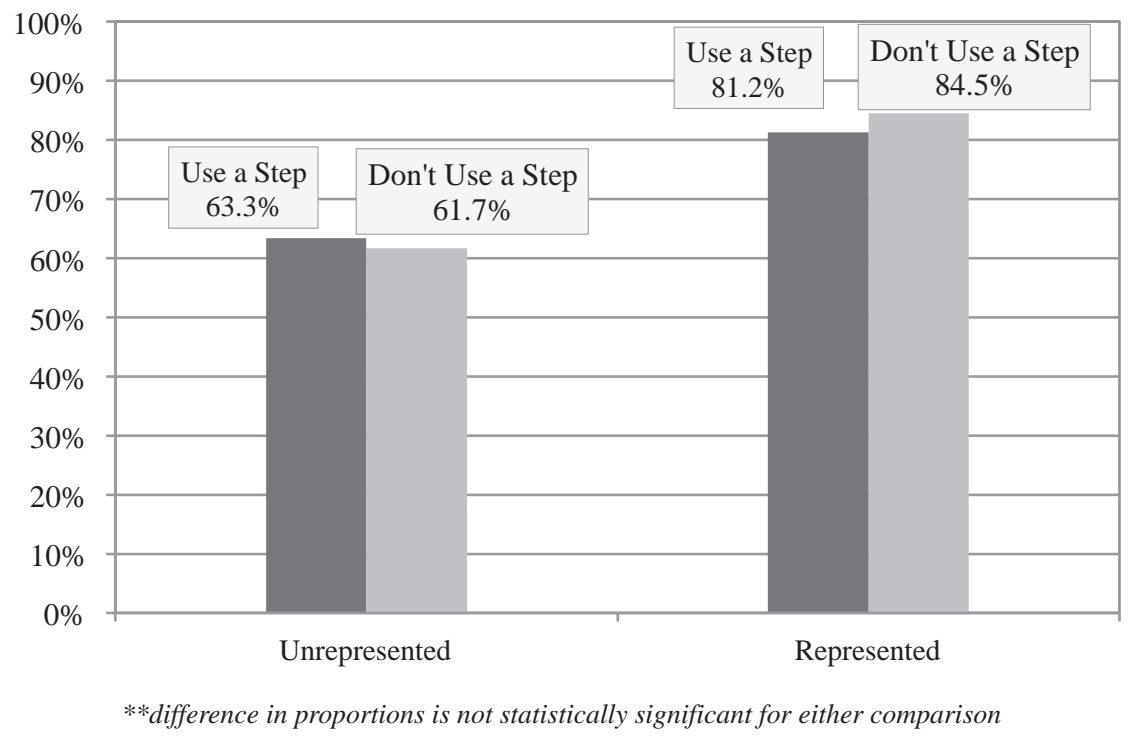

Figure 21: Employer Win Rates Across Combined Procedures

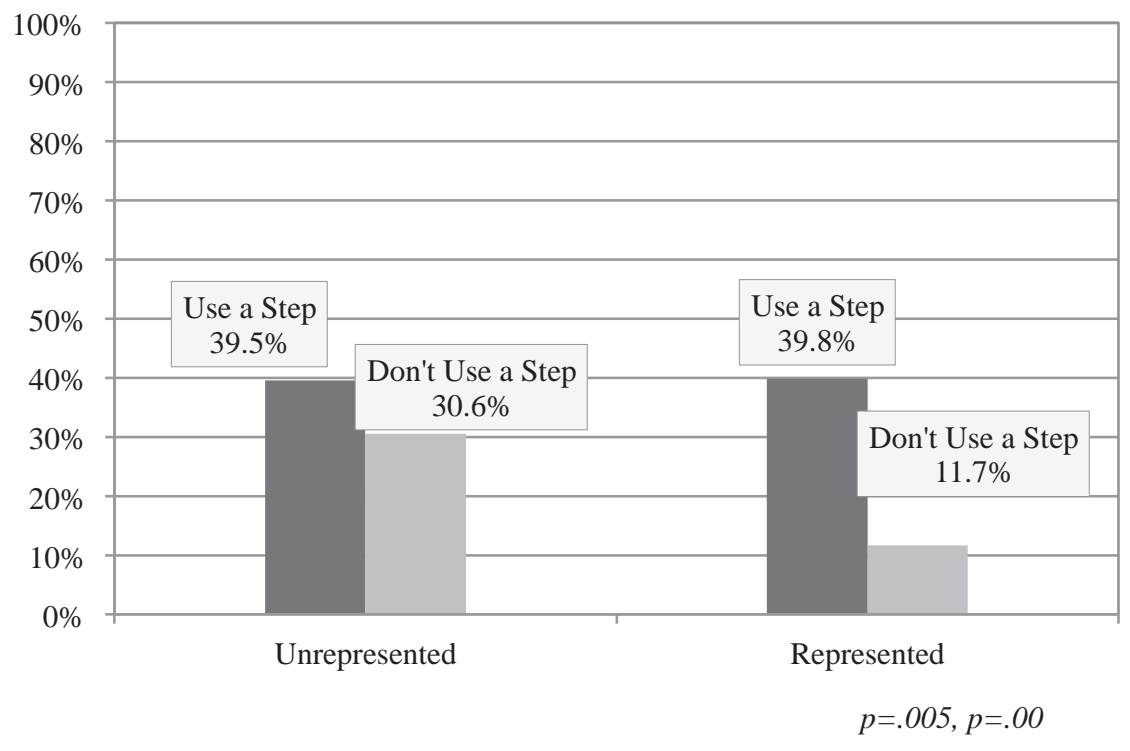




\section{Implications}

Our empirical results are consistent with previous studies and theories of balance of power and expertise, but also highlight the need for expanded theory and research of representation in context. We begin that effort in this section.

Our results reflect the practical reality of the civil justice system in America, one in which the vast majority of low-income Americans represent themselves - often against much more powerful parties - in the "ordinary, everyday cases" that constitute the bulk of the civil justice landscape. ${ }^{121}$ The results similarly support the theory that the civil justice system can reflect and reproduce existing social inequality, just as it can be a site where inequality is challenged. ${ }^{122}$ Where less powerful litigants represent themselves against those with more power, baseline inequities are likely to persist. But where such litigants have legal representation, the opportunity to challenge inequality follows.

\section{A. Representation and Balance of Power}

Our empirical examination of representation in context provides additional understanding of the power dynamics between the parties, and the role of representation in those dynamics. The data support previous studies that have found representation

\footnotetext{
${ }^{121}$ See KRITZER, THE JUSTICE BROKER, supra note 32, at 3. Kritzer offers a comprehensive analysis of lawyers' role in the routine litigation that takes place in America's state and federal civil courts. For a vivid description of the day-to-day operations of an American civil court, see Kat Aaron, The People's Court, The AmericAn Prospect (November 21, 2013). See R. LaFountain, R. Shauffler, S. Strickland \& K. Holt, Examining the Work of State Courts: An Analysis of 2010 State Court Caseloads, NAT'L CTR. FOR STATE COURTS (2012), available at http://www.courtstatistics.org/otherpages/ /media/Microsites/Files/CSP/DATA\%20PDF/CSP_DEC.ashx (last visited March 24, 2014) (finding in a study of seventeen state general jurisdiction courts in 2010,61\% of cases were contract matters, $11 \%$ probate, $11 \%$ small claims, $6 \%$ tort, $2 \%$ real property, $2 \%$ mental health, and $7 \%$ all other civil; this excludes domestic relations cases, which make up $6 \%$ of state cases nationwide). One study found that $62 \%$ of all plaintiff award winners in state courts were awarded \$50,000 or less. Lynn Langton, M.A. and Thomas H. Cohen, Civil Justice Survey of State Courts, 2005, U.S. Dep't of Justice (Oct. 2008) available at http://www.bjs.gov/content/pub/ascii/cbjtsc05.txt (last visited March 26, 2014).

${ }^{122}$ See Sandefur, Race, Class, and Gender, supra note 25, at 346-52 (discussing how race, class, and gender inequalities influence, reproduce, and are challenged by civil justice experiences).
} 
correlates with improved case outcomes for claimants. ${ }^{123}$ More importantly, the data demonstrate that the relationship between representation and case outcomes is more pronounced when the balance of power is introduced into the analysis. Though employers do not see a statistically significant difference in case outcomes when they are represented, they do see higher win rates when they have a representation advantage, as compared to employers that do not have a representation advantage. And while claimants have higher win rates when represented as compared to unrepresented claimants, the proportion of cases claimants win is also higher when claimants have representation imbalanced in their favor, as compared to when representation is balanced.

In the modern American legal system, where civil legal representation is not guaranteed by the state, a more powerful party, such as an employer, is more likely to have the resources to obtain representation, whether it is through an in-house legal department for a large employer or through a third party lay representative retained to control costs for a smaller employer. In this scenario, our data show that the less powerful party, such as a claimant, is at a significant disadvantage. In addition, the lower marginal advantage of representation for employers is consistent with the theory that employers come to the process with greater power - that can often approximate expertise - and thus have less to gain from representation than claimants. Similarly, claimants come to the process with less power and thus have more to gain from representation, whether it is the fact of their own representation, representation when the employer has none, or when both parties are represented.

\footnotetext{
${ }^{123}$ Despite the difference from previous studies in overall claimant success rates, this study's findings that represented claimants, as compared to unrepresented claimants, have a higher proportional win rate than represented employers, as compared to represented employers, is consistent with those studies. See, KRITZER, LEGAL ADVOCACY, supra note 9, at 34; Rubin, supra note 9, at 628.
} 
Notably, when both parties are represented, claimants see a higher proportion of favorable outcomes as compared to when both parties are unrepresented. This last observation highlights the role of party power in any question of representation. A claimant is at a disadvantage when there are no representatives as compared to when both parties have representation. This finding supports the idea that more powerful parties, whether through functional expertise or repeat player advantage or simply greater resources, necessarily have an advantage in the civil legal process. The presence of representation on both sides mitigates this advantage. Where there is no representation, the parties do not have balanced power, but when there is representation for both parties, the parties' power is more balanced. Of course, one limitation of our study is that we do not know why some parties have representation and some do not. There are many reasons why an employer or a claimant may seek or retain counsel, and these reasons are likely to interact with our findings regarding balance of power. We hope that future work explores the interaction of these issues.

These findings support a broader theory - one we hope future research will test: the lower a party's power relative to its opponent, the more it stands to benefit from representation. We argue this is due to the ability of better-resourced parties to use functional equivalents of professional expertise, an ability that is based on a party's resources, social status, education level, and other elements of social and economic power. Thus, as a baseline matter, while some parties have advantages that would otherwise be conferred by representation, others have no such advantage. We propose that this latter group will benefit the most from legal representation, particularly when they face a more powerful opponent. 
Returning to our example, when Wilma faces SGI in her unemployment benefits appeal, there is an obvious disparity in power between the parties. Wilma has never been in the court before; indeed, she has never been in any court. She earned minimum wage working for SGI and has had no income for a month while awaiting a decision on her appeal. Elaine has been in the court many times before. She has a basic understanding of what she must prove to ensure the judge denies the worker's claim for benefits. She knows the type of evidence the judge wants to see. Although she is not a lawyer, she understands the setting and the process well.

In this setting, Elaine would certainly benefit from legal representation. For example, a lawyer would understand that the testimony of a witness is better than assertions contained in a hearsay document. But we argue Elaine will do a fairly good job on her own because she has done it so many times before and learned some things along the way. ${ }^{124}$ In comparison, the relative benefit of legal representation for Wilma is much greater. She has everything to gain from a lawyer's expertise. In addition, the fact of representation may provide Wilma with some psychological comfort and increase in power as the party who has never been to court before. A corollary issue is the symbolic effect of a powerful party. Thus, in our example, SGI's reputation in the community as a significant employer and Elaine's reputation in the court as a regular presence may be another imbalance in power that works against Wilma.

\footnotetext{
${ }^{124}$ We recognize that there is variation in employers and claimants. For example, if Wilma had been a cashier at a store with two employees and the owner, who appears at the hearing, has never been to court before, the role of representation may be different. If the owner, like Wilma, knows nothing about the substantive law, procedures, or formalities of communication in the courtroom, he would also benefit significantly from legal representation. For example, a lawyer might introduce a crucial piece of evidence that the owner would never think to bring. However, for purposes of this project we are relying on the assumption that employers, in general, are more sophisticated and appear in court more frequently than claimants. It is our hope that future research will test our findings and theories through a more detailed examination of parties' sources of power.
} 
The data support the intuitive result that a representative who appears at a hearing - as opposed to simply being the representative of record - is correlated with a higher proportion of favorable case outcomes for both parties and that this is also true where representation is imbalanced in that party's favor. And as with representation generally, the represented claimant sees a significantly higher win rate when a representative appears, while represented employers do not see a significant difference. This is consistent with theories of power and expertise. A representative who appears is more likely to affirmatively act on behalf of a party than a representative who is only of record. Though, it is important to note that the data show that representation without appearance still confers some advantage. We argue that this is because representatives can still provide expertise without appearing at a hearing - by helping the party select which evidence is important to disclose or introduce, by shaping case theory or testimony, by explaining substantive or procedural law, or through other means An area for future exploration is clarifying the mechanisms of expertise outside of the hearing, and investigating how this expertise affects a party's case outcomes.

A final issue raised by this analysis is whether and how the type of representation affects the represented party's advantage. For example, in this sample employers have non-lawyer representatives in $38 \%$ of all cases while claimants have non-lawyer representatives, mostly student attorneys, in $2 \%$ of all cases. Other studies have shown that non-lawyer representatives are less effective than lawyer representatives. ${ }^{125}$ This suggests a number of questions for future research. Do non-lawyer representatives help parties less than lawyers? Does this analysis change relative to the power of the

${ }^{125}$ KRITZER, LEGAL AdvOCACY, supra note 9, at 76-77. 
represented party or the balance of representation in the case? Could the high proportion of non-lawyer representation explain this article's finding that employers gain less advantage from representation than claimants? What is it that lawyers do for a party, as compared to what non-lawyers do, that makes them more helpful? What is the nature of non-lawyer expertise vs. lawyer expertise? These questions naturally tie to questions of strategic expertise. If, as we theorize, lawyers contribute strategic expertise in a way that lay representatives cannot, then the data should bear this out. Employers with attorneys who show up should win more than employers with lay representatives, and this should be especially true when these representatives appear at the hearing. These questions of representative type are especially important for our civil legal system. We continue to struggle with achievable ways to provide civil litigants with effective access to legal systems, and we continue to debate solutions ranging from guaranteed attorney representation to limited legal advice to self-help resources. Yet we are trying to create change without understanding which of these types of representation is effective in which contexts. Thus, understanding representation type in context is a crucial part of this conversation and a future article will focus on these questions.

In addition to questions of representative type, our findings present a variety of avenues for future research, some of which we hope to address using our larger three year data set. One set of questions concerns how the characteristics of a case interact with the balance of power and representation. For example, in unemployment cases, the burden of proof varies depending on the theory of the case, and so we hope to explore how this variable interacts with the balance of power and representation. Similarly, it may be that which party appeals is a significant variable in this analysis. In addition, is there a way to 
measure the factual strength of a case to explore the interaction of that variable with balance of power and representation?

Another set of questions concerns how parties come to have representation. Qualitative research into the selection criteria representatives use to take clients may help us understand selection in context, as might qualitative research into how employers and claimants come to seek out or obtain representation. Further, developing controlled or randomized study designs that take these factors into account will enhance our understanding of this important component of representation in context.

A final set of questions concerns the sources of parties' power, and how they affect the balance of power between the parties. One identified source of power is substantive law, in this study the burden of proof is an example of this source of power for a claimant and her representative. An area for future research is theorizing a typology of sources of power and how these sources of power are different in different legal contexts. Another source of power is procedural rules, and this source of power may shift depending on how representatives and parties use it. For example, a representative who makes frequent use of a procedure that has not been previously used may shift the balance of power in that legal setting. Thus another area for future research is the existence of these sources of power, and how use of them by representatives shifts the balance of power between the parties. We hope that these questions can inform the rich, ongoing effort to empirically examine representation, and can deepen this inquiry to help us understand representation in context. ${ }^{126}$

\footnotetext{
${ }^{126}$ See, e.g., Jiménez, Dalié and Greiner, D. James and Lupica, Lois R. and Sandefur, Rebecca L., Improving the Lives of Individuals in Financial Distress Using a Randomized Control Trial: A Research and Clinical Approach, 20 Georgetown Journal On Poverty LAw \& POLICY 449 (2013).
} 


\section{B. Representation, Use of Procedures, and Strategic Expertise}

The parties' use of procedural steps provides additional insight into the strategic choices of each party and the role representation plays in these choices. Our findings confirm our hypothesis that expertise correlates with use of procedural steps, but also present the surprising result that this use of procedures by representatives does not necessarily correlate with better case outcomes.

One overarching observation is that employers are more likely to take advantage of appearing at the hearing and evidentiary steps. This can be explained in two different ways. First, the employer has the initial burden in quit cases and the entire burden in misconduct cases and, as a result, must show up and use testimony or documents to make its case. Thus, it is unsurprising that employers are more likely to appear and take advantage of the mechanisms for introducing evidence. Second, employers, whether represented or not, are more likely to be sophisticated or repeat player actors and thus more likely to be aware of and take advantage of procedural mechanisms.

Another overarching theme in the data is that represented parties on both sides appear, introduce testimony, and disclose, introduce, and admit documents at higher rates, as compared to unrepresented parties. At a surface level, this is a logical result because if representatives have more procedural expertise, then a represented party would be expected to engage in these steps more than an unrepresented party. In addition, the frequency with which employers use procedures - whether represented or not underscores the theory of how parties' inherent power interacts with the expertise contributed by a representative. In this data, the employer uses most of the studied procedures most of the time - and the rate is slightly higher when the party is represented. 
This is consistent with the theory that employers come to these cases with sophistication and repeat player experience that places them in an advantageous position, regardless of representation. Thus, as borne out by the data on representation and case outcomes, an employer wins marginally more cases when represented, as compared to employers who are not. A represented employer that discloses, introduces, or admits documents has more favorable case outcomes compared to employers that do not use these procedural steps. Similarly, when a represented employer presents testimony, the employer's favorable case outcomes are higher as compared to represented employers that do not present testimony. When appearance and evidentiary steps are combined, unrepresented employers who use any of these steps have higher win rates than unrepresented employers who do not use any of these procedural steps, and the same is true - to an even greater extent - for represented employers.

However, the analysis of the relationship between use of procedures and the party's case outcome reveals a more complicated picture. Our analysis of balance of power argues that claimants have more to gain from representation because they begin in a position of less power and sophistication. The data showing significant differences in use of procedures when a claimant is represented as compared to when she is not represented is consistent with this theory. However, our results also reveal the surprising result that when a represented claimant uses some of these steps, the claimant's win rate is lower than when the represented claimant does not those same procedures.

The data show that a represented claimant who presents testimony or discloses, introduces, or admits documents is associated with a lower proportion of favorable case outcomes as compared to represented claimants who do not use these same steps. 
Represented claimants who disclose documents have the same case outcomes as represented claimants who do not disclose. But represented claimants who introduce or admit documents win fewer cases than unrepresented claimants who do not use these steps. The same is true when the claimant presents testimony, and is exaggerated when the claimant testifies. The only exception to this pattern of worse case outcomes with increased procedural participation is when the claimant appears at the hearing. When all of the procedures are analyzed together, neither represented claimants nor unrepresented claimants see significant differences in case outcomes with the use of any procedure as compared to not using any procedure. This result - contrary to our hypothesis - suggests that claimant representatives' use of procedures is in some way not effective and raises important questions about the value of representation and the type of representation necessary to have a positive effect on a party's outcome.

There are a number of potential explanations for this surprising finding, and we argue that our new theory of lawyers' strategic expertise illuminates a number of these explanations. One explanation for this finding is that the substantive legal context of our study - where the burden of proof is placed entirely on the employer in misconduct cases and initially on the employer in voluntary quit cases - creates disincentives for a claimant to use procedural steps to introduce evidence. In these cases, a claimant wins when an employer introduces no evidence. Thus, any use of procedures to introduce evidence by a represented claimant holds the inherent risk of weakening the presumption in the claimant's favor. Claimant representatives may choose to introduce documents in "closer" cases or cases where the representative perceives the case as unlikely to win and thus is simply using every procedure. Alternatively, it may be that represented claimants are 
more likely to use procedures to introduce evidence where the employer has already presented a strong case, and the representative perceives the need to introduce more evidence to counter the perceived or real lower likelihood of winning the case. Relatedly, when a representative uses a procedure to introduce evidence, there is a risk that the lawyer goes too far and introduces more evidence than is necessary to advance the claimant's case theory, ultimately weakening the claimant's case.

Another explanation may be the judge's perception of procedural activity by a claimant representative. It may be that, because employers have the burden of proof and especially when employers or their representatives are repeat players before a particular judge - a judge perceives a represented employer's use of procedures to introduce evidence as a signal that the employer has a strong case. But the judge may similarly perceive a represented claimant's use of procedures as a sign of a weak case, interpreting introducing evidence when the burdens of proof do not require it as a desperate measure. A more cynical explanation may be that a judge may not be used to claimants having representatives, and the shift in procedural dynamics that results from a lawyer in the courtroom creates a negative perception by the judge of the claimant's case.

This pattern of better outcomes for represented employers who use procedures, and worse outcomes for represented claimants who use procedures, and the potential explanations for this pattern, suggest that there is more to understand about how power and expertise function in civil justice settings. Each of these explanations underscores that representatives choose to use procedural steps to introduce evidence in context, and that for a representative to be effective, she must understand and adapt to this context. We argue that our findings and the potential explanations for them suggest that the 
advantage provided by representation only occurs when the representative acts strategically. Thus, a representative who reflexively uses procedures - such as having a claimant testify when the claimant does not have the burden - may hurt the party. In contrast, a representative who strategically uses procedures - such as keeping a claimant from testifying so that the claimant does not help the employer meet its burden - is more likely to help the party. This is especially true for the party without the burden - usually the claimant - as a representative for an employer that has the burden is more likely to improve outcomes by using any procedure. Similarly, a representative for a claimant who uses a procedure based on unsound strategic judgment is more likely to worsen outcomes because the presentation of evidence may carry the employer's burden and thus worsen the claimant's case.

Thus we propose a third theoretical component of representative's expertise: strategic expertise. This third component of strategic expertise complements existing theories of substantive and relational expertise. ${ }^{127}$ Specifically, strategic expertise is the ability to synthesize the rule-based and principled knowledge that characterizes substantive expertise with the understanding of people and human interaction that characterizes relational expertise and the ability to exercise judgment in applying this synthesis to a particular client's circumstance. This concept of strategic expertise explains what lawyers do to connect formal training with situational understanding and supplement it with strategic thinking and judgment as they serve their clients. Where substantive expertise is abstract, rule-based, and learned primarily through formal training, and relational expertise is grounded in relationships and learned through

${ }^{127}$ See supra notes 31-40 and accompanying text. 
experience, strategic expertise involves the knowledge, judgment, and skill lawyers

employ when making decisions based on a synthesis of inputs gleaned from substantive and relational expertise. ${ }^{128}$ Strategic expertise involves combining knowledge of the underlying legal framework with the particularities of a given civil legal setting, including individual personalities and preferences, and exercising judgment to apply this knowledge to a particular client's circumstance.

Revisiting Wilma's case illustrates how lawyers employ strategic expertise. Imagine Wilma and Elaine have lawyers for the hearing, and during the hearing Elaine is testifying about Wilma's tenure as an employee of SGI. Elaine is asked a question about Wilma's habit of lending money to fellow employees - a topic that is not relevant under the rules of evidence. In the moment that she hears the question, Wilma's lawyer has a decision to make: does she make a relevance objection? Her substantive expertise in the law of evidence tells her that the statement may be inadmissible and that most judges would sustain an objection. She knows the case well enough to anticipate the answer, one that she believes is not damaging for her case if it comes in (again, drawing on her substantive expertise regarding what she must prove to win the case). Turning to her relational expertise, she knows that this judge has little patience for objections as a general matter, and she has already objected on a number of issues that concern her more

${ }^{128}$ Others have attempted to define legal strategy and strategic decision-making in a variety of ways. See, e.g., David R. Barnhizer, The Purposes and Methods of American Legal Education, 36 J. LEGAL PROF. 1, 66 (2011) (differentiating strategic awareness from both substantive law and "judgment, analysis, synthesis and problem-solving" as an essential focus for legal education); Angela Olivia Burton, Cultivating Ethical, Socially Responsible Lawyer Judgment: Introducing Multiple Lawyering Intelligences Paradigm into the Clinical Setting, 11 CLINICAL L. REV. 15, 42 (2004) (observing that "strategic intelligence" is essential in exploring scenarios and choosing effective courses of action and differs from personal, narrative, logicalmathematics, categorizing and linguistic intelligences, which together contribute to a lawyer's "critical judgment”); Richard K. Neumann, On Strategy, 59 FordHAM L. REV. 299, 345 (1990) (defining legal strategy as a composition of legal tactics based upon fundamental principles such as "concentration of effort on a hypothesized decisive event, planning from that event backward in time to the present, generating the largest number of reasonable strategic options from which to choose"). 
than this particular question. She also believes that if she objects, the judge may read it as a sign of weakness in her client's case. The attorney also knows that Wilma is confident in her advocacy and will not be concerned if she does not object to this question. In the mere seconds that she has to make this decision, she weighs all of the inputs from her substantive and relational knowledge and skill and considers how they interact to impact her chance for overall success in the case. She decides there is a greater risk to objecting than there is to letting the answer in. Thus, although an objection would be a legally and procedurally accurate choice, one that would likely have been sustained by the judge, her understanding of the human dynamics in the room, combined with the substantive legal issues in her case, and her strategic understanding of the choice presented led her to not object. $^{129}$

Strategic expertise is the hallmark of quality legal representation and is inextricably linked with good judgment and zealous representation. It is the expertise that lawyers draw on when making bold choices or taking calculated risks in their work. It comes into play when a lawyer pushes the boundaries of the law to make a novel legal argument; when a lawyer presents the facts of her client's case in a way that reflects not only the merits of the case but also her impressions of the jury; when a lawyer chooses to make a lengthy closing argument before a visibly impatient judge, based on the calculation that the legal and factual issues are too complex to forego thorough treatment;

\footnotetext{
${ }^{129}$ Kritzer's concept of process knowledge, described supra note 30, includes a lawyer's understanding of how a given legal setting typically operates, for example, knowledge about the hearing process for a particular type of case, including the process in a particular court. Our concept of strategic expertise includes the understanding of the operation of a given legal setting that is captured in Kritzer's process knowledge, but strategic expertise expands process knowledge to capture a lawyer's contextualized decision-making, which takes into account her knowledge of "typical process" as well as what this knowledge means for the specific case, client, and issue she is handling, and ultimately, how the synthesis of this information will inform her choices.
} 
or when a lawyer chooses to disclose information to an opposing party because she believes it will lead to a favorable settlement, even when the disclosure is not required by formal legal procedures. Unlike substantive or perhaps even relational expertise, only a representative can provide a party with strategic expertise. While a judge may be able to explain a legal concept or procedure to a pro se party, and an unbundled service provider may be able to tell a claimant to speak slowly before a certain judge, only a representative who is in a hearing with a party and knows the party's case can lend strategic expertise at a given moment.

The idea that lawyers employ strategic expertise makes explicit what is implicit in the existing literature on lawyers' professional expertise: that there is a constant interaction and tension between the substantive and the relational in legal work and that this interaction produces different actions in different contexts. To effectively solve problems and make decisions for her client, a lawyer will use her training and experience in substantive law and procedure to determine what legal principles and rules apply in a given case. She will also consider what she knows about the people she will interact with in the context of that case and the relationship dynamics she must navigate. Then she will consider how the two sets of information interact with one another given the context of the particular case and exercise judgment in choosing her actions on behalf of her client. This process characterizes the exercise of strategic expertise.

This theory of strategic expertise is consistent with the sociological theory that a lawyer's effect is primarily about helping a party navigate procedures and forcing a court 
to follow its own rules. ${ }^{130}$ However, our view is that a lawyer using strategic expertise may push a court to enforce its own rules if that is the strategically advantageous choice in a particular factual and legal context. But it is just as likely that a lawyer makes the choice to not encourage the enforcement of a rule because that is the strategically sound choice for that client in that context.

Strategic expertise, like relational expertise, is not necessarily taught in any formal context. ${ }^{131}$ It is perhaps sometimes innate or developed from non-professional experiences, but it is typically gained and developed through professional experience. It is situated and highly contextual, but it includes a deep appreciation for legal and procedural complexity. It also includes an appreciation of risk and the ability to weigh costs and benefits of choices. It necessarily involves judgment. Sometimes, strategic choices require an attorney to ignore social and cultural cues in favor of a principled legal position. Sometimes, strategy requires a lawyer to ignore legally incorrect moves by judges or opposing counsel in favor of preserving relationships. It is the expertise that guides a lawyer in choosing her battles wisely. In many ways, it is the essence of effective problem-solving; it combines an appreciation of legal frameworks, an understanding of the human context in which law operates, and effective contextual judgment, and it is thus an essential component of a lawyer's professional expertise. Future research can provide more insight into our theory of strategic expertise. We hope to use future studies of this data set to explore this theory in several ways. First, analysis regarding the type of case may provide more insight into the use of procedures

${ }^{130}$ See Sandefur, Elements of Expertise, supra note 24, at 4; Sandefur, Impact of Counsel, supra note 8, at 74 (describing empirical evidence suggesting that "part of what lawyers do to affect litigation outcomes may be assisting people in managing procedural complexity").

131 Though, like relational expertise, clinical legal education and other experiential curricular approaches are opportunities for law students to develop strategic expertise. 
and strategic expertise. It may be that claimants' use of procedures to introduce evidence in a quit case - where the claimant bears part of the burden of proof - have a different relationship to case outcomes than in a misconduct case - where the employer bears the entire burden. And if there is not variation in the use of procedures and case outcomes, that may provide important insight into whether representatives for claimants are in fact contributing strategic expertise that translates to effective representation. An additional layer of analysis could also include which party files the appeal, as this may help understand the party's interest in the case or motivation to use procedures.

Analysis of procedures other than those used to introduce evidence may reveal additional insights into representation and expertise. Is there a difference between those procedures that happen in a hearing and those that happen outside the hearing, such as motion practice? Does expertise function differently with regard to procedures that do not implicate the burdens of proof, such as a motion to continue as compared to a motion to dismiss on the merits? Does analysis of how expertise actually functions pose critical questions about theories of client-centeredness and how a lawyer should enable her client's voice and narrative in the legal process?

In addition, analysis of the variation in actors may reveal different insights. Does expertise function differently for different representative types? Are there differences in how expertise functions for individual representatives within a given category of representatives? Does it function differently for representatives who are repeat players as compared to those who are not? Do different individual judges or their backgrounds result in different case outcomes relative to use of procedures? Some of these questions may be answered by additional analysis of this data set, and some may be understood 
better through qualitative research such as case observation or interviews with representatives and judges.

Thus, the data analyzed in this article leaves us with two conclusions. The first is that the balance of power and representation between the parties is as important to consider as the fact of whether a single party has representation. Without examining the balance of power, we cannot truly understand the effectiveness of representation. The second is that the expertise a representative lends to a party's experience is nuanced and complex. While a representative is likely to increase a party's engagement in the legal process, the fact of having a representative, by itself, does not necessarily lend the expertise necessary to improve a party's case outcome. And increased engagement in process, by itself, does not necessarily improve outcomes. Our theory of strategic expertise and our results demonstrate that beyond the fact of having a representative, it is what that representative does that really matters for a party. And we need additional research - in this study and others - to understand these components of representation in context.

\section{Conclusion}

We cannot understand civil justice outcomes, party experiences, or the role of representation without an appreciation of context. This article begins a conversation about the context in which representation operates. The questions we raise regarding the balance of power and the role of expertise can be explored across a range of civil justice settings, from other administrative courts, to immigration proceedings, to municipal and

state district courts. These issues can and should be explored in other areas of substantive 
law, particularly those affecting the vast majority of litigants in American courts, such as housing, family, and consumer law.

The questions of imbalance of power and representation explored in this article highlight that we should investigate other factors that might be at play in the civil justice system. For example, are there party characteristics that might further refine our understanding of balance of power? Similarly, does the type of representation play a role in the balance of power between parties? In addition, does the type of case make a difference in the balance of power? For example, does a case with less balanced burdens of proof - like a misconduct case in our data - counteract the balance of power or representation between the parties? Or does a case with the government as the opposing party present a different balance than when the employer is the opposing party?

The role of representative expertise, which leads to increased engagement in the legal process but which can, paradoxically, lead to worse case outcomes when exercised inappropriately, also suggests areas for future inquiry. Does the use of procedure and its success vary by the type of representative? Is a lawyer more successful than a nonlawyer at using procedures, thus suggesting that lawyers do contribute unique, or at least less common, strategic expertise? Are there characteristics of parties that can predict the functional expertise the party wields without representation? Does the type of case change the expertise dynamic? Is it more or less important to have a lawyer's expertise when you are a party with the burden or a party without the burden? Similarly, does this expertise operate differently in cases where the party on the other side is the government as opposed to an employer? Are a representative's actions outside the hearing important to the analysis of expertise? Are there procedures representatives use more and with 
more success - such as pretrial motions, requests for continuances, or requests for phone hearings - that have different relationships to case outcomes than procedures in the hearing? Finally, what is the influence of a representative's case selection on this analysis?

An additional area of inquiry is how the presence of representation in a particular court or type of case might itself impact the dynamics of power balance and expertise. Put another way: when representatives are repeat players in a legal context, does that presence create systemic change that alters or reduces the need for representation? Are there types of cases - in our data and generally - where representation has been consistently present, and are there measurable changes in behavior or outcomes in those cases even when representation is now no longer present?

Finally, what is the role of judges in analyses of representation in context? What role does the judge play in exacerbating or mitigating the balance of power and representation between the parties in the hearing? If one party is unrepresented, does the judge - intentionally or unintentionally - change her behavior to level the playing field? How does strategic expertise - and particularly the absence of it - affect a judge's perception of a party and that party's case outcomes? Does the presence or absence of a representative exercising strategic expertise interact with the judge's procedural or substantive choices in the hearing? Are judges appropriate and effective actors in mitigating an imbalance of power or lack of expertise?

All of these questions for future exploration underscore the central concept of this project: to understand when, how and why representation matters, we must engage in the complexity of the legal process and parties' experiences in it. The corollary to embracing 
complexity in our research efforts is understanding how these questions and their empirical results affect the reality of the civil justice system. What do the concepts of balance of power and expertise mean for access to justice in practice?

We do not believe that our findings tell us that representatives do not help less powerful parties. In fact, the data shows that, overall, representatives can and do help less powerful parties. But there are some things that some representatives do that may not be helpful in certain contexts. Thus, we think the appropriate conclusion is that representation is not monolithic. Different legal contexts call for different types of representation, and for representatives making different strategic choices. A little representation may not be enough to make a difference. But we cannot assume representation needs based on partial information. Instead, we need to understand how the balance of power and expertise interact with the particular legal context, and how that translates to the role of representation. It may be that our theories of strategic expertise lead to the conclusion that lay representation, unbundled services, court reform, or technology based services are the most effective solutions for particular legal contexts. Similarly, it may be that our understanding of the balance of power leads to the conclusion that some legal contexts are (or can be designed to be) ones where the parties are on equal footing and thus representation is unnecessary or, at the least, a poor use of limited resources. It also may be that some legal contexts require full representation because limited representation or non-representative assistance from courts does not provide enough expertise to offset an imbalance in power. It is clear, though, that we do not yet understand these phenomena enough to know these contexts when we see them. 
And we do not have enough understanding to reliably predict when representation will matter.

Beyond the specific questions about representation raised in this article, this research project and others like it add to our base of knowledge and understanding regarding the real-world operation of civil justice in America—a necessary step in solving problems facing the civil justice system. Despite the recent resurgence of interest in access to justice issues, there is still much that we do not know about how the civil justice system actually operates. ${ }^{132}$ Even in the face of ongoing conversations about the crisis in civil justice among those who work in the trenches of legal services and on access to justice research, it is all too clear that we do not yet have the theory, the data, or the analysis needed to change our civil justice system for the better. Studies such as this one advance our understanding of the nuanced dynamics of legal representation and legal processes in context. Just as importantly, this work also increases our understanding of what is actually happening, on a day-to-day basis, in our nation's civil courts.

${ }^{132}$ See Albiston \& Sandefur, supra note 1, at 117-120 (identifying a lack of information about the demand for civil legal services including how individuals understand and interact with law and the justice system). 
Shanahan, Carpenter, \& Mark, Representation in Context

DRAFT - August 11, 2014

\section{APPENDIX A}

\section{TABLES FOR METHODOLOGY SECTION}

Table M1. Use of Procedures

\begin{tabular}{cccccc} 
& Party Appear & Testimony & Disclose & Introduce & $\begin{array}{c}\text { Admit when } \\
\text { Introduce }\end{array}$ \\
\hline \multirow{2}{*}{ Claimant } & 1180 & 762 & 336 & 192 & 183 \\
& $65.8 \%$ & $42.5 \%$ & $18.7 \%$ & $10.7 \%$ & $95.3 \%$ \\
\hline \multirow{2}{*}{ Employer } & 950 & 888 & 850 & 718 & 713 \\
& $53.0 \%$ & $49.5 \%$ & $47.4 \%$ & $40.2 \%$ & $99.3 \%$ \\
\hline \hline
\end{tabular}

Table M2. Win Rates with Use of Procedures

\begin{tabular}{cccccc} 
& Party Appear & Testimony & Disclose & Introduce & $\begin{array}{c}\text { Admit when } \\
\text { Introduce }\end{array}$ \\
\hline Claimant & 903 & 506 & 241 & 119 & 117 \\
Wins & $76.5 \%$ & $66.4 \%$ & $71.7 \%$ & $61.9 \%$ & $63.9 \%$ \\
\hline Employer & 430 & 388 & 337 & 326 & 326 \\
Wins & $45.3 \%$ & $43.7 \%$ & $39.7 \%$ & $45.4 \%$ & $45.7 \%$ \\
\hline \hline
\end{tabular}

Table M3. Representation Balance

\begin{tabular}{lcc|cc} 
& Represented & $\begin{array}{c}\text { Only } \\
\text { Represented }\end{array}$ & $\begin{array}{c}\text { Representation } \\
\text { Balance }\end{array}$ \\
\hline \multirow{2}{*}{ Claimant } & 398 & 171 & Both & 227 \\
& .221 & .095 & Represented & 0.126 \\
\hline \multirow{2}{*}{ Employer } & 887 & 660 & Neither & 736 \\
& .494 & .367 & Represented & 0.41 \\
\hline Total & 1285 & 831 & & 963 \\
\hline \hline$N=1794$ & &
\end{tabular}


Shanahan, Carpenter, \& Mark, Representation in Context

DRAFT - August 11, 2014

\section{TABLES FOR FINDINGS SECTION}

Table 1: Claimant Win Rates and Representation

\begin{tabular}{lcc} 
& Claimant Represented & Claimant Unrepresented \\
\hline \multirow{2}{*}{ Claimant Wins } & 331 & 866 \\
& $83.2 \%$ & $62.0 \%$ \\
\hline \multirow{2}{*}{ Employer Wins } & 67 & 530 \\
& $16.8 \%$ & $38.0 \%$ \\
Total & 398 & 1396 \\
& $100.0 \%$ & $100.0 \%$ \\
\hline \hline
\end{tabular}

$N=1794$, difference in proportions statistically significant at .00 level $(z=-$

$$
\text { 7.82) }
$$

Table 2: Employer Win Rates and Representation

\begin{tabular}{lcc} 
& Employer Represented & Employer Unrepresented \\
\hline \multirow{2}{*}{ Claimant Wins } & 597 & 600 \\
& $67.3 \%$ & $66.2 \%$ \\
\hline \multirow{2}{*}{ Employer Wins } & 290 & 307 \\
& $32.7 \%$ & $33.8 \%$ \\
Total & 887 & 907 \\
& $100.0 \%$ & $100.0 \%$ \\
\hline \hline
\end{tabular}

$N=1794$, difference in proportions not statistically significant $(z=.50)$

Table 3: Claimant Win Rates and Representation Advantage

\begin{tabular}{lcc} 
& $\begin{array}{c}\text { Claimant Representation } \\
\text { Advantage }\end{array}$ & Both Parties Represented \\
\hline \multirow{2}{*}{ Claimant Wins } & 151 & 180 \\
& $88.3 \%$ & $79.3 \%$ \\
Employer Wins & 20 & 47 \\
& $11.7 \%$ & $20.7 \%$ \\
\hline \multirow{2}{*}{ Total } & 171 & 227 \\
& $100.0 \%$ & $100.0 \%$ \\
\hline \hline
\end{tabular}

$N=398$, difference in proportions statistically significant at .001 level $(z=-2.38)$

Table 4: Employer Win Rates and Representation Advantage

\begin{tabular}{lcc}
\hline & $\begin{array}{c}\text { Employer Representation } \\
\text { Advantage }\end{array}$ & Both Parties Represented \\
\hline \multirow{2}{*}{ Claimant Wins } & 417 & 180 \\
& $63.2 \%$ & $79.3 \%$ \\
\hline \multirow{2}{*}{ Employer Wins } & 243 & 47 \\
& $36.8 \%$ & $20.7 \%$ \\
\multirow{2}{*}{ Total } & 660 & 227 \\
& $100.0 \%$ & $100.0 \%$ \\
\hline \hline
\end{tabular}


Shanahan, Carpenter, \& Mark, Representation in Context

DRAFT - August 11, 2014

$N=887$, difference in proportions statistically significant at .00 level $(z=-4.48)$

Table 5: Win Rates and Representation Balance

\begin{tabular}{lcc} 
& Neither Party Represented & Both Parties Represented \\
\hline \multirow{2}{*}{ Claimant Wins } & 449 & 180 \\
& $61.0 \%$ & $79.3 \%$ \\
\hline \multirow{2}{*}{ Employer Wins } & 287 & 47 \\
& $39.0 \%$ & $20.7 \%$ \\
\multirow{2}{*}{ Total } & 736 & 227 \\
& $100.0 \%$ & $100.0 \%$ \\
\hline \hline
\end{tabular}

$N=963$, difference in proportions statistically significant at .00 level $(z=-5.06)$

Table 6: Win Rates Across Appearance Balance

\begin{tabular}{lcc|cc} 
& $\begin{array}{c}\text { Claimant } \\
\text { Representative }\end{array}$ & $\begin{array}{c}\text { Both } \\
\text { Appear Advantage }\end{array}$ & $\begin{array}{c}\text { Employer } \\
\text { Representative } \\
\text { Appentatives } \\
\text { Appear }\end{array}$ & $\begin{array}{c}\text { Both } \\
\text { Representatives } \\
\text { Appear }\end{array}$ \\
\hline Claimant & 67 & 88 & 12 & 88 \\
Wins & $90.5 \%$ & $71.5 \%$ & $41.3 \%$ & $71.5 \%$ \\
\hline Employer & 7 & 35 & 17 & 35 \\
Wins & $9.4 \%$ & $28.4 \%$ & $58.9 \%$ & $28.4 \%$ \\
\hline \multirow{2}{*}{ Total } & 74 & 123 & 29 & 123 \\
& $99.9 \%$ & $99.9 \%$ & $100.2 \%$ & $99.9 \%$ \\
\hline \hline
\end{tabular}

Table 7: Claimant Appearance Rates by Levels of Representation

\begin{tabular}{lcc|cc} 
& $\begin{array}{c}\text { Claimant } \\
\text { Represented }\end{array}$ & $\begin{array}{c}\text { Claimant } \\
\text { Unrepresented }\end{array}$ & $\begin{array}{c}\text { Claimant } \\
\text { Representative } \\
\text { Appears }\end{array}$ & $\begin{array}{c}\text { Claimant } \\
\text { Representative } \\
\text { Does Not Appear }\end{array}$ \\
\hline $\begin{array}{l}\text { Claimant } \\
\text { Appears }\end{array}$ & 355 & 825 & 343 & 12 \\
\hline Claimant & $89.1 \%$ & $59.1 \%$ & $97.7 \%$ & $26.7 \%$ \\
Does Not & 43 & 570 & 8 & 33 \\
Appear & $10.8 \%$ & $40.9 \%$ & $2.2 \%$ & $73.3 \%$ \\
Total & 398 & 1396 & 351 & $100.0 \%$ \\
\hline \hline
\end{tabular}

Table 8: Employer Appearance Rates by Levels of Representation

\begin{tabular}{lcc|cc} 
Employer & Employer \\
Represented & Unrepresented & $\begin{array}{c}\text { Employer } \\
\text { Representative } \\
\text { Appears }\end{array}$ & $\begin{array}{c}\text { Employer } \\
\text { Representative } \\
\text { Does Not Appear }\end{array}$ \\
\hline $\begin{array}{l}\text { Employer } \\
\text { Appears }\end{array}$ & 552 & 397 & 415 & 185 \\
\hline
\end{tabular}


Shanahan, Carpenter, \& Mark, Representation in Context

DRAFT - August 11, 2014

\begin{tabular}{lcc|cc}
$\begin{array}{l}\text { Employer } \\
\text { Does Not }\end{array}$ & 334 & 508 & 35 & 347 \\
Appear & $37.6 \%$ & $56.1 \%$ & $7.8 \%$ & $65.2 \%$ \\
\hline \multirow{2}{*}{ Total } & 887 & 905 & 450 & 532 \\
& $99.9 \%$ & $100.0 \%$ & $100.0 \%$ & $100.0 \%$ \\
\hline \hline
\end{tabular}

$N=1794$, difference in proportions statistically significant at .00 level $(z=-7.81)$

$N=982$, difference in proportions statistically significant at .00 level $(z=-18.39)$

Table 9: Represented Claimant Win Rates Across Claimant Appearance

\begin{tabular}{|c|c|c|c|c|}
\hline & Claimant Appears & $\begin{array}{c}\text { Claimant Does Not } \\
\text { Appear }\end{array}$ & $\begin{array}{c}\text { Claimant and Rep } \\
\text { Appear }\end{array}$ & $\begin{array}{l}\text { Claimant and Rep } \\
\text { Do Not Appear }\end{array}$ \\
\hline Claimant & 299 & 32 & 289 & 5 \\
\hline Wins & $84.2 \%$ & $74.4 \%$ & $84.2 \%$ & $50.0 \%$ \\
\hline Employer & 56 & 11 & 54 & 4 \\
\hline Wins & $15.7 \%$ & $25.5 \%$ & $15.7 \%$ & $50.0 \%$ \\
\hline \multirow{2}{*}{ Total } & 355 & 43 & 343 & 8 \\
\hline & $99.9 \%$ & $99.9 \%$ & $99.9 \%$ & $100.0 \%$ \\
\hline
\end{tabular}

Table 10: Represented Employer Win Rates Across Employer Appearance

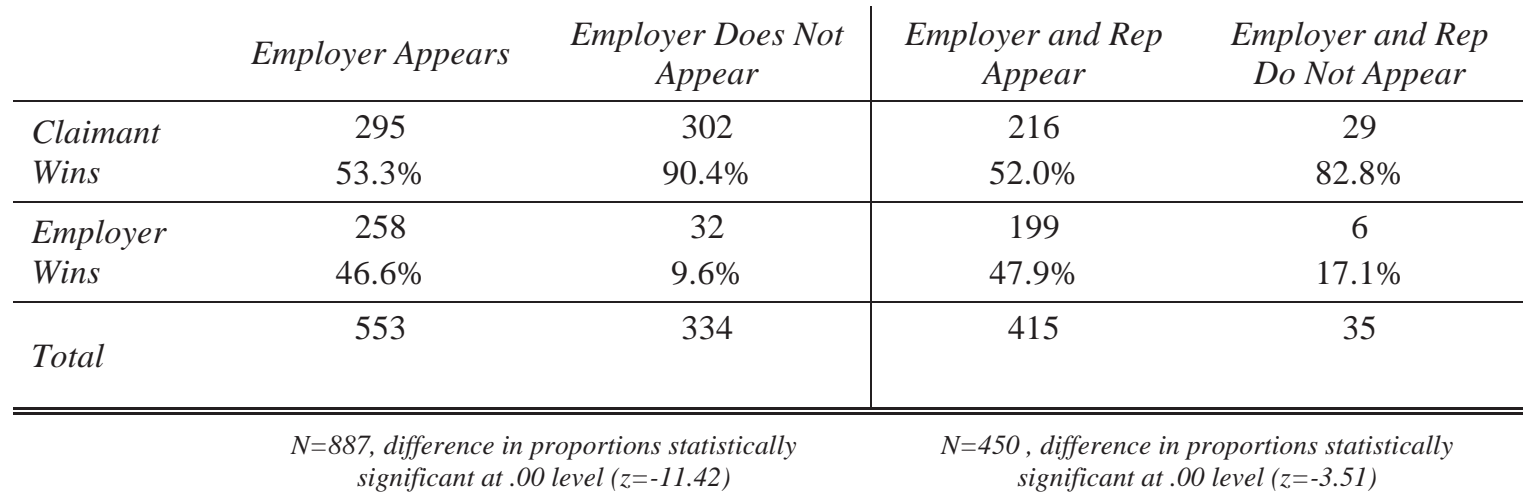

Table 11: Claimant Testimony by Levels of Representation

\begin{tabular}{|c|c|c|c|c|}
\hline & $\begin{array}{c}\text { Claimant } \\
\text { Represented }\end{array}$ & $\begin{array}{c}\text { Claimant } \\
\text { Unrepresented }\end{array}$ & $\begin{array}{c}\text { Claimant } \\
\text { Representative } \\
\text { Appears }\end{array}$ & $\begin{array}{c}\text { Claimant } \\
\text { Representative } \\
\text { Does Not Appear }\end{array}$ \\
\hline Claimant & 214 & 548 & 208 & 6 \\
\hline Testifies & $53.7 \%$ & $39.2 \%$ & $59.2 \%$ & $13.3 \%$ \\
\hline Claimant & 184 & 848 & 143 & 39 \\
\hline $\begin{array}{l}\text { Does Not } \\
\text { Testify }\end{array}$ & $46.2 \%$ & $60.7 \%$ & $40.7 \%$ & $86.6 \%$ \\
\hline \multirow{2}{*}{ Total } & 398 & 1396 & 351 & 45 \\
\hline & $99.9 \%$ & $99.9 \%$ & $99.9 \%$ & $99.9 \%$ \\
\hline
\end{tabular}


Shanahan, Carpenter, \& Mark, Representation in Context

DRAFT - August 11, 2014

Table 12: Employer Testimony by Levels of Representation

\begin{tabular}{lcc|cc} 
& $\begin{array}{c}\text { Employer } \\
\text { Represented }\end{array}$ & $\begin{array}{c}\text { Employer } \\
\text { Unrepresented }\end{array}$ & $\begin{array}{c}\text { Employer } \\
\text { Representative } \\
\text { Appears }\end{array}$ & $\begin{array}{c}\text { Employer } \\
\text { Representative } \\
\text { Does Not Appear }\end{array}$ \\
\hline $\begin{array}{l}\text { Employer } \\
\text { Testifies }\end{array}$ & 512 & 374 & 381 & 123 \\
\hline $\begin{array}{l}\text { Employer } \\
\text { Does Not }\end{array}$ & $57.8 \%$ & $42.2 \%$ & $85.1 \%$ & $29.9 \%$ \\
Testify & 375 & 532 & 67 & 289 \\
\hline Total & $51.4 \%$ & $58.6 \%$ & $14.9 \%$ & $70.2 \%$ \\
\hline \hline & 987 & $100.8 \%$ & 448 & $100.1 \%$ \\
\hline
\end{tabular}

Table 13: Represented Claimant Win Rates Across Claimant Testimony

\begin{tabular}{|c|c|c|c|c|c|c|}
\hline & $\begin{array}{c}\text { Unrepresented } \\
\text { Claimant } \\
\text { Presents } \\
\text { Testimony }\end{array}$ & $\begin{array}{c}\text { Unrepresented } \\
\text { Claimant } \\
\text { Does Not } \\
\text { Present } \\
\text { Testimony }\end{array}$ & $\begin{array}{c}\text { Represented } \\
\text { Claimant } \\
\text { Presents } \\
\text { Testimony }\end{array}$ & $\begin{array}{c}\text { Represented } \\
\text { Claimant } \\
\text { Does Not } \\
\text { Present } \\
\text { Testimony }\end{array}$ & $\begin{array}{c}\text { Claimant } \\
\text { Representative } \\
\text { Appears and } \\
\text { Presents } \\
\text { Testimony }\end{array}$ & $\begin{array}{c}\text { Claimant } \\
\text { Representative } \\
\text { Appears and } \\
\text { Does Not } \\
\text { Present } \\
\text { Testimony }\end{array}$ \\
\hline Claimant & 340 & 526 & 166 & 165 & 162 & 131 \\
\hline Wins & $62.0 \%$ & $62.0 \%$ & $77.5 \%$ & $89.6 \%$ & $77.8 \%$ & $91.6 \%$ \\
\hline Employer & 208 & 322 & 48 & 19 & 46 & 12 \\
\hline Wins & $37.9 \%$ & $37.9 \%$ & $22.4 \%$ & $10.3 \%$ & $22.2 \%$ & $8.4 \%$ \\
\hline \multirow[t]{2}{*}{ Total } & 548 & 848 & 214 & 184 & 207 & 143 \\
\hline & \multicolumn{2}{|c|}{$\begin{array}{c}N=1396, \text { difference in proportions is } \\
\text { not statistically significant }(z=-.01)\end{array}$} & $\begin{array}{l}N=398, \text { differ } \\
\text { statistically si }\end{array}$ & $\begin{array}{l}\text { proportions is } \\
\text { nt at } .001 \text { level } \\
\text { ) }\end{array}$ & \multicolumn{2}{|c|}{$\begin{array}{c}N=351 \text {, difference in proportions is } \\
\text { statistically significant at } .00 \text { level } \\
(z=3.40)\end{array}$} \\
\hline
\end{tabular}

Table 14: Represented Employer Win Rates Across Employer Testimony

\begin{tabular}{|c|c|c|c|c|c|c|}
\hline & $\begin{array}{c}\text { Unrepresented } \\
\text { Employer } \\
\text { Presents } \\
\text { Testimony }\end{array}$ & $\begin{array}{c}\text { Unrepresented } \\
\text { Employer } \\
\text { Does Not } \\
\text { Present } \\
\text { Testimony }\end{array}$ & $\begin{array}{l}\text { Represented } \\
\text { Employer } \\
\text { Presents } \\
\text { Testimony }\end{array}$ & $\begin{array}{c}\text { Represented } \\
\text { Employer } \\
\text { Does Not } \\
\text { Present } \\
\text { Testimony }\end{array}$ & $\begin{array}{c}\text { Employer } \\
\text { Representative } \\
\text { Appears and } \\
\text { Presents } \\
\text { Testimony }\end{array}$ & $\begin{array}{c}\text { Employer } \\
\text { Representative } \\
\text { Appears and } \\
\text { Does Not } \\
\text { Present } \\
\text { Testimony }\end{array}$ \\
\hline Claimant & 219 & 381 & 280 & 316 & 204 & 41 \\
\hline Wins & $58.4 \%$ & $71.6 \%$ & $54.7 \%$ & $84.5 \%$ & $53.3 \%$ & $61.2 \%$ \\
\hline Employer & 156 & 151 & 232 & 58 & 179 & 26 \\
\hline Wins & $41.6 \%$ & $28.4 \%$ & $45.0 \%$ & $15.5 \%$ & $46.7 \%$ & $38.8 \%$ \\
\hline \multirow[t]{2}{*}{ Total } & 375 & 532 & 512 & 374 & 383 & 67 \\
\hline & \multicolumn{2}{|c|}{$\begin{array}{c}N=907 \text {, difference in proportions is } \\
\text { statistically significant at } .00 \text { level }(z=- \\
.4 .14)\end{array}$} & $\begin{array}{r}N=886, \text { differe } \\
\text { statistically signi }\end{array}$ & $\begin{array}{l}\text { proportions is } \\
\text { at } .00 \text { level }(z=-\end{array}$ & \multicolumn{2}{|c|}{$\begin{array}{c}N=450 \text {, difference in proportions is } \\
\text { statistically significant at } .00 \text { level }(z=- \\
1.20)\end{array}$} \\
\hline
\end{tabular}


Shanahan, Carpenter, \& Mark, Representation in Context

DRAFT - August 11, 2014

Table 15: Document Disclosure by Levels of Representation

\begin{tabular}{lcc|cc} 
& $\begin{array}{c}\text { Claimant } \\
\text { Represented }\end{array}$ & $\begin{array}{c}\text { Claimant } \\
\text { Unrepresented }\end{array}$ & $\begin{array}{c}\text { Employer } \\
\text { Represented }\end{array}$ & $\begin{array}{c}\text { Employer } \\
\text { Unrepresented }\end{array}$ \\
\hline Party & 130 & 206 & 587 & 263 \\
Discloses & $32.7 \%$ & $14.8 \%$ & $66.2 \%$ & $28.9 \%$ \\
\hline $\begin{array}{l}\text { Party Does } \\
\text { Not }\end{array}$ & 268 & 1190 & 299 & 644 \\
Disclose & $67.3 \%$ & $85.2 \%$ & $33.7 \%$ & $71.0 \%$ \\
\hline Total & 398 & 1396 & 886 & 907 \\
\hline \hline \multicolumn{4}{c}{$\begin{array}{c}\text { N=1794, difference in proportions is } \\
\text { statistically significant at .O0 level }(z=- \\
\text { 8.07) }\end{array}$} & $\begin{array}{c}\text { N=1794, difference in proportions is } \\
\text { statistically significant at .00 level }(z=- \\
\text { 15.59) }\end{array}$
\end{tabular}

Table 16: Represented Claimant Win Rates Across Document Disclosure

\begin{tabular}{|c|c|c|c|c|c|c|}
\hline & $\begin{array}{c}\text { Unrepresented } \\
\text { Claimant } \\
\text { Discloses }\end{array}$ & $\begin{array}{c}\text { Unrepresented } \\
\text { Claimant Does } \\
\text { Not Disclose }\end{array}$ & $\begin{array}{c}\text { Represented } \\
\text { Claimant } \\
\text { Discloses }\end{array}$ & $\begin{array}{l}\text { Represented } \\
\text { Claimant Does } \\
\text { Not Disclose }\end{array}$ & $\begin{array}{c}\text { Claimant } \\
\text { Representative } \\
\text { Appears and } \\
\text { Discloses }\end{array}$ & $\begin{array}{c}\text { Claimant } \\
\text { Representative } \\
\text { Appears and } \\
\text { Does Not } \\
\text { Disclose }\end{array}$ \\
\hline Claimant & 134 & 732 & 107 & 224 & 95 & 198 \\
\hline Wins & $65.0 \%$ & $61.0 \%$ & $82.3 \%$ & $83.5 \%$ & $83.3 \%$ & $83.5 \%$ \\
\hline Employer & 72 & 458 & 23 & 44 & 19 & 39 \\
\hline Wins & $34.9 \%$ & $38.5 \%$ & $17.7 \%$ & $16.4 \%$ & $16.6 \%$ & $16.4 \%$ \\
\hline Total & 206 & 1190 & 130 & 268 & 114 & 237 \\
\hline
\end{tabular}

Table 17: Represented Employer Win Rates Across Document Disclosure

\begin{tabular}{|c|c|c|c|c|c|c|}
\hline & $\begin{array}{l}\text { Unrepresented } \\
\text { Employer } \\
\text { Discloses }\end{array}$ & $\begin{array}{c}\text { Unrepresented } \\
\text { Employer } \\
\text { Does Not } \\
\text { Disclose }\end{array}$ & $\begin{array}{c}\text { Represented } \\
\text { Employer } \\
\text { Discloses }\end{array}$ & $\begin{array}{c}\text { Represented } \\
\text { Employer } \\
\text { Does Not } \\
\text { Disclose }\end{array}$ & $\begin{array}{c}\text { Employer } \\
\text { Representative } \\
\text { Appears and } \\
\text { Discloses }\end{array}$ & $\begin{array}{l}\text { Employer } \\
\text { Representative } \\
\text { Appears and } \\
\text { Does Not } \\
\text { Disclose }\end{array}$ \\
\hline Claimant & 163 & 437 & 350 & 247 & 214 & 31 \\
\hline Wins & $61.9 \%$ & $67.9 \%$ & $59.6 \%$ & $82.3 \%$ & $52.9 \%$ & $67.3 \%$ \\
\hline Employer & 100 & 207 & 237 & 53 & 190 & 15 \\
\hline Wins & $38.0 \%$ & $32.1 \%$ & $40.3 \%$ & $17.6 \%$ & $47.0 \%$ & $32.6 \%$ \\
\hline \multirow[t]{2}{*}{ Total } & 263 & 644 & 587 & 300 & 404 & 46 \\
\hline & \multicolumn{2}{|c|}{$\begin{array}{c}N=907 \text {, difference in proportions } \\
\text { statistically significant at } .09 \text { level }(z=- \\
\text { 1.69) }\end{array}$} & $\begin{array}{l}N=887 \text {, differ } \\
\text { statistically signi }\end{array}$ & $\begin{array}{l}\text { n proportions } \\
\text { at } .00 \text { level }(z=-\end{array}$ & \multicolumn{2}{|c|}{$\begin{array}{c}N=450 \text {, difference in proportions } \\
\text { statistically significant at } .00 \text { level }(z=- \\
1.86)\end{array}$} \\
\hline
\end{tabular}


Shanahan, Carpenter, \& Mark, Representation in Context

DRAFT - August 11, 2014

Table 18: Document Introduction by Levels of Representation

\begin{tabular}{lcc|cc} 
& $\begin{array}{c}\text { Claimant } \\
\text { Represented }\end{array}$ & $\begin{array}{c}\text { Claimant } \\
\text { Unrepresented }\end{array}$ & $\begin{array}{c}\text { Employer } \\
\text { Represented }\end{array}$ & $\begin{array}{c}\text { Employer } \\
\text { Unrepresented }\end{array}$ \\
\hline Party & 75 & 117 & 465 & 253 \\
Introduces & $18.8 \%$ & $8.4 \%$ & $52.4 \%$ & $27.9 \%$ \\
\hline Party Does & 323 & 1279 & 422 & 654 \\
Not & $81.1 \%$ & $19.6 \%$ & $47.5 \%$ & $72.1 \%$ \\
Introduce & 398 & 1396 & 887 & 907 \\
\hline Total & N=1794, difference in proportions is & N=1794, difference in proportions is \\
& \multicolumn{2}{c}{ statistically significant at .00 level $z=-$} \\
statistically significant at .00 level $(z=-$ & 5.96)
\end{tabular}

Table 19: Represented Claimant Win Rates Across Document Introduction

\begin{tabular}{|c|c|c|c|c|c|c|}
\hline & $\begin{array}{l}\text { Unrepresented } \\
\text { Claimant } \\
\text { Introduces }\end{array}$ & $\begin{array}{l}\text { Unrepresented } \\
\text { Claimant } \\
\text { Does Not } \\
\text { Introduce }\end{array}$ & $\begin{array}{l}\text { Represented } \\
\text { Claimant } \\
\text { Introduces }\end{array}$ & $\begin{array}{l}\text { Represented } \\
\text { Claimant } \\
\text { Does Not } \\
\text { Introduce }\end{array}$ & $\begin{array}{l}\text { Claimant } \\
\text { Representative } \\
\text { Appears and } \\
\text { Introduces }\end{array}$ & $\begin{array}{c}\text { Claimant } \\
\text { Representative } \\
\text { Appears and } \\
\text { Does Not } \\
\text { Introduce }\end{array}$ \\
\hline Claimant & 64 & 802 & 55 & 276 & 54 & 239 \\
\hline Wins & $54.7 \%$ & $62.7 \%$ & $73.3 \%$ & $85.4 \%$ & $73.9 \%$ & $85.9 \%$ \\
\hline Employer & 53 & 477 & 20 & 47 & 19 & 39 \\
\hline Wins & $45.3 \%$ & $37.8 \%$ & $26.6 \%$ & $14.5 \%$ & $26.0 \%$ & $14.0 \%$ \\
\hline \multirow[t]{2}{*}{ Total } & 117 & 1279 & 75 & 323 & 73 & 278 \\
\hline & \multicolumn{2}{|c|}{$\begin{array}{c}N=1396, \text { difference in proportions is } \\
\text { statistically significant at } .08 \text { level } \\
\qquad(z=1.71)\end{array}$} & \multicolumn{2}{|c|}{$\begin{array}{c}N=398 \text {, difference in proportions is } \\
\text { statistically significant at } .01 \text { level } \\
(z=2.52)\end{array}$} & \multicolumn{2}{|c|}{$\begin{array}{c}N=351 \text {, difference in proportions is } \\
\text { statistically significant at } .01 \text { level } \\
\qquad(z=2.45)\end{array}$} \\
\hline
\end{tabular}

Table 20: Represented Employer Win Rates Across Document Introduction

\begin{tabular}{|c|c|c|c|c|c|c|}
\hline & $\begin{array}{l}\text { Unrepresented } \\
\text { Employer } \\
\text { Introduces }\end{array}$ & $\begin{array}{l}\text { Unrepresented } \\
\text { Employer } \\
\text { Does Not } \\
\text { Introduce }\end{array}$ & $\begin{array}{l}\text { Represented } \\
\text { Employer } \\
\text { Introduces }\end{array}$ & $\begin{array}{l}\text { Represented } \\
\text { Employer } \\
\text { Does Not } \\
\text { Introduce }\end{array}$ & $\begin{array}{l}\text { Employer } \\
\text { Representative } \\
\text { Appears and } \\
\text { Introduces }\end{array}$ & $\begin{array}{c}\text { Employer } \\
\text { Representative } \\
\text { Appears and } \\
\text { Does Not } \\
\text { Introduce }\end{array}$ \\
\hline Claimant & 142 & 458 & 250 & 347 & 193 & 52 \\
\hline Wins & $56.1 \%$ & $70.0 \%$ & $53.7 \%$ & $82.2 \%$ & $53.1 \%$ & $59.7 \%$ \\
\hline Employer & 111 & 196 & 215 & 75 & 170 & 35 \\
\hline Wins & $43.8 \%$ & $29.9 \%$ & $46.2 \%$ & $17.8 \%$ & $46.8 \%$ & $40.2 \%$ \\
\hline \multirow[t]{2}{*}{ Total } & 253 & 654 & 465 & 421 & 363 & 87 \\
\hline & \multicolumn{2}{|c|}{$\begin{array}{c}\mathrm{N}=907, \text { difference in proportions is } \\
\text { statistically significant at } .00 \text { level } \\
(z=3.96)\end{array}$} & $\begin{array}{l}=886, \text { differe } \\
\text { statistically signi }\end{array}$ & $\begin{array}{l}\text { proportions is } \\
\text { at } .00 \text { level }(z=-\end{array}$ & \multicolumn{2}{|c|}{$\begin{array}{c}N=450 \text {, difference in proportions is } \\
\text { statistically significant at } 26 \text { level } \\
(z=1.11)\end{array}$} \\
\hline
\end{tabular}


Shanahan, Carpenter, \& Mark, Representation in Context

DRAFT - August 11, 2014

Table 21: Claimant Win Rates Across Combined Procedures

\begin{tabular}{lcc|cc} 
& $\begin{array}{c}\text { Unrepresented } \\
\text { Claimant Uses } \\
\text { Step }\end{array}$ & $\begin{array}{c}\text { Unrepresented } \\
\text { Claimant Does } \\
\text { Not Use Step }\end{array}$ & $\begin{array}{c}\text { Represented } \\
\text { Claimant Uses } \\
\text { Step }\end{array}$ & $\begin{array}{c}\text { Represented } \\
\text { Claimant Does } \\
\text { Not Use Step }\end{array}$ \\
\hline Claimant & 167 & 699 & 134 & 197 \\
Wins & $63.3 \%$ & $61.7 \%$ & $81.2 \%$ & $84.5 \%$ \\
\hline Employer & 97 & 433 & 31 & 36 \\
Wins & $36.7 \%$ & $38.2 \%$ & $18.8 \%$ & $15.5 \%$ \\
\hline Total & 264 & 1132 & 233 & 165 \\
\hline \hline \multicolumn{5}{c}{ N=1396, difference in proportions is not } \\
statistically significant $(z=-.45)$ & $\begin{array}{c}\text { N=398, difference in proportions is not } \\
\text { statistically significant }(z=.88)\end{array}$
\end{tabular}

Table 22: Employer Win Rates Across Combined Procedures

\begin{tabular}{|c|c|c|c|c|}
\hline & $\begin{array}{l}\text { Unrepresented } \\
\text { Employer Uses } \\
\quad \text { Step }\end{array}$ & $\begin{array}{l}\text { Unrepresented } \\
\text { Employer Does } \\
\text { Not Use Step }\end{array}$ & $\begin{array}{l}\text { Represented } \\
\text { Employer Uses } \\
\text { Step }\end{array}$ & $\begin{array}{l}\text { Represented } \\
\text { Employer Does } \\
\text { Not Use Step }\end{array}$ \\
\hline $\begin{array}{l}\text { Claimant } \\
\text { Wins }\end{array}$ & $\begin{array}{c}200 \\
60.4 \%\end{array}$ & $\begin{array}{c}400 \\
69.4 \%\end{array}$ & $\begin{array}{c}400 \\
60.2 \%\end{array}$ & $\begin{array}{c}196 \\
88.3 \%\end{array}$ \\
\hline $\begin{array}{l}\text { Employer } \\
\text { Wins }\end{array}$ & $\begin{array}{c}131 \\
39.5 \%\end{array}$ & $\begin{array}{c}176 \\
30.6 \%\end{array}$ & $\begin{array}{c}264 \\
39.8 \%\end{array}$ & $\begin{array}{c}26 \\
11.7 \%\end{array}$ \\
\hline Total & 331 & 576 & 664 & 222 \\
\hline & \multicolumn{2}{|c|}{$\begin{array}{c}N=907, \text { difference in proportions } \\
\text { statistically significant at } .005 \text { level }(z=- \\
2.76)\end{array}$} & \multicolumn{2}{|c|}{$\begin{array}{c}N=886 \text {, difference in proportions } \\
\text { statistically significant at } .00 \text { level }(z=- \\
7.71)\end{array}$} \\
\hline
\end{tabular}

